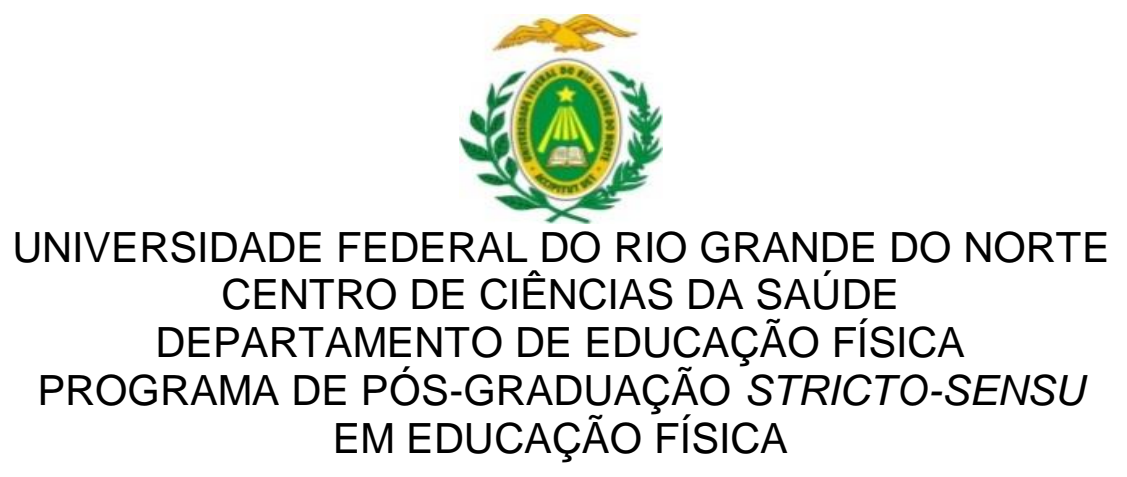

EM EDUCAÇÃO FÍSICA

\title{
EFEITOS DE SESSÕES DE PSICOMOTRICIDADE RELACIONAL SOBRE O PERFIL DAS HABILIDADES MOTORAS E CONTROLE POSTURAL EM INDIVÍDUO COM TRANSTORNO DO ESPECTRO AUTISTA
}

Ana Charline Dantas Ferreira 
EFEITOS DE SESSÕES DE PSICOMOTRICIDADE RELACIONAL SOBRE O PERFIL DAS HABILIDADES MOTORAS E CONTROLE POSTURAL EM INDIVÍDUO COM TRANSTORNO DO ESPECTRO AUTISTA

ANA CHARLINE DANTAS FERREIRA

Dissertação apresentada ao Programa de Pós-Graduação em Educação Física da Universidade Federal do Rio Grande do Norte, como requisito parcial para obtenção do grau de Mestre em Educação Física.

Orientador: Prof. Dr. Jônatas de França Barros 
Catalogação da Publicação na Fonte

Universidade Federal do Rio Grande do Norte - Sistema de Bibliotecas Biblioteca Central Zila Mamede / Setor de Informação e Referência

Ferreira, Ana Charline Dantas.

Efeitos de sessões de psicomotricidade relacional sobre o perfil das habilidades motoras e controle postural em indivíduo com transtorno do espectro autista / Ana Charline Dantas Ferreira. - 2016.

93 f. : il.

Dissertação (Mestrado) - Universidade Federal do Rio Grande do Norte, Centro de Ciências da Saúde, Programa de Pós-Graduação em Educação Física. Natal, RN, 2016.

Orientador: Prof. Dr. Jônatas de França Barros.

1. Autismo - Dissertação. 2. Prática pedagógica - Dissertação. 3. Psicomotricidade relacional - Dissertação. 4. Desenvolvimento motor Dissertação. 5. Déficits motores - Dissertação. 6. Brincar - Dissertação. I. Barros, Jônatas de França. II. Título. 


\section{EFEITOS DE SESSÕES DE PSICOMOTRICIDADE RELACIONAL SOBRE O PERFIL DAS HABILIDADES MOTORAS E CONTROLE POSTURAL EM INDIVÍDUO COM TRANSTORNO DO ESPECTRO AUTISTA}

Dissertação apresentada ao Programa de Pós-Graduação em Educação Física da Universidade Federal do Rio Grande do Norte, como requisito parcial para obtenção do título de Mestre em Educação Física.

Orientador: Dr. Jônatas de França Barros

COMISSÃO JULGADORA

Prof. Dr. Jônatas de França Barros

Membro Interno - UFRN (Presidente)

Profa. Dr. José Pereira de Melo

Membro Titular Interno - UFRN

Profa. Dr. Francisco Rosa Neto

Membro Titular Externo - UDESC

Prof. Dra. Margareth de Vasconcelos Monteiro Membro Titular Externo - UFRN

Prof. Dr. Daniel Bezerra de Brito

Membro Suplente Externo - UERN

Aprovado em: 25 de agosto de 2016 . 


\section{AGRADECIMENTOS}

Agradeço a Deus, por me permitir a vida e uma caminhada cheia de obstáculos a serem ultrapassados. Acredito que os momentos difíceis são os de maiores aprendizados. Grata pelos milagres e orgulhosa por cada cicatriz carregada.

A minha família, fonte de minha força e confiança em que TUDO DÁ CERTO, meus agradecimentos e todo o meu amor.

Aos amigos que sempre tive e aos que ganhei, agradeço pelo apoio e crença incondicional. Certamente isto ofertou em mim, esperança em dias melhores. Devo carinhosamente agradecer ao "Chico Holanda", meu parceiro de estudo, aquele que confabulava comigo por horas ao telefone, desde "nossas ideias acadêmicas" até as várias bobagens, motivos de muitas gargalhadas. Sou grata por tê-lo em minha vida.

Sou eternamente agradecida ao Professor Jônatas de França Barros, o qual me aceitando como orientanda, oportunizou a escrita de mais uma página de minha história profissional. Agradeço pela oportunidade de crescer como profissional e também como pessoa, pois os erros e as fragilidades apontadas me fazem sedenta por mais aprendizado. Obrigada pela orientação nessa trajetória.

Grata ao professor Patrick Ramon Stafin Coquerel, por dividir seus conhecimentos e executar a obra com tanto amor. Minha eterna admiração e amizade.

Agradeço à professora Margareth de Vasconcelos Monteiro, pelo apoio e ajuda. Sua simplicidade e seriedade norteia o rumo da minha vida profissional.

Agradeço ao professor Ewerton Dantas Cortes Neto, que me acompanha e me apoia desde a graduação. Sua amizade é deveras valiosa.

Aos integrantes da base de pesquisa GEPAEF que tanto me ajuda a explorar o universo da Educação Física e do movimento humano, meus agradecimentos.

Agradeço ao CAPSi, que acreditou no nosso trabalho e as crianças que se dispuseram a fazer os testes e a viver com alegria nas terças-feiras da Psicomotricidade Relacional. Todas me ajudaram no construir do conhecimento e no despertar para um olhar de águia nesse universo tão rico, enigmático e cheio de nuances Autista.

Certa de que fui oportunizada por um aprendizado acadêmico e um aprendizado de vida, deixo meus sinceros agradecimentos a todos que cruzaram meu caminho. 
Até os jovens se cansam E ficam exaustos,

E os moços tropeçam e caem; mas aqueles que esperam no Senhor Renovam as suas forças. Voam alto como águias; Correm e não ficam exaustos, Andam e não se cansam. (Isaías 40:30-31) 
SUMÁRIO

1 INTRODUÇÃO

1.1 FUNDAMENTAÇÃO DO PROBLEMA E SUA IMPORTÂNCIA .......................1

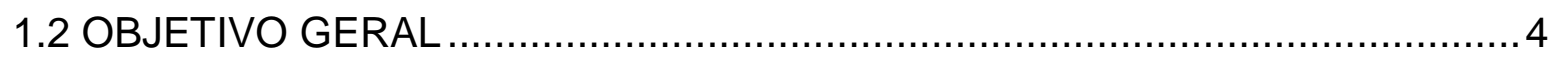

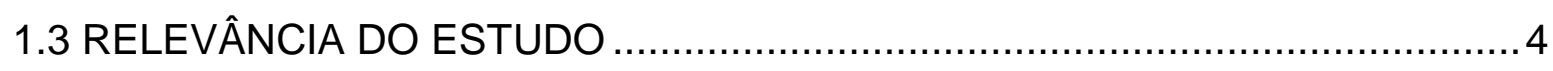

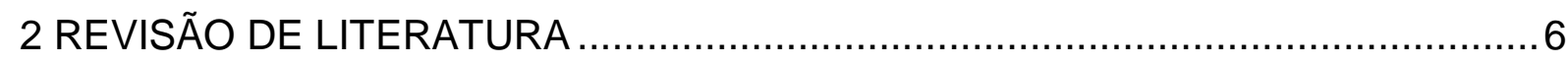

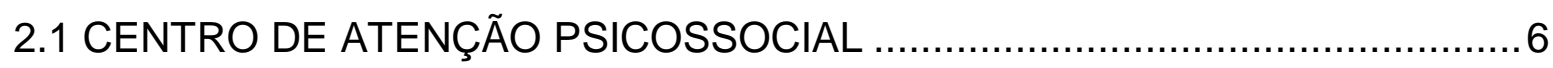

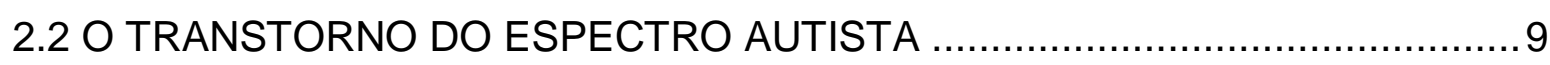

2.2.1 Histórico e Conceito do Transtorno do Espectro Autista .............................. 9

2.2.2 Intervenções no Transtorno do Espectro Autista ...................................... 12

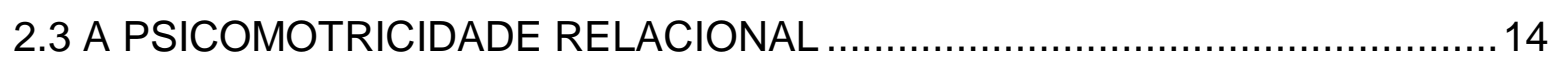

2.4 HABILIDADES MOTORAS E SEU DESENVOLVIMENTO ...........................18

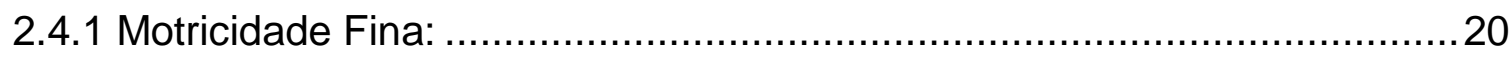

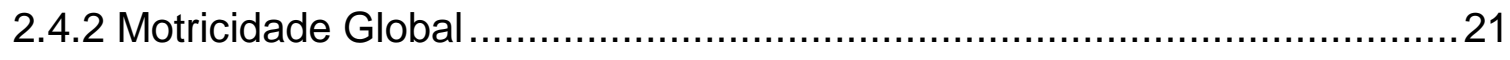

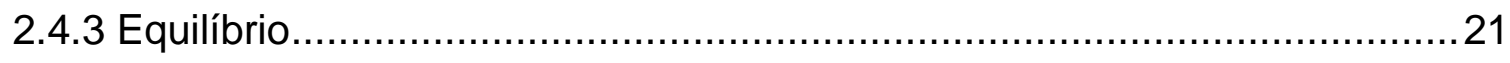

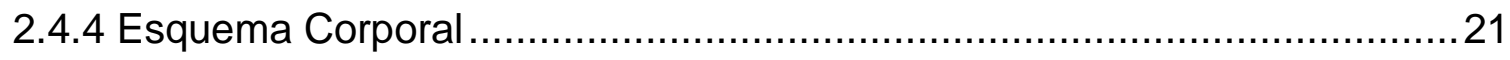

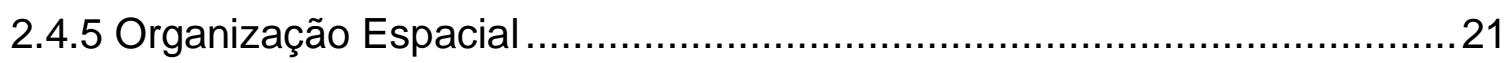

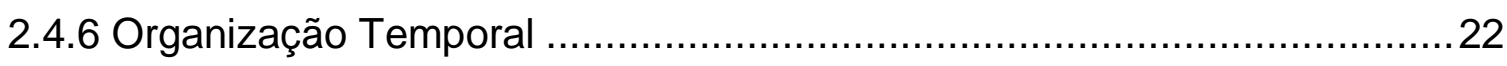

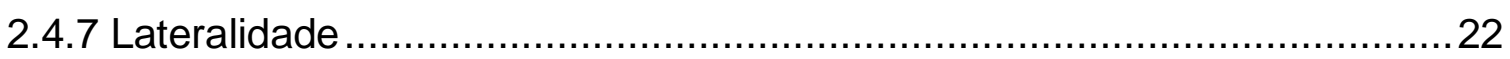

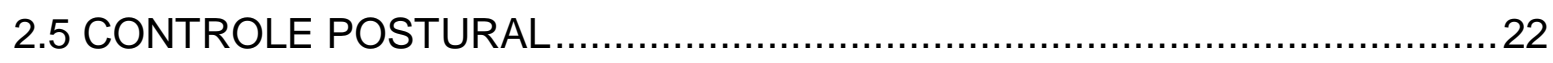

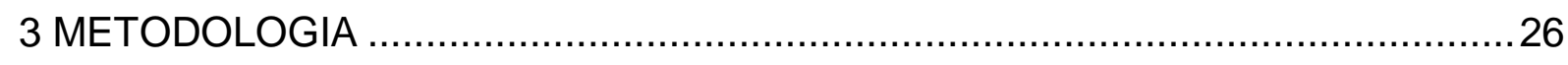

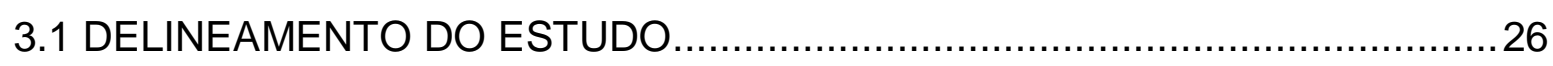

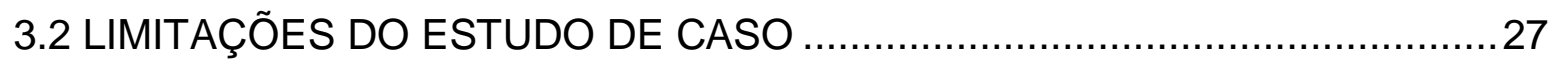

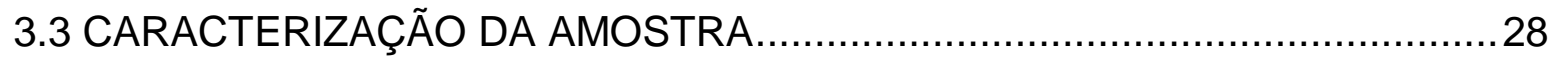

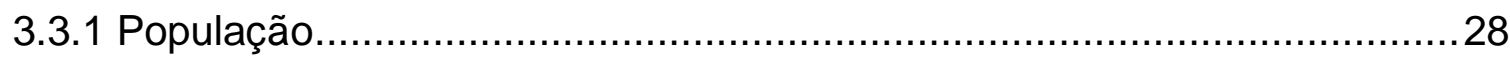

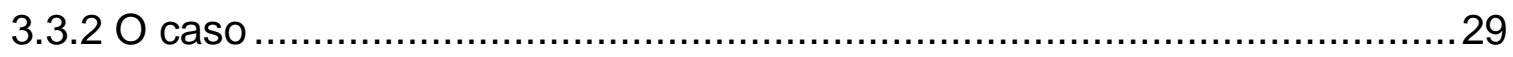

3.4 APRECIAÇÃO PELO COMITÊ DE ÉTICA EM PESQUISA ...........................31 


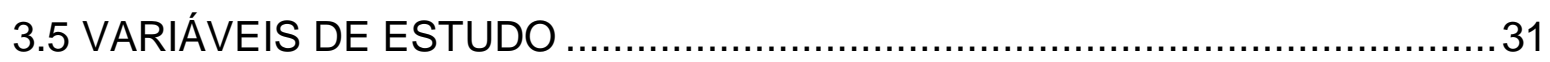

3.5.1 Variável independente: Psicomotricidade Relacional.................................31

3.5.2 Variáveis dependentes: Habilidades Motoras e Controle Postural. ............31

3.6 PROCEDIMENTOS E INSTRUMENTOS DE COLETAS …..............................31

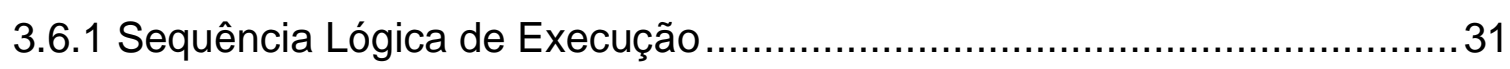

3.6.2 Escala de Desenvolvimento Motor (EDM) ........................................... 32

3.6.3 Posturografia em Plataforma de Força .................................................. 34

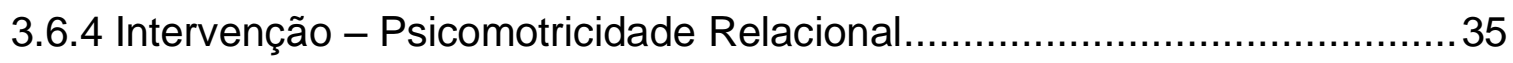

3.6.5 Análise de vídeo das sessões baseada no Teste Do Desenvolvimento Motor Amplo - Segunda Edição - TGMD-2 (ULRICH, 2000) .................................... 38

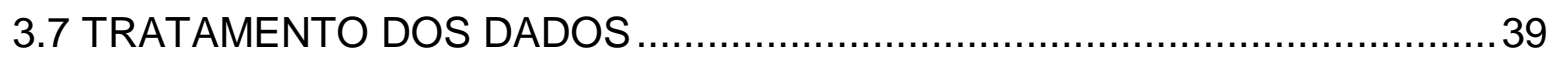

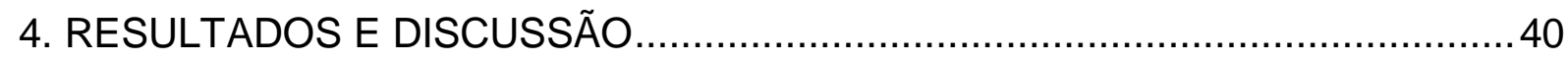

4.1 AVALIAÇÃO DAS HABILIDADES MOTORAS ............................................. 40

4.2 AVALIAÇÃO DO CONTROLE POSTURAL.................................................. 49

4.3 ANÁLISE DE HABILIDADES MOTORAS NO SETTING DA PSICOMOTRICIDADE RELACIONAL ……............................................... 51

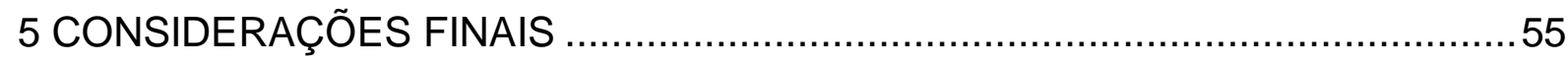

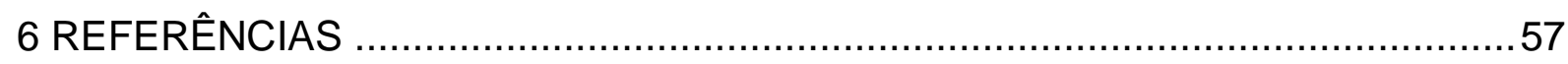

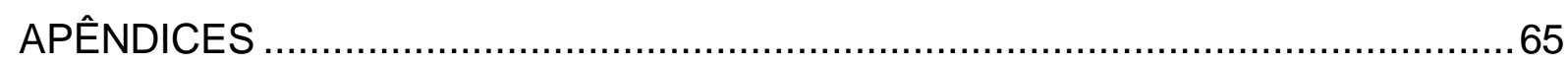

APÊNDICE A - DECLARAÇÃO DE CIÊNCIA INSTITUCIONAL ..........................65

APÊNDICE B - TERMO DE CONCENTIMENTO LIVRE E ESCLARECIDO ........66

APÊNDICE C - PLANOS DE AULA - PSICOMOTRICIDADE RELACIONAL ......67

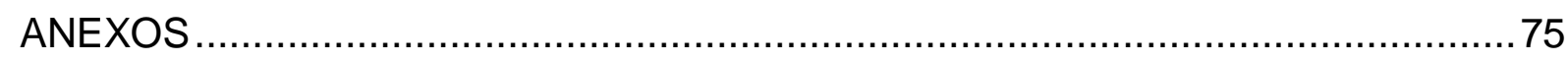

ANEXO A - APRECIAÇÃO PELO COMITÊ DE ÉTICA EM PESQUISA ................75 


\section{LISTA DE TABELAS}

Tabela 1 - Amplitude média de Oscilação do Centro de Pressão nas direções ap e ml, Deslocamento do Centro de Pressão Total e Delta Percentual 38 


\section{LISTA DE FIGURAS}

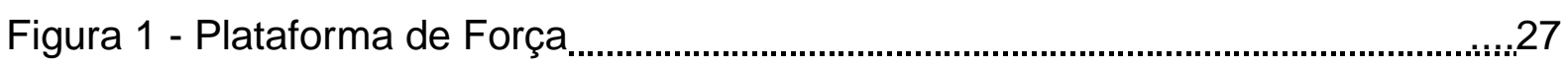

Figura 2 - Imagem do Setting ..................................................................................... 28

Figura 3 - Ritual de Entrada ................................................................................. 28

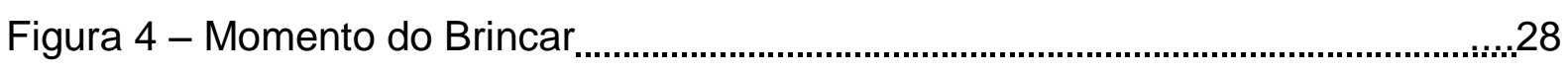

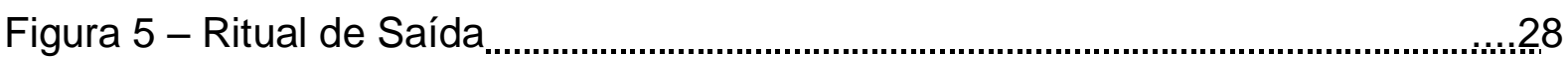

Figura 6 - Gráfico da Idade Cronológica, Idade Motora Geral, Idade Negativa e

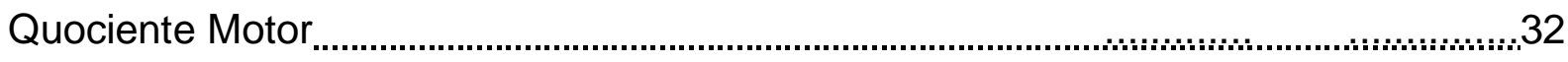

Figura 7 - Gráfico das Idades Motoras em cada Habilidade.........................................34

Figura 8 - Gráfico dos Quocientes Motores em cada Habilidade Motora.................... 35 


\section{LISTA DE QUADROS}

Quadro 01 - Descrição das sessões de Psicomotricidade Relacional.......................29

Quadro 02 - Desenhos da Criança e suas Descrições............................................45 
LISTA DE SIGLAS, ABREVIAÇÕES E SÍMBOLOS

$(\Delta \%)$

ABA

CID-10

$\mathrm{CP}$

AmCPap

AmCPml

CV

DIR

DSM-5

EDM

IC

IM

IM1

IM2

IM3

IM4

IM5

IM6

IMG

IN

PBS

PECS

PR

QM

QMG

SIT

SV

TEA

TEACCH
Delta Percentual de Variação

Applied Behavior Analysis

Classificação Internacional de Doenças - 10

Centro de Pressão

Amplitude média de Oscilação do Centro de Pressão

Anteroposterior

Amplitude média de Oscilação do Centro de Pressão Médio-

Lateral

Com visão

Desenvolvimento Diferencial Individual e Relacional

Manual Estatístico e Diagnóstico de Transtornos Mentais

Escala de Desenvolvimento Motor

Idade Cronológica

Idade Motora

Idade Motora da Motricidade Fina

Idade Motora da Motricidade Global

Idade Motora do Equilíbrio

Idade Motora do Esquema Corporal

Idade Motora da Organização Espacial

Idade Motora da Organização Temporal

Idade Motora Geral

Idade Negativa

Positive Behaviour Support Programs

Picture Exchange Communication System

Psicomotricidade Relacional

Quociente Motor

Quociente Motor Geral

Sensory Integration Therapy

Sem Visão

Transtorno do Espectro Autista

Treatment and Education of Autistic and Related

Communication Handicapped Children 


\section{RESUMO}

\section{EFEITOS DE SESSÕES DE PSICOMOTRICIDADE RELACIONAL SOBRE O PERFIL DAS HABILIDADES MOTORAS E CONTROLE POSTURAL EM INDIVIDUO COM TRANSTORNO DO ESPECTRO AUTISTA}

\section{Autora: Ana Charline Dantas Ferreira}

\section{Orientador: Jônatas de França Barros}

O Transtorno do Espectro Autista é considerado um transtorno do neurodesenvolvimento e do comportamento que se caracteriza pela dificuldade na interação e comunicação social com comportamentos repetitivos do indivíduo, podendo estar associado a outras síndromes com causas múltiplas. Indivíduos com Transtorno do Espectro Autista possuem padrão de desenvolvimento humano irregular e déficits no desenvolvimento motor. A Psicomotricidade Relacional é uma prática pedagógica, dedicada à movimentação corporal espontânea e ao brincar que utiliza o imaginário e o simbólico, o emocional e o afetivo, dispondo à criança e ao adulto diferentes objetos nos quais observa-se a interação entre eles. OBJETIVO: Avaliar os efeitos de sessões de Psicomotricidade Relacional sobre o perfil das habilidades motoras e o controle postural em indivíduos com Transtorno do Espectro Autista. METODOLOGIA: Trata-se de uma pesquisa exploratória-descritiva, com delineamento de um estudo de caso avaliativo. Acompanhou-se um indivíduo com 5 anos de idade, diagnosticado com Transtorno do Espectro Autista. Para coleta de dados pré e pós-testes foram utilizadas a Escala de Desenvolvimento Motor (EDM) e Posturografia em Plataforma de Força. Foram aplicadas 8 sessões de Psicomotricidade Relacional com crianças com o Transtorno do Espectro Autista, sendo uma por semana com duração de 60 minutos, registradas por meio de relatório construído pelos professores da sessão. Em seguida, o indivíduo foi reavaliado. Os resultados foram analisados de forma descritiva (pré e pós), sendo o da EDM por sua própria escala e a Posturografia pelo delta percentual de variação $(\Delta \%)$. RESULTADOS: As sessões de Psicomotricidade Relacional promoveram ao indivíduo uma vivência corporal que permitiu uma maior movimentação e interação com os professores, e com as demais crianças na sessão, modificando o perfil das habilidades motoras e do controle postural, fato que foi demonstrado através dos resultados positivos da Escala de Desenvolvimento Motor e na diminuição da oscilação postural. Avanços foram encontrados nos testes da Escala de Desenvolvimento Motor nas áreas da motricidade fina, motricidade global, esquema corporal e organização temporal, não apresentando diferença na área do equilíbrio e apresentando diminuição dos escores na área da organização espacial. O quociente motor geral (QMG) passou de uma classificação muito inferior (QMG: 61,5) para normal baixo (QMG: 82,4) modificando a classificação de risco grave para risco leve no desenvolvimento motor. A Posturografia apontou escores de diminuição nas oscilações do centro de pressão nas variáveis analisadas. CONSIDERAÇÕES FINAIS: A partir de uma abordagem espontânea do brincar, na qual o indivíduo é estimulado a entrar numa movimentação e vivência corporal, percebeu-se que as sessões de Psicomotricidade Relacional surtiram efeitos positivos sobre o perfil das habilidades motoras e controle postural do indivíduo com Transtorno do Espectro Autista avaliado no presente estudo. 
Palavras-Chave: Autismo; Desenvolvimento motor; Déficits motores; Psicomotricidade Relacional; Brincar. 


\title{
ABSTRACT \\ THE EFFECTS OF RELATIONAL PSYCHOMOTRICITY SESSIONS ON THE PROFILE OF MOTOR SKILLS AND POSTURAL CONTROL IN INDIVIDUAL WITH AUTISM SPECTRUM DISORDER
}

\author{
Authoress: Ana Charline Dantas Ferreira \\ Mentor: Jônatas de França Barros
}

The Autism Spectrum Disorder is a behavior and neurodevelopment disorder which characterized by trouble in the interaction and social communication, and subject's repetitive behaviors, which may be associated with others disorders with multiple causes. Subjects with Autism Spectrum Disorder have irregular human development and deficit in motor development. Relational Psychomotricity (RP) is a pedagogical practice, dedicated to spontaneous body movement and play using the imaginary and the symbolic, the emotional and the affective, providing to child and adult different objects in which we can observe the interaction between them. PURPOSE: Evaluate the effects of Relational Psychomotricity sessions on motor skills profile and postural control in individuals with Autism Spectrum Disorder. METODOLOGY: This is a descriptive exploratory research, with design of an evaluative case study. Was accompanied a 5 years individual diagnosed with Autism Spectrum Disorder. To collect pre and post-test data were used the Motor Development Scale (MDS) and Posturography in force platform; were applied 8 sessions of Relational Psychomotricity with child with Autism Spectrum Disorder, with one session per week lasting 60 minutes each session, recorded through report observed by teachers who worked in the session. Subsequently, the individual was reassessed. The results were analyzed descriptively (pre and post), with the MDS by its scale and the Posturography by the percentage change delta $(\Delta \%)$. RESULTS: The Relational Psychomotricity sessions gave to the individual a corporal experience, which allowed a movement and interaction with teachers and with other children, changing the profile of motor skills and postural control, demonstrated by the positive results of MDS and decrease in postural sway. Advances were found in the MDS tests in the areas of fine motor skills, overall motor skills, body image and temporal organization, with no significant difference in the area of balance and showing decreased scores in the area of spatial organization. The total motor quotient (TMQ) was changed from much lower rating (TMQ: 61.5) to low normal (TMQ: 82.4), modifying the severe risk rating for slight risk in motor development. Posturography pointed decrease of scores in the oscillations of center of pressure in variables. FINAL CONSIDERATIONS: From a spontaneous approach to the play, in which the individual is encouraged to enter into a movement and corporal experience, it was realized that the RP sessions had positive effects on the profile of motor skills and postural control of individual with Autism Spectrum Disorder evaluated in this study.

Keywords: Autism; motor development; motor deficits; relational psychomotricity; play. 


\section{INTRODUÇÃO}

\subsection{FUNDAMENTAÇÃO DO PROBLEMA E SUA IMPORTÂNCIA}

Considerado como um transtorno do neurodesenvolvimento e do comportamento, o Transtorno do Espectro Autista (TEA) caracteriza-se pelas dificuldades na interação e comunicação social e comportamentos repetitivos do indivíduo (OMS, 2008; FALKENBACH; DIESEL; OLIVEIRA, 2010; APA, 2014), podendo estar associado a outras síndromes com causas múltiplas (LAl; LOMBARDO; BARON-COHEN, 2015). Sua prevalência é de 1 indivíduo com Transtorno do Espectro Autista para cada 68 (ONU, 2016), o que nos leva a apontar que cerca de $1 \%$ da população mundial está dentro do espectro; essa prevalência tem aumentado desde que foi descoberta há 70 anos, provavelmente, em função do aumento das pesquisas, da sistematização dos instrumentos avaliativos, bem como das intervenções baseadas em evidências (LAI, LOMBARDO E BARON-COHEN, 2014).

Neste sentido, os Indivíduos com Transtorno do Espectro Autista possuem padrão de desenvolvimento humano irregular (MATSON, 2010) e déficits no desenvolvimento motor (LARSON et al 2008; FOURNIER et al, 2010; CALHOUN; LONGWORTH; CHESTE, 2010). Devemos lembrar que o desenvolvimento humano é subdividido em três domínios do comportamento: psicomotor (comportamento motor), cognitivo (comportamento intelectual) e afetivo (comportamento sócio emocional) que se inter-relacionam e, desse modo, o desenvolvimento psicomotor caracteriza-se como a mudança contínua do comportamento motor durante o ciclo da vida, derivada da interação entre a biologia do indivíduo, as exigências da tarefa motora e as condições do ambiente (GALLAHUE; OZMUN; GOODWAY, 2013).

Entretanto, a habilidade motora é a ação ou a tarefa de movimento voluntário que demanda o uso do corpo e/ou de suas partes para atingir um objetivo, e se classifica quanto à função do movimento como: tarefas de estabilidade (mantém uma orientação corporal estável), tarefas de locomoção (transporte do corpo de um ponto a outro) e tarefas de manipulação de objetos (transmite ou recebe força de um objeto) (MAGILL, 2000; GALLAHUE; OZMUN; GOODWAY, 2013). 
Crianças com Transtorno do Espectro Autista possuem déficits nas habilidades motoras, demonstrados através das dificuldades motoras finas e das globais, as quais estão positivamente correlacionadas com atrasos no processamento sensorial, na escrita, na comunicação e nos prejuízos sociais (LIU, 2013).

Observa-se que o baixo desempenho motor vai ao encontro dos problemas de controle postural presentes nas crianças com Transtorno do Espectro Autista, uma vez que estas demonstram maiores dificuldades motoras e posturais do que as crianças com desenvolvimento típico (LARSON et al 2008; MATSON, 2010; FOURNIER et al, 2010; CALHOUN, LONGWORTH E CHESTE, 2010; KOHEN-RAZ; VOLKMAN; COHEN, 1992; MOLLOY, DIETRICH; BHATTACHARYA, 2003; MINSHEW et al, 2004; CHANG et al, 2010; FOURNIER et al, 2010; MACHE; TOD, 2016). Em um estudo comparativo, Memari et al (2013) apontou uma diferença na oscilação postural em crianças dentro do Transtorno.

Da mesma forma, Fournier et al (2010) em seu estudo sobre controle postural, encontrou uma maior oscilação do centro de pressão em posição estática das crianças com Transtorno do Espectro Autista frente às crianças com desenvolvimento típico e escores parecidos com a avaliação da marcha, porém notou-se uma variação de adaptação muscular diferente para o grupo de crianças com o Transtorno do Espectro Autista.

O controle postural requer uma interação completa entre o sistema neural e musculoesquelético e relaciona-se com a biomecânica dos segmentos corporais. A ação do controle postural é resultante da interação entre o indivíduo, a tarefa e o ambiente. Importante para a área motora, o controle postural exige o domínio da posição do corpo no espaço com o propósito de proporcionar orientação e estabilidade (SHUMWAY-COOK; WOOLLACOTT, 2010; TRAVERS, 2013).

Déficits funcionais identificados entre os indivíduos e a inadequação de suas habilidades psicomotoras implicam em impactos na aprendizagem e na qualidade de suas interações cognitivas e socioafetivas (MANSUR; MARCON, 2006; NUNES, 2014). A movimentação corporal no ambiente baseada em atividades envolvendo o brincar tem sido aplicado como intervenção para crianças com Transtorno do Espectro Autista. Rosa Neto et al (2013) em um estudo de caso, compara os escores pré e pós de uma intervenção através de atividades lúdicas. Os resultados apontam melhores escores pós-intervenção da Escala de Desenvolvimento Motor de um indivíduo com 
Transtorno do Espectro Autista em quatro das seis áreas avaliadas da escala. O que vem a corroborar com o estudo de caso feito por Falkenbach (2010) no qual foram aplicadas sessões de Psicomotricidade Relacional, estimulando o brincar espontâneo e o jogo simbólico. O estudo apontou melhores escores do desenvolvimento do indivíduo com Transtorno do Espectro Autista, principalmente no aumento da movimentação corporal, na iniciativa do brincar e no relacionamento socioafetivo.

A movimentação corporal, juntamente com sua adaptação, é vital e importante para o estímulo do desenvolvimento motor durante a infância, visto que através de sua estimulação é possível melhorar as habilidades motoras (ROSA NETO, 2013). Mediante isso, a Psicomotricidade engloba o movimento do corpo, a relação com o meio e a capacidade psíquica; a interação destes elementos resulta numa vivência da atividade física como um meio rico e saudável para a relação integrada mente/corpo da criança (ALMEIDA, 2014). Assim, a estimulação psicomotora possibilita um melhor desenvolvimento motor (ALVES, 2007).

Sendo uma vertente da Psicomotricidade, a Psicomotricidade Relacional objetiva investir no desenvolvimento da criança através do brincar e dos jogos simbólicos (LAPIERRE, 2010). Encontra no corpo a significância afetiva para o seu movimento (GLASENAPP, 2012). A Psicomotricidade Relacional propõe um espaço para que a criança vivencie o seu potencial e criatividade de forma espontânea e livre, buscando o contato a partir do seu próprio corpo, do objeto, do espaço e do outro (LAPIERRE e AUCOUTURIER, 2004). A prática do brincar quando vivenciada pelas crianças em situações espontâneas são organizadas de forma própria com predomínio do jogo simbólico (ASSIS et. al., 2015).

Sabe-se que as brincadeiras e jogos espontâneos são inerentes ao universo das crianças e estimulam o desenvolvimento psicomotor e afetivo (VIEIRA; BATISTA; LAPIERRE, 2005; KISHIMOTO, 2010). Indivíduos com Transtorno do Espectro Autista têm desenvolvimento atípico e déficits motores frente aos indivíduos com desenvolvimento típico (FOURNIER et al, 2010). Verifica-se a necessidade de novos estudos visando mais conhecimento acerca do desenvolvimento motor, do comportamento no controle postural e de intervenções que estimulem o indivíduo que se encontra dentro do Transtorno do Espectro Autista, uma vez que poucas intervenções são desenvolvidas para o desenvolvimento de habilidades motoras nesta população, havendo assim, a necessidade de intervenções para que essas 
habilidades sejam melhoradas, a fim de que haja uma maior participação do autista nas demais modalidades esportivas e práticas de atividade física (LIU, 2013).

Portanto, delimita-se o problema de pesquisa deste estudo: Qual a influência das sessões de Psicomotricidade Relacional sobre o perfil das habilidades motoras e controle postural em indivíduo com Transtorno do Espectro Autista?

\subsection{OBJETIVO GERAL}

Avaliar os efeitos de sessões de Psicomotricidade Relacional sobre o perfil das habilidades motoras e o controle postural em indivíduo com Transtorno do Espectro Autista.

\subsection{RELEVÂNCIA DO ESTUDO}

As pesquisas com temas relacionados ao Transtorno do Espectro Autista desde sua descoberta na década de 40 são crescentes (LAI; LOMBARDO; BARON-COHEN, 2014). A etiologia do autismo ainda é muito enigmática e a busca por mais informações e detalhes de suas características se faz necessária.

Intervenções quando aplicadas de forma precoce tendem a minimizar os impactos negativos das características do Transtorno do Espectro Autista, o que demonstra a importância do diagnóstico, uma vez que já se discute a importância da inclusão da deficiência motora como parte dos critérios diagnósticos (LIU, 2013). Porém, este raramente é evidenciado antes dos três anos de idade e pouco se sabe sobre quando e como o desenvolvimento normal é interrompido nos primeiros anos de vida (LANDA; MAYER, 2006).

Os estudos apresentados demonstram que as intervenções aplicadas nos indivíduos com Transtorno do Espectro Autista respondem sobre um comportamento motor deficitário frente aos indivíduos ditos "normais", avaliam melhores escores frente a uma atividade motora espontânea baseada no brincar, mas não demonstram se a intervenção é capaz de modificar o comportamento motor. Visto isso, as informações coletadas neste projeto buscaram dar respostas frente ao problema de pesquisa, as quais servirão para auxiliar os profissionais quanto à prática da intervenção. 
A participação no Grupo de Estudo em Ludomotricidade (GEL) da UFRN, que contempla os estudos específicos da intervenção lúdica no homem, bem como nos indivíduos das populações especiais, despertou um olhar sobre o Transtorno do Espectro Autista. Neste sentido, o presente estudo é, também, resultado de um trabalho desenvolvido no GEL, uma vez que são os resultados das práticas de intervenção aplicadas à população em estudo, o que vem reforçar a importância da pesquisa desenvolvida junto a UFRN e os incentivos aos grupos de estudos que fomenta a pesquisa.

A pesquisa contribui para um melhor conhecimento sobre uma intervenção que visa à inclusão de indivíduos que na maioria das vezes encontram-se à margem, quando se refere às práticas corporais necessárias a todos e que se estende aos indivíduos com Transtorno do Espectro Autista existentes na sociedade.

Desse modo, a Psicomotricidade Relacional apresenta-se como uma oportunidade de estimular o desenvolvimento holístico/integral do ser e promover inclusão social.

Com isso, avalia-se importante pesquisar sobre as influências das sessões de Psicomotricidade Relacional sobre o perfil das habilidades motoras e o controle postural em indivíduos com Transtorno do Espectro Autista, uma vez que essas variáveis são relevantes para as práticas das atividades diárias do indivíduo, bem como nas diversas práticas corporais sociais. 


\title{
2 REVISÃO DE LITERATURA
}

\subsection{CENTRO DE ATENÇÃO PSICOSSOCIAL}

Em março de 1986 foi inaugurado o primeiro Centro de Atenção Psicossocial (CAPS) do Brasil na cidade de São Paulo, a partir de reivindicações de trabalhadores de saúde mental num movimento social por melhorias na assistência aos portadores de transtornos metais no Brasil. Este fato culminou na implementação e consolidação do CAPS em vários municípios do país, como um dispositivo eficaz na mudança do modelo assistencial e minimização das internações de pacientes que necessitavam de assistência intermediária entre o regime ambulatorial e a internação hospitalar (BRASIL, 2004).

\section{Mas o que é o CAPS?}

CAPS é um serviço de saúde aberto à comunidade regulamentado pela Portaria $\mathrm{n}^{\circ}$ 336, de 19 de fevereiro de 2002 e que integra a rede do Sistema Único de Saúde, o SUS. É um dispositivo com o propósito de substituir os Hospitais Psiquiátricos com assistência multiprofissional focada na atenção comunitária, dirigido ao indivíduo com sofrimento ou transtorno psíquico em geral, incluindo aquelas com necessidades decorrentes do uso de crack, álcool e outras drogas, a qual visa a assistência clínica multidisciplinar e inclusão social (BRASIL, 2011).

\begin{abstract}
Considerando os objetivos dos CAPS e as práticas a serem desenvolvidas, 0 "espaço CAPS" e os espaços do CAPS assumem fundamental relevância: trata-se de projetar serviços públicos de saúde, substitutivos ao modelo asilar, de referência nos territórios, comunitários, de livre acesso e local de trocas sociais. Em síntese: serviços de atenção psicossocial do SUS, espaços de cuidar e apoiar pessoas com experiências do sofrimento e, ao mesmo tempo, espaço social no senti do de produção de projetos de vida e de exercício de direitos, e de ampliação do poder de contratualidade social (BRASIL, 2015, p.23)
\end{abstract}

Os CAPS estão organizados em seis modalidades, sendo elas: CAPS I, CAPS II, CAPS III, CAPS AD, CAPS ADIII e CAPS i. Cada modalidade tem sua organização de acordo com o número de habitantes e nível de complexidade informado a seguir:

- CAPS I é indicado para municípios ou regiões de saúde com população acima de 15 mil habitantes e deverá ter uma equipe mínima composta por 1 médico com formação em saúde mental; 1 enfermeiro; 3 profissionais de nível universitário, 4 profissionais de nível médio; 
- CAPS II é indicado para municípios ou regiões de saúde com população acima de 70 mil habitantes e deverá ter uma equipe mínima composta por 1 médico psiquiatra; 1 enfermeiro com formação em saúde mental; 4 profissionais de nível superior, 6 profissionais de nível médio;

- CAPS III está em cidades com população acima de 150 mil habitantes e com atendimentos de maior complexidade, estando inclusos serviços de atenção contínua, com funcionamento 24 horas, incluindo feriados e finais de semana, internamentos devendo ter uma equipe mínima composta por 2 médicos psiquiatras; 1 enfermeiro com formação em saúde mental, 5 profissionais de nível universitário, 8 profissionais de nível médio;

- CAPS ad é indicado para municípios ou regiões de saúde com população acima de 70 mil habitantes devendo ter uma equipe mínima composta por 1 médico psiquiatra; 1 enfermeiro com formação em saúde mental; 1 médico clínico (responsável pela triagem, avaliação e acompanhamento das intercorrências clínicas), 4 profissionais de nível universitário e 6 profissionais de nível médio;

- CAPSad III oferece um serviço de observação e monitoramento com funcionamento 24 horas (feriados e finais de semana) com no máximo 12 leitos de hospitalidade. É indicado para municípios ou regiões com população acima de 150 mil habitantes e sua equipe composta por no mínimo 60 horas de profissional médico, entre psiquiatra e clínicos com formação e/ou experiência em saúde mental, sendo no mínimo 1 psiquiatra; 1 enfermeiro com experiência e/ou formação na área de saúde mental; 5 profissionais de nível universitário, 4 técnicos de Enfermagem; 4 profissionais de nível médio; 1 profissional de nível médio (atividades de natureza administrativa)

- CAPSi - Atende criança e adolescentes com sofrimento psíquicos (incluindo os casos por uso de substancias psicoativas), é indicado para municípios ou regiões com população acima de 70 mil habitantes e sua equipe deve ser composto por no mínimo 1 médico psiquiatra, ou neurologista ou pediatra com formação em saúde mental; 1 enfermeiro, 4 profissionais de nível superior, 5 profissionais de nível médio. (BRASIL, 2015). 
Todas as modalidades dos CAPS estão direcionadas para a atenção ao sujeito e seus familiares através de um trabalho multiprofissional local, tendo como foco o indivíduo.

Os Centros de Atenção Psicossocial (CAPS) deverão assumir seu papel estratégico na articulação e no tecimento dessas redes, tanto cumprindo suas funções na assistência direta e na regulação da rede de serviços de saúde, trabalhando em conjunto com as equipes de Saúde da Família e Agentes Comunitários de Saúde, quanto na promoção da vida comunitária e da autonomia dos usuários, articulando os recursos existentes em outras redes: sócio-sanitárias, jurídicas, cooperativas de trabalho, escolas, empresas, etc (BRASIL, 2004, p.12)

O CAPSi de Natal tem seu quadro de profissionais composto por: quatro Psiquiatras, cinco Psicólogas, um Terapeuta Ocupacional, uma Farmacêutica, uma Nutricionista (Administradora), duas Assistentes Sociais (sendo uma a diretora), uma Fonoaudióloga, um Oficineiro, dois Arte Educadores, duas Professoras de Educação Física, duas Enfermeiras, três técnicas em Enfermagem, dois Auxiliares de Serviços Gerais, uma Cozinheira, uma Auxiliar de cozinha, oito Vigilantes.

A instituição oferece consultas de Psiquiatria, Psicologia, Fonoaudiologia, Nutrição e Serviço Social. Oferta, também, oficinas terapêuticas em grupos, sendo elas: brinquedoteca, artes, música, jogos de mesa, oficina da fala, grupo de pais, psicomotricidade e natação; além de exames complementares, acolhimento, triagens; ofertam lanches e almoço aos assistidos, distribuição de medicamento. O CAPSi de Natal indicou um número de 898 indivíduos assistidos em março de 2015, sendo 115 indivíduos apontados com diagnostico dentro do Transtorno do Espectro Autista, população alvo deste estudo.

O projeto de extensão da UFRN denominado Psicomotricidade Relacional em parceria com o CAPSi, localizado na avenida Capitão Mor Gouveia - S/N na cidade de Natal, Rio Grande do Norte, oferta a oficina de Psicomotricidade Relacional para crianças assistidas pela instituição com diagnóstico de Transtorno do Espectro Autista, na qual é abordada a prática em grupo.

A oferta de uma atenção integral que estimule a autonomia do indivíduo, bem como do coletivo, é uma abordagem importante e está inserida nas práticas nos CAPS.

O processo grupal, desde que bem pensado em sua finalidade, estrutura e manejo, permite uma poderosa e rica troca de experiências e transformações subjetivas que não seria alcançável em um atendimento de tipo individualizado. Isto se deve exatamente à pluralidade de seus integrantes, à diversidade de trocas de conhecimentos e possíveis identificações que apenas um grupo torna possível (BRASIL, 2013, p. 121). 


\subsection{O TRANSTORNO DO ESPECTRO AUTISTA}

De acordo com a Organização das Nações Unidas, a prevalência de pessoas com o Transtorno do Espectro Autista na escala mundial está na proporção de 1 para 68 (ONU, 2016), sendo cerca de 1\% da população mundial acometida pelo Transtorno, com predominância do sexo masculino, o que é um achado epidemiológico consistente e que tem implicações etiológicas (LAI; LOMBARDO; BARON-COHEN, 2014).

À medida que se avança no conhecimento das patologias, em suas descrições e na facilidade em que circula as informações acerca dos direitos das pessoas, percebe-se uma mudança nos valores e comportamento social, o que permite a desconstrução de ideias preconceituosas. Pensando no autismo na atualidade, as discussões em torno de sua etiologia, prevalência e leis que asseguram os direitos de seus portadores, a Lei № 12.764, de 27 de dezembro de 2012 - Lei Berenice Piana (BRASIL, 2012), ganharam uma maior visibilidade, o que permite uma conscientização e reconhecimento de suas particularidades.

Faz-se necessário o conhecimento histórico para que se promova o entendimento acerca do diagnóstico do Transtorno do Espectro Autista, suas características, seu tratamento, terapia e o desenvolvimento do trabalho pedagógico.

\subsubsection{Histórico e Conceito do Transtorno do Espectro Autista}

O termo "Autismo" foi utilizado pela primeira vez na literatura médica em 1911 por Eugen Bleuler, para designar pessoas que tinham dificuldades de interagir com outras, trazendo como consequência o isolamento. A aplicação do termo utilizado por Bleuler era cunhado com o significado diferente do que se discute hoje, uma vez que ele estudava pessoas psicóticas e esquizofrênicas (STELZER, 2010).

O autismo infantil, suas características e as primeiras discussões foram descritos em 1943, pelo psiquiatra Leo Kanner. Este foi o responsável por observar que a criança autista tinha uma inabilidade ou incapacidade para estabelecer um relacionamento interpessoal e que possuía características comportamentais bastante específicas, tais como: perturbações na interação afetiva e social, maneirismo motor, estereotipias, isolamento extremo, falta de comunicação através da linguagem, 
ecolalia (eco da linguagem), preferência por rotinas, resistência à mudanças e predominância de incidência no sexo masculino (KANNER, 1943).

Em épocas bem próximas à publicação de Kanner, Hans Asperger publicou um artigo em alemão, no qual descreveu o comportamento de rapazes bastante semelhante ao grupo descrito por Kanner. Porém, ele identificou que eles possuíam um nível de Quociente Intelectual (QI) acima da média, uma habilidade maior no uso da fala e uma atividade motora desajeitada (ASPERGER,1943).

Ambos os trabalhos obtiveram impacto na literatura mundial em momentos diferentes (TAMANAHA; PERISSINOTO; CHIARI, 2008) e apesar de as publicações terem uma diferença de um ano e ambos os autores não terem acesso à publicação um do outro (SOARES, 2009), utilizaram o mesmo termo - autismo - uma vez que já havia sido introduzido por Bleuler, em 1911, para designar alguns comportamentos da esquizofrenia, o qual designava um distanciamento social e um mergulho em um mundo próprio por parte do paciente (STELZER, 2010).

Os dois autores supracitados descreveram comportamentos similares. No entanto, há diferenças nos campos das capacidades linguísticas e capacidades de aprendizagem. A falta de uma alteração significativa da linguagem e da cognição na síndrome de Asperger em diversos estudos salientava que a síndrome descrita por Asperger deveria ser considerada pertencente ao espectro do Autismo com uma possível base genética (TAMANAHA; PERISSINOTO; CHIARI, 2008).

Entre as décadas de 50 e 60 houve uma popularização da ideia que o autismo tinha sua causa nos pais, que davam tratamento de forma fria, com pouca afetividade para seus filhos, denominada hipótese das mães-geladeiras, disseminada pelo psicanalista austríaco Bruno Bettelhein, mas, na maior parte do mundo, essa noção foi abandonada na década de 70 (KLIN, 2006).

Bosa e Callias (2000) expõem algumas teorias psicanalíticas citadas no histórico etiológico do Autismo e discorrem sobre as ideias de Margaret Mahler, apontando o autismo como uma fase do desenvolvimento psicológico do bebê, no qual na primeira fase (duas primeiras semanas de vida) há uma falta de consciência do papel da mãe por parte do bebê, seguido da fase em que há uma consciência de que suas necessidades são sanadas a partir de um lugar externo ao eu. No segundo mês de vida há uma simbiose e o bebê percebe que há uma unidade dual e, somente por volta dos 6 meses, há uma separação, levando o indivíduo à sua organização. $A$ 
ideia de Margaret Mahler sobre o autismo é proveniente de sua teoria evolutiva e é apresentada como um subgrupo das psicoses infantis, estando regressiva a uma fase de não diferenciação perceptiva, em que há predomínio na dificuldade de integração das sensações do mundo externo e interno e a não percepção da mãe como agente externo.

Tustin, em 1981, reconhecia o autismo também como sendo uma fase normal no desenvolvimento infantil, mas diferenciando-se do autismo patológico por uma questão de grau de comprometimento, e que este decorria de uma reação a uma separação traumática materna, a qual levava a criança a obter sensações de forma desorganizada, atingindo um colapso depressivo (BOSA; CALLIAS, 2000). Nesta perspectiva, o autismo pode ser uma estrutura de personalidade ou mesmo uma psicopatologia, caso o comportamento seja inadequado e/ou exagerado.

Lorna Wing, em 1976, propôs a conceituação do "espectro do autismo", visando demonstrar a variedade das manifestações do comportamento de um mesmo distúrbio (SOARES, 2009). Ao autismo direcionaram-se características e déficits específicos para a linguagem e comunicação, para as competências sociais e para a capacidade da imaginação. Estas três áreas apontadas como deficitárias frequentemente associadas às disfunções da fala, deficiências motoras e sensoriais, mais conhecidas por Tríade de Wing, tornaram-se a base para o diagnóstico do Transtorno do Espectro Autista (SOARES, 2009; FERREIRA, 2011).

As definições para o autismo são várias e mostram que este pode ser proveniente tanto de causas genéticas como de uma síndrome durante 0 desenvolvimento, o que acaba por sugerir que ainda há um enigma a ser revelado, que impele dificuldade no diagnóstico precoce (CUNHA, 2010). Essa diversidade sobre uma possível explicação etiológica do autismo dá-se quando teóricos de correntes cognitivistas e psicanalistas interessados pelo autismo apresentam várias teorias explicativas diferentes: Baron-Cohen apresenta a "teoria da mente", que acredita que o indivíduo com Transtorno do Espectro Autista apresenta dificuldades de interpretar ou imaginar estados mentais de terceiros, bem como de si próprio (“metarrepresentação" e "metacognição") (BOSA; CALLIAS, 2000).

Falkenbach, Diesel e Oliveira (2010) apresentam uma conceituação do autismo sob uma ótica pedagógica acerca das aprendizagens, mas que converge na caracterização, definindo-o como um transtorno do desenvolvimento e síndrome 
comportamental de causas múltiplas, que traz consigo prejuízos na interação social, na linguagem e alterações comportamentais.

São descritos na décima revisão da Classificação Internacional de Doenças CID 10 - (OMS, 2008), os Transtornos Globais do Desenvolvimento e as características globais do funcionamento do indivíduo pertencentes a esse grupo, o qual se caracteriza por alterações qualitativas na interação social e na comunicação, com interesses restritos e atividade estereotipada. A CID 10 ainda distingue o Autismo Infantil como uma alteração que se manifesta antes dos três anos de idade cronológica, que apresenta perturbação do funcionamento nas áreas da interação social, comunicação e comportamento repetitivo, e o quadro de síndrome de Asperger, que apresenta uma validade incerta para a ciência que trata das classificações das doenças (nosologia) e é caracterizada por perturbação qualitativa nas áreas da interação social e de interesses restritos (OMS, 2008).

A quinta edição do Manual Estatístico e Diagnóstico de Transtornos Mentais DSM, publicada em maio de 2013 - Versão em inglês - (APA, 2014), adotou o termo guarda-chuva Transtorno do Espectro Autista - TEA sem uma definição de subtipos. Ou seja, o transtorno autista, o transtorno degenerativo da infância, o transtorno de Asperger e o transtorno invasivo do desenvolvimento sem outra especificação passaram a ser considerado Transtorno do Espectro Autista. O DSM-5 reorganizou a tríade - deficiências na interação social; deficiências na comunicação; comportamentos repetitivos, estereotipados e interesses restritos - em uma díade, descrevendo-a como uma dificuldade na interação e comunicação social; comportamentos repetitivos e atividades e interesses restritos.

\subsubsection{Intervenções no Transtorno do Espectro Autista}

Em função de suas características, o Transtorno do Espectro Autista exige um acompanhamento perpétuo, necessitando de uma intervenção a qual dê respostas para esses déficits. As intervenções devem estimular as áreas da cognição, da socialização, da comunicação, da autonomia, do comportamento, do jogo e das competências educacionais (LIMA, 2012). Na tentativa de minimizar as características peculiares do autismo, existem diversas intervenções que são utilizadas com o Transtorno do Espectro Autista, dentre elas, as psicomotoras, as psicoeducativas, a farmacológica e as terapias complementares. 
A intervenção psicomotora tem como base a Psicomotricidade que é considerada uma ciência transdisciplinar que investiga as relações e as influências do psiquismo e do corpo reciprocamente (FONSECA, 2010). Ela objetiva o estudo das relações do homem e do mundo interno (sensações, sentimentos, pensamentos) e do mundo externo (objetos, outras pessoas) através do seu corpo em movimento (DORNELES; BENETTI, 2012).

Lapierre, autor central da intervenção deste estudo, ressalta a Psicomotricidade Relacional não somente sobre um enfoque de compensar o déficit da criança com Transtorno do Espectro Autista, mas atingir as origens dos sintomas de forma mais profunda, a raiz psicoemocional, as desordens relacionais, as demandas afetivas inconscientes; ele ainda ressalta que há basicamente dois tipos de intervenção psicomotora: a de cunho psicanalítico e a de cunho comportamental. Ele conceitua que o jogo simbólico vivido na sessão da Psicomotricidade Relacional é uma terapia, por ser por si só uma regressão que apresenta um efeito terapêutico, uma vez que o jogo é essencialmente não verbal, sem julgamentos, e que possibilita que as expressões corporais simbólicas, o imaginário e a fantasia se manifestem livremente, fora dos limites da realidade. No jogo não verbal, o corpo é a única fonte de expressão e comunicação, o que modela o funcionamento psíquico e a forma de pensar, sendo uma forma análoga aos sonhos, o que Freud chama de regressão formal (LAPIERRE, 2008).

As intervenções psicoeducativas baseiam-se em ensinar às crianças, através de técnicas especializadas e estruturadas, novas habilidades e comportamentos (MULAS, 2010). Os métodos mais conhecidos e referenciados são: o modelo TEACCH (Treatment and Education of Autistic and related Communication handicapped Children / Tratamento e Educação de Autistas e Crianças com limitações "Handicapped" relacionadas à Comunicação); o programa ABA - Applied Behavior Analysis / Análise Aplicada do Comportamento; o DIR (Developmental, Individualdifferences, \& Relationship-based model / Desenvolvimento Diferencial Individual e Relacional/); o PECS (Picture Exchange Communication System / Sistema de Comunicação por Troca de Figuras; o SIT (Sensory Integration Therapy, para o desenvolvimento de competências sensório-motoras); e o programa PBS (FamilyCentred Positive Behaviour Support Programs) no qual se utiliza a inclusão da família 
na intervenção (MULAS, 2010). Essas técnicas são diretivas e tem uma estruturação padrão de aplicabilidade.

A intervenção farmacológica vem sendo apontada como uma ação complementar para redução dos sintomas que provocam problemas no autismo (NIMH, 2011). Este tipo de intervenção tem tido um progresso para indivíduos com o Transtorno do Espectro Autista (DOYLE; MCDOUGLE, 2012).

Algumas terapias complementares têm sido apontadas na literatura e utilizadas com os indivíduos com Transtorno do Espectro Autista, dentre elas a acupuntura, a terapia assistida por animais (LOFTHOUSE et al., 2012), a dieta sem glúten, antifúngicos e secretina (LIMA, 2012), massagens, musicoterapia, reiki e ioga (LIMA, 2012; LOFTHOUSE et al., 2012).

\subsection{A PSICOMOTRICIDADE RELACIONAL}

A Psicomotricidade Relacional é uma prática pedagógica, dedicada à atividade espontânea e ao brincar que utiliza o imaginário e o simbólico, o emocional e o afetivo, dispondo à criança e ao adulto diferentes objetos nos quais observa-se a interação entre eles (LAPIERRE; AUCOUTURIER, 2004).

A Psicomotricidade Relacional coloca o indivíduo em uma situação de busca, a partir de seu próprio corpo, do objeto, do espaço em que se encontra e do outro (LAPIERRE; AUCOUTURIER, 2004). Dispõe-se a engajar-se nas vias das pulsões (vontades; o que impulsiona), dos desejos primitivos do inconsciente, encontrando no corpo a significância afetiva para o seu movimento, propondo um espaço para que o indivíduo vivencie o seu potencial e criatividade de forma espontânea e livre (LAPIERRE; AUCOUTURIER, 2004).

\footnotetext{
É essa vivência simbólica, arraigada no inconsciente, que, hoje, nos parece, fundamental. Em nossa opinião, é possível atingir, por meio dessas situações, as camadas mais profundas da personalidade, abordando esse núcleo psicoafetivo que, em última análise, determina todo o porvir do ser (LAPIERRE; AUCOUTURIER, 2004 p.12).
}

É importante que se estabeleça uma comunicação psicomotora com as crianças menores, necessitando uma aproximação corporal e motora para estabelecer a comunicação (LAPIERRE; LAPIERRE, 2002). 
(...) Uma relação na qual o adulto parecia abandonar seu papel "educativo", seu papel "pedagógico", para se entregar a todos os caprichos das crianças. "Uma relação em que o adulto não impunha nenhuma ordem, nenhuma estrutura, parecendo, por isso, um "laxismo", um "abandono" corporal que permitiam relações cuja intimidade nos chocava" (LAPIERRE; LAPIERRE, 2002, p. 22).

O papel do educador, na Psicomotricidade Relacional, é atender as necessidades da criança e isso engloba a necessidade afetiva, pois a criança na ausência dos pais sofre. Deve haver uma substituição simbólica e provisória, materna e paterna, em que haja a possibilidade de a criança dar continuidade à sua vida afetiva (LAPIERRE; LAPIERRE, 2002).

O jogo da criança é naturalmente um jogo espontâneo, por ser imaginário e onipotente; desse modo funciona através do pensamento analógico, o mesmo do inconsciente (LAPIERRE, 2008). Os objetos se convertem em suas fantasias inicialmente através de analogias conscientes e com o decorrer do jogo acabam por ganhar significados de modo inconsciente. Por exemplo, quando uma caixa é apresentada a uma criança, inicialmente ela associa a sua casa, inclusive verbalizando; em seguida, acessa o inconsciente, podendo manifestar expressões corporais que indicam uma regressão ao útero da mãe; ao aproveitar o prazer fusional, a criança sai da caixa e geralmente a destrói, o que simboliza a sua vontade de libertar-se da dependência e separar-se da figura materna (LAPIERRE, 2008).

A regressão é uma terapia, visto que compõe uma conexão entre o consciente e o inconsciente (LAPIERRE, 2008).

[...] É apenas a partir desta regressão, deste revivenciamento das relações corporais primárias que será possível reestruturar as etapas posteriores que dela decorrem: espaço fusional, comunicação simbólica e afirmação da identidade. (LAPIERRE; AUCOUTURIER, 1984, p. 57).

O jogo é uma sobreposição da realidade e do imaginário em que as duas partes da personalidade, geralmente separadas, se reencontram (LAPIERRE, 2008). A verbalização após as sessões permite a compreensão da expressão do consciente; o jogo pode levar o indivíduo a etapas mais primárias e, através da análise, reestruturar sua personalidade (LAPIERRE, 2008). A brincadeira é a principal atividade da criança, sua linguagem própria e natural e um meio de interação e de expressão acerca do que sente e pensa, através das relações com os pares e com o mundo que a cerca (SOUZA, 2011). 
O brincar possibilita à criança liberar seus medos, permitindo-a sentir-se potente para dominá-los.

Existe na criança, quem quer que ela seja, múltiplas potencialidades positivas que são possíveis descobrir e desenvolver desde que não se esteja fixado pelo que ela não sabe fazer. Centralizar sua atenção num sintoma é fixá-lo, estruturá-lo. Esquecê-lo é talvez permitir que desapareça já que não apresenta mais interesse (LAPIERRE; AUCOUTURIER, 1988, p.13).

A brincadeira acontece no campo do imaginário e do simbólico, o que consente que a criança traga coisas da realidade para ressignificá-las em um outro espaço (VYGOTSKY, 2007).

Se levarmos em conta um dos marcos teóricos da Psicomotricidade relacional
que é a comunicação não verbal manifestada através do jogo espontâneo,
onde o corpo participa com todas as suas dimensões representativas
inseridas em uma complexa rede de inter-relações, onde estão presentes
conteúdos biológicos, psicológicos, somáticos, vivenciais, históricos e
sociais, podemos então compreender e não apenas interpretar, os conflitos
intrapsíquicos e suas repercussões psicossomáticas, possibilitando ao ser
humano a capacidade para redimensionar suas relações, de forma que possa
obter melhores condições de vida e bem estar pessoal, familiar, físico, social
e profissional (VIEIRA; BATISTA; LAPIERRE, 2005, p. 42).

A criança quando vivencia um programa em Psicomotricidade Relacional, mostra-se com maior domínio motor, desenvolvimento cognitivo, emocional, social e com maior autonomia e qualidade nas relações em sua vida diária. (GLASENAPP, 2012). O trabalho pontuado no que a criança sabe fazer e não no que ela não sabe pode fluir para uma situação em que a criança obtém confiança e segurança, passando a constituir não mais uma reeducação e sim uma educação, em que há o desenvolvimento de suas potencialidades (LAPIERRE; AUCOUTURIER, 2004).

Nós queremos trabalhar com aquilo que há de positivo na criança; nós nos interessamos por aquilo que ela sabe fazer, e não pelo que ela não sabe fazer. [...] O melhor modo de ajudar a vencer as dificuldades é fazer com que elas sejam esquecidas (LAPIERRE; AUCOUTURIER; 2004, p. 19 - 20)

Utilizando-se de objetos diversos e de diferentes texturas, há uma utilização do corpo em sua totalidade e com todas as possibilidades de investimento simbólico, nas quais todas as probabilidades de movimentação corporal e atividade motora dinâmica são exploradas: as pessoas pulam para dentro dos arcos, saltam por cima das cordas, caminham sobre os bancos e deslocam-se por entre os objetos (LAPIERRE; AUCOUTURIER, 2004). 
$\mathrm{Na}$ Psicomotricidade Relacional podemos destacar a riqueza de movimentação corporal, na qual a criança tem a oportunidade de vivenciar diversos gestos motores:

Essa vivência do corpo no chão não tem nada de racional nem de analítico.
É busca de prazer e, primeiramente, prazer do deslocamento; arrastar-se em
decúbito dorsal, de lado, a busca do apoio das mãos, dos cotovelos, dos
joelhos, permitindo uma progressão mais rápida; deslizar sobre as diferentes
partes do corpo, rolar, andar de quatro, deslocar-se por impulso (LAPIERRE;
AUCOUTURIER, 2004).

"A atividade motora espontânea é uma porta livre expressão do imaginário e do simbólico, ao desenvolvimento da comunicação" (FRANCO, 2000).

Os materiais utilizados nas sessões de Psicomotricidade Relacional assumem significados simbólicos, os quais podem modificar-se ao passo que cada indivíduo vivência uma história (LAPIERRE, 2002)

Lapierre e Aucouturier (2002) explicam que a Psicomotricidade Relacional segue uma rotina estruturante, na qual eles chamam de ritual de entrada, sessão e ritual de saída. Os objetos utilizados na intervenção são materiais clássicos (bolas, bastões, tecidos, caixa, entre outros) e carregam em si um valor simbólico, o qual cria um ponto de contato com as crianças autistas, favorecendo as relações de afeto.

Através dos jogos simbólicos, o indivíduo expressa seus sentimentos, emoções, construindo as representações mentais, assimilando a realidade percebida, adaptando-se fisicamente e psicologicamente (PIAGET, 1975). O jogo é importante para o desenvolvimento da ação criativa, uma vez que existe uma relação entre jogo e aprendizagem (VYGOTSKY, 2007).

As sessões de Psicomotricidade Relacional apresentam as fases do desenvolvimento no jogo simbólico, descritos abaixo:

Inibição: Caracterizado como um momento em que a criança não se apresenta disponível para sua participação ou se comporta de forma passiva diante da relação.

Agressividade: a agressividade é um fator do domínio afetivo humano, integrante da pulsão de vida; é uma fase importante que a criança passa e que aparece durante as atividades de forma evidente, na qual ela exprime o desejo de destruição; quando direcionada ao adulto, a criança deseja destruir o símbolo do poder e da autoridade (FRANCO, 2000)

Domesticação: A agressividade é pulsão de vida, ou seja, este comportamento trata-se de um meio para atingir os objetivos e não um fim. A criança destrói o 
professor simbolicamente, tomando o poder do adulto e afirmando seu papel, num processo de inversão de papéis.

Fusionalidade: É uma experiência corporal regressiva com grande carga afetiva. É a busca do acordo tônico (LAPIERRE, 2002).

Autonomia: a autonomia é a última fase a ser atingida no jogo simbólico, passando por todas as fases descritas acima. Porém ela não é de caráter linear, ou seja, a criança pode pular as etapas e apresentar-se autônoma; A autonomia é construída internamente e resulta da resposta da pessoa ao seu meio, quando estão satisfeitas suas necessidades de afeto, limite e frustração (LAPIERRE; AUCOUTURIER, 2004).

A Psicomotricidade Relacional acredita que um mudo melhor é composto pela contribuição de indivíduos autônomos e a evolução das brincadeiras e do jogo simbólico facilita à criança progredir na construção de sua identidade pessoal e social, as quais são requisito básico para uma autonomia duradoura e autoconsciente (FRANCO, 2000).

\subsection{HABILIDADES MOTORAS E SEU DESENVOLVIMENTO}

O desenvolvimento motor caracteriza-se por estágios/fases com características peculiares, nas quais cada um possui sua natureza evolutiva desde a fase de reflexos até a fase de movimentos especializados (COELHO, 2010). Sendo assim, o desenvolvimento motor é um processo evolutivo de mudanças que ocorrem em sequência e é o resultado das interações entre a maturação e a aprendizagem ao longo da vida, regulado pela influência mútua da tarefa, do indivíduo e do ambiente (GALLAHUE; OZMUN; GOODWAY, 2013).

O desenvolvimento motor na infância caracteriza-se pela sua ampla disponibilidade de habilidades motoras, que possibilitam à criança um vasto domínio corporal em diferentes posições, permitindo a locomoção por diversos ambientes de variadas formas (andando, correndo, saltando, etc.) com manipulação de objetos (receber, arremessar, chutar, escrever, etc.), solicitados na rotina diária das brincadeiras e em diversos ambientes, requerendo da criança, o domínio de várias habilidades (SANTOS; DANTAS; OLIVEIRA, 2004). Considerada como um padrão do movimento fundamental e realizada de forma precisa, exata e controlada 
(GALLAHUE; OZMUN; GOODWAY, 2013), as habilidades motoras representam ferramentas que o indivíduo possui e determina a proficiência da execução da tarefa motora a qual está submetida, no qual o movimento é uma janela para o processo do desenvolvimento motor (LOPES et al, 2011).

O desenvolvimento das crianças é imaturo, por isso, é necessário estimular experiências motoras significativamente apropriadas para seu nível de desenvolvimento particular (GALLAHUE; OZMUN; GOODWAY, 2013). Além disso, as habilidades básicas são importantes, pois dão suporte para as aquisições futuras das crianças e suas aprendizagens, permitindo uma sequência de movimentos que nos leva a saber que a fase de habilidades básicas e a fase de habilidades específicas interdependem uma da outra, reforçando a importância das aquisições motoras iniciais da criança na primeira e segunda infâncias e o sucesso das habilidades que serão adquiridas posteriormente (SANTOS; DANTAS; OLIVEIRA, 2004).

A atividade motora é essencial para que as crianças se desenvolvam de forma global (ROSA NETO, 2014). Portanto, o ambiente e as condições de vida em que a criança está inserida condicionam suas experiências motoras, o que implica dizer que estas influenciam diretamente no desenvolvimento e nos padrões de movimentos que se aprimoram durante as idades pré-escolares, as quais são as bases para várias possibilidades de prática de atividade física (LOPES, 2011).

O movimento corporal é de fundamental importância para a vida humana e as aprendizagens das habilidades motoras e os padrões de movimento iniciam-se na infância, a partir dos mais simples gestos corporais até as formas mais complexas (GALLAHUE; OZMUN; GOODWAY, 2013). Os aprimoramentos das habilidades motoras da criança devem ser derivados de momentos de experimentação e erros para que o desenvolvimento motor aconteça (TORQUATO, 2013).

As habilidades motoras da criança se desenvolvem em função de uma dependência de um mundo exterior e suas exigências, que são percebidas através de seu corpo à medida que há uma interação entre estes (ROSA NETO, 2014). Habilidade motora é a ação aprendida ou orientada de movimentar o corpo e/ou partes dele de forma voluntária para se alcançar determinado objetivo, não englobando movimentos reflexos ou movimentos de base genética (rastejar, engatinhar do bebê) (GALLAHUE; OZMUN; GOODWAY, 2013). 
Tem-se o conceito do movimento como sendo as mudanças que podemos observar na posição de qualquer parte do corpo, sendo uma parte que compõe as habilidades, associada a derivação dos processos motores subjacentes (MAGILL, 2000; GALLAHUE; OZMUN; GOODWAY, 2013).

Quanto as habilidades dos movimentos, elas podem classificar-se em função de uma série de esquemas, sendo os dois mais citados na literatura: unidimensionais (classificação do movimento: muscular, temporal, ambiental e funcional) e bidimensionais (conforme a intenção, subdividindo-se em: tarefas de estabilidade, tarefas de locomoção e tarefas de manipulação de objetos. (MAGILL, 2000; GALLAHUE; OZMUN; GOODWAY, 2013).

Gallahue, Ozmun e GODWAY (2010) dividem e classificam as habilidades motoras fundamentais em:

a) Habilidade motora de estabilidade: qualquer movimento que exija um controle muscular quando exposto à gravidade;

b) Habilidade motora de locomoção: movimentos que provocam uma mudança na localização do corpo em relação a um ponto fixo, através das habilidades básicas;

c) Habilidade motora de manipulação: contato com objetos através das habilidades rudimentares de alcançar, segurar e soltar.

De acordo com Rosa Neto (2014), dentro do campo do movimento, a avaliação do desenvolvimento motor, das habilidades motoras e de suas áreas permitem a compreensão dos movimentos executados pela criança e o acompanhamento durante determinado período, podendo ser identificados precocemente alterações do desenvolvimento motor infantil (ROSA NETO, 2014).

O autor supracitado elenca na Escala de Desenvolvimento Motor, áreas avaliativas das habilidades motoras, resultando nas aptidões motoras referente a cada uma delas. São elas:

\subsubsection{Motricidade Fina:}

A motricidade fina caracteriza-se pelos movimentos apendiculares espontâneos que envolvem a exploração de objetos com as mãos e as atividades manipulativas em determinadas tarefas (ALMEIDA; VALENTINI, 2013). A coordenação viso-motora é a ação conjunta que ocorre quando há um processo de 
interação entre o ato motor e uma estimulação visual de forma coincidente (ROSA NETO, 2014).

\subsubsection{Motricidade Global}

A motricidade global caracteriza-se pelos movimentos axiais espontâneos, os quais englobam tarefas de deslocamento e postura (ALMEIDA; VALENTINI, 2013).

O movimentar da criança de forma espontânea na produção das ações corporais, dos gestos, deslocamentos e o movimento motor dinâmico corporal influenciam na melhora dos comandos nervosos e no refinamento das percepções e da qualidade do movimento executado (ROSA NETO, 2014).

\subsubsection{Equilíbrio}

É a base de toda ação dos segmentos corporais, através da qual o sistema nervoso central recebe informações dos sistemas sensoriais e envia comandos ao sistema muscular. O equilíbrio é obtido através da integração das informações do sistema vestibular, somatossensorial e visual. Considera-se que um corpo está em equilíbrio quando as forças que atuam sobre ele se compensam e se anulam de forma mútua (DUARTE; ZATSIORSKY, 2000; ROSA NETO, 2014).

\subsubsection{Esquema Corporal}

A imagem do corpo se organiza mediante o meio como núcleo central da personalidade. Ela é o código de toda organização do sujeito, que acompanha a maturação do sistema nervoso e do desenvolvimento infantil. Sua organização e identificação partem do sentido céfalo-caudal e próximo-distal (ROSA NETO, 2014). Através desta habilidade motora, a criança pode estabelecer uma relação do seu corpo com as informações do mundo externo, possibilitando ser ela mesma um ponto inicial para várias possibilidades de ações (BOULCHE, 1987).

\subsubsection{Organização Espacial}

A organização espacial depende da percepção do nosso corpo, do ambiente e de suas características com participação dos sistemas sensoriais, os quais nos 
orientam na avaliação do preenchimento físico do corpo mediante o espaço, ajudando-nos nas trajetórias e nos desvios (ROSA NETO, 2014). Esta habilidade é possibilitada através da construção mental do sujeito e seus movimentos em relação aos objetos em sua volta no ambiente que está inserido (OLIVEIRA, 2009).

\subsubsection{Organização Temporal}

A percepção do tempo se dá mediante os acontecimentos e as mudanças do que é passado, presente e futuro. A organização temporal inclui uma dimensão lógica, uma dimensão convencional e uma dimensão de vivências, nas quais a consciência do tempo se constrói sobre as transformações que percebemos (ROSA NETO, 2014).

\subsubsection{Lateralidade}

Nosso corpo constitui-se em partes anatômicas e simétricas com uma assimetria funcional em que algumas atividades somente são executadas a partir de um dos lados. A lateralidade é entendida como a preferência de um dos lados do corpo para executar determinada tarefa (ROSA NETO, 2014).

A aquisição de repertório motor, permite ao indivíduo uma autonomia no movimentar-se para a realização das habilidades motoras fundamentais e é a base para as habilidades especializadas (RIBEIRO; BONONE, 2014). As habilidades motoras fundamentais fazem parte de uma fase do desenvolvimento motor da criança e que se faz presente nas atividades da vida diária das pessoas, seja no banho, ao se alimentar, ou praticando uma atividade física (RIBEIRO; BONONE, 2014).

\subsection{CONTROLE POSTURAL}

O controle motor é a capacidade de regular os mecanismos necessários para a movimentação corporal e seu campo estuda a natureza do movimento e como este é controlado. Visto que o movimento é resultante da interação entre o indivíduo, o ambiente e a tarefa, esse passa a ser específico da tarefa e limitado pelo ambiente (SHUMWAY-COOK; WOOLLACOTT, 2010).

A capacidade funcional de uma pessoa é determinada pela habilidade que ela possui em cumprir as demandas exigidas pela tarefa, através da interação com o ambiente, apesar de que, em um indivíduo, o movimento emerge através do 
sincronismo entre várias estruturas e processos cerebrais incluindo os associados à percepção, à cognição e à ação. (SHUMWAY-COOK; WOOLLACOTT, 2010).

Nas atividades motoras, deve-se ter uma coordenação entre a postura e o movimento com o intuito de que se alcance o objetivo da tarefa (SILVA, 2016). Quando a criança adquire um bom controle motor, constrói noções básicas também para seu desenvolvimento cognitivo (ROSA NETO et al, 2010). Pesquisas sugerem que existe uma relação entre disfunção cognitiva e sintomas de instabilidade postural e alterações na marcha (KELLY et al, 2015)

A postura é apontada pela posição dos segmentos corporais, mediante sua amplitude e o controle postural é o resultado de uma interação complexa entre os sistemas neural e musculoesquelético (SHUMWAY-COOK; WOOLLACOTT, 2010) sendo um alicerce fundamental para que as atividades diárias do indivíduo sejam desempenhadas de forma eficiente (MEMARI, 2013).

O equilíbrio corporal é de responsabilidade do controle postural, uma vez que este é um conceito atribuído para as funções desempenhadas pelo sistema nervoso, sensorial e motor (SOUSA, 2012). A manutenção do equilíbrio é uma tarefa complexa que requer uma maturação do sistema de controle postural, o qual é consequência de um processo intencional do sistema nervoso central em que há uma busca pelo limite da estabilidade corporal (KEGEL et al, 2010).

Nesse contexto, o equilíbrio é uma habilidade fundamental para o desenvolvimento motor de crianças. Assim, o controle postural é um pré-requisito básico para o movimento e base para o desenvolvimento motor e desempenho das atividades da vida diária (WESTCOTT; LOWES; RICHARDSON, 1997; KEGEL ET AL, 2010; D'HONDT ET AL, 2011).

O equilíbrio pode ser dinâmico (habilidade de manter-se em equilíbrio durante mudanças de posições sucessivas) ou estático (habilidade de manter-se em equilíbrio numa determinada posição) (DUARTE; ZATSIORSKY, 2000). Dizemos que um corpo está em equilíbrio quando a somatória das forças que atuam sobre ele é igual a zero, o que para o corpo humano não é uma tarefa fácil (ENOKA, 2000), uma vez que a postura ereta é um momento em que o corpo não está totalmente parado, pois produz pequenas oscilações posturais (DUARTE; FREITAS 2010). Existe uma associação entre um maior esforço para a manutenção do equilíbrio e oscilações posturais aumentadas (HASAN et al, 1997). 
O controle postural é definido como a ação de manter ou restaurar o equilíbrio em qualquer postura ou atividade (POLLOCK et al, 2000), sendo atribuído a ele, a capacidade de controlar a posição do corpo no espaço para conseguir a orientação e estabilidade (DUARTE e FREITAS, 2010; SHUMWAY-COOK E WOOLLACOTT, 2010). Cada postura requer uma resposta neuromuscular necessária para que o corpo se mantenha equilibrado (DUARTE; FREITAS, 2010).

A estratégia da postura bípede humana é instável em função da base de suporte ser pequena e o centro de gravidade ser alto (nível do quadril), na qual encontra-se o ponto de equilíbrio de toda a massa corporal e o ponto resultante das forças externas que agem sobre o corpo (TEIXEIRA, 2010). Uma vez que para que haja controle do equilíbrio, biomecanicamente, é preciso que o centro de gravidade se mantenha sobre a base de sustentação (GRIBBLE; HERTEL, 2004; BRUNIERA, 2015).

Manter-se em equilíbrio na postura ereta é, para o corpo humano, uma tarefa importante e complexa, uma vez que o equilíbrio é garantido através da integração das informações através de feedback pelos sistemas visual, vestibular e sensorial que captam informações, enviam ao sistema nervoso central, o qual processa essas informações, integra, planeja e comanda respostas motoras de ajustes posturais através do sistema muscular (DUARTE; ZATSIORSKY, 2000; BRUNIERA et al, 2015) Estas informações influenciam modificações no padrão de movimento (SILVA, 2016).

Para cada sistema é direcionada uma função. O sistema sensorial é responsável por fornecer informações a respeito da posição dos segmentos corporais diante dos demais segmentos e do ambiente; ao sistema visual é atribuída a responsabilidade de fornecer informação da direção e velocidade dos segmentos corporais em relação ao ambiente fazendo distinção entre a movimentação corporal e objetos externos (NASHNER, 1981), o que possibilita ao indivíduo detectar profundidade, texturas e sombras e facilita sua orientação postural no espaço (DASCAL, 2009); o Sistema Nervoso Central (SNC) integra informações do sistema sensorial e comanda, através dos impulsos elétricos, o sistema motor que gera respostas neuromusculares que ativam a musculatura correspondente para a realização dos movimentos, tornando-se responsável pelo movimento e pela manutenção da postura; (SHUMWAY-COOK; WOOLLACOTT, 2010). 
O controle postural é um atributo fundamental da habilidade motora, pois permite ao indivíduo manter a posição do corpo da forma desejada (TRAVERS, 2013) com o propósito de proporcionar orientação e estabilidade, uma vez que a orientação se define como a habilidade relacionada entre os segmentos do corpo, o ambiente e/ou a tarefa exigida; e a estabilidade é a habilidade de manter o corpo em equilíbrio, o que é um processo dinâmico que envolve o equilíbrio entre forças que estabilizam e desestabilizam (SHUMWAY-COOK; WOOLLACOTT, 2010).

Atividades motoras específicas demandam um controle postural maior e, por isso, recorrem a uma variável do equilíbrio postural, o Centro de Pressão (COP), que depende do feedback sensorial e sua análise tem sido utilizada em avaliações para reabilitação do equilíbrio postural (DANION et al., 1999).

O meio mais comum de medir o controle postural é com a posição do corpo ereto, estático, modo em que se registra dados da oscilação do Centro de Pressão (COP) provenientes da plataforma de força (FREITAS et al, 2009), sendo esta ferramenta a mais comumente utilizada para estudos posturais (FREITAS et al, 2009; LOTH et al, 2011; MEMARI et al, 2013). 


\section{METODOLOGIA}

\subsection{DELINEAMENTO DO ESTUDO}

A pesquisa é do tipo exploratória-descritiva, cujo valor está baseado na premissa de que a observação, a análise e a descrição viabilizam a resolução de problemas. A metodologia desenvolvida com delineamento de um estudo de caso único avaliativo, de cunho qualitativo, distingue-se por se tratar de um participante que no momento inicial tinha o diagnóstico do Transtorno do Espectro Autista, o que permite uma compreensão profunda sobre a situação ou tema de estudo (RUDIO, 2003). O estudo de caso avaliativo abrange tanto a descrição quanto a interpretação, mas o objetivo principal é usar os dados para avaliar o mérito de alguma prática, programa, movimento ou evento.

Os autores traduzem como uma investigação, no sentido de uma compreensão profunda e, por conseguinte, possibilitando uma contribuição no campo de pesquisas para a análise e explicação de casos similares, corroborando com as bases empíricas e analíticas na área de Educação Física, pois versa sobre a melhoria da qualidade de vida dos indivíduos.

Quando se trata de estudo de caso na linguagem da avaliação, as explicações servem para unir a aplicação do programa com os efeitos causados por ele (YIN, 2003).

A pesquisa foi realizada no CAPS-i, por tratar-se de uma instituição com características peculiares que trabalha com indivíduos com algum tipo de comprometimento intelectual, patologias mentais e indivíduos autistas, foco da pesquisa. Além disso, mais especificamente, pela busca de circunstâncias que podem confirmar ou ampliar a abordagem da Psicomotricidade Relacional, conforme as ideias de Yin, quando afirma:

Uma justificativa para o caso único é quando ele representa o caso crítico no teste de uma teoria bem formulada (observe novamente a analogia com 0 experimento decisivo). A teoria especificou um conjunto claro de proposições, assim como as circunstancias em que elas são consideradas verdadeiras. $O$ caso único, preenchendo todas as condições para o teste da teoria, pode confirmar desafiar ou ampliar a teoria. Ele pode ser usado, então, para determinar se as proposições da teoria são corretas ou se algum conjunto alternativo de explanações pode ser mais relevante. (YIN, 2010, p. 71). 
Por conseguinte, uma pesquisa qualitativa de cunho descritivo pode oportunizar ao pesquisador o alcance analítico para que possa indagar a problemática estudada e confrontá-la com outras situações já conhecidas e com teorias existentes. Para que isso possa ocorrer no estudo de caso, o pesquisador pode se valer de uma grande variedade de instrumentos e estratégias e confrontar as situações com outras já conhecidas e com as teorias existentes, no sentido de gerar novas questões para futuras investigações.

Para Yin, o estudo de caso se aplica quando se busca explicar os vínculos causais em intervenções da vida real que são complexas demais para estratégias experimentais. Outra aplicação é descrever uma intervenção e o contexto na vida real em que ela ocorre, seja para fazer uma avaliação, mesmo que descritiva, da intervenção realizada, ou ainda para explorar aquelas situações nas quais a intervenção que está sendo avaliada não apresenta um conjunto simples e claro de resultados (YIN, 2010).

\subsection{LIMITAÇÕES DO ESTUDO DE CASO}

O estudo de caso é criticado por limitar-se nos seguintes aspectos: falta do rigor cientifico e fornecimento de pouca base para generalização científica. Contudo, em resposta às críticas, Yin (2010) se posiciona da seguinte maneira: nos procedimentos experimentais, questionários ou na condução de pesquisas históricas, a falta de rigor na pesquisa é detectada quando se pretende os resultados para os objetivos desejados. De modo a evitar que isso aconteça, o pesquisador deve trabalhar com obstinação no sentido de expor os dados de forma justa, utilizando-se de instrumentos validados e confiáveis para coleta de dados.

Quanto à generalização, o estudo de caso, como experimento, não representa uma amostragem, o objetivo deste método, portanto, é generalizar, não estatisticamente, mas de maneira analítica uma teoria.

Quanto à produção de documentos ilegíveis, devem-se evitar narrações prolongadas e relatórios extensos que desencorajam a leitura e análise do estudo de caso, razão que faz necessária uma boa delimitação, com contornos claramente definidos. Pode possuir uma característica similar a outros estudos, mas é ao mesmo tempo distinto, pois tem interesse próprio. Interesse este que deve incidir no único, no 
particular. Ou seja, para os autores supramencionados o estudo de caso passa por um campo exaustivo de uma determinada realidade, de maneira a possibilitar o seu amplo e detalhado conhecimento; destacam ainda que esse tipo de estudo talvez seja um dos mais relevantes para a pesquisa qualitativa. $O$ procedimento de seleção e treinamento deve ser criterioso de modo a assegurar o domínio das habilidades necessárias à realização deste tipo de estudo.

Neste estudo o método de investigação selecionado será o qualitativo, uma vez que existe a preocupação de observar, descrever, interpretar e apreciar o meio e o fenômeno sem procurar controlar, ou seja, "o objetivo desta abordagem de investigação utilizada para o desenvolvimento do conhecimento é descrever ou interpretar, mais do que avaliar" (FORTIN; SALGUEIRO, 1999, p. 22).

\subsection{CARACTERIZAÇÃO DA AMOSTRA}

Uma amostra é uma representação de uma determinada população, sendo sempre o objeto de estudo de qualquer investigação científica.

O processo de seleção de uma amostra, no âmbito de qualquer investigação, requer alguns cuidados metodológicos que a tornem representativa da população alvo a que pertence, como forma de permitir a generalização dos resultados ao universo populacional de que foi retirada.

Fortin e Salgueiro (1999) definem uma amostra como sendo um subconjunto de uma população ou de um grupo de sujeitos que fazem parte da mesma população, sendo que esta é entendida como o conjunto de todos os indivíduos ou outros elementos de um grupo bem definido, que têm em comum uma ou mais características semelhantes, na qual assenta a investigação (FORTIN; SALGUEIRO 1999, p. 202).

\subsubsection{População}

A população da pesquisa são crianças com idades entre 5 a 11 anos, diagnosticada com Transtorno do Espectro Autista, frequentadoras do projeto de extensão - Psicomotricidade Relacional, assistidas pelo Centro de Atenção Psicossocial Infanto Juvenil (CAPSi) no Município de Natal-RN, o qual recebeu uma Declaração de Ciência Institucional (Apêndice A) 
A princípio atendemos todas as crianças sem distinção, mas somente uma criança foi escolhida para o estudo de caso.

A amostra, então, constituiu-se de uma criança obedecendo os seguintes critérios de seleção:

- Ter idade entre 5 e 11 anos;

- Ter sido diagnosticada dentro do Transtorno do Espectro Autista;

- Ter pelo menos $75 \%$ de participação nas sessões;

- Ter sido capaz de responder aos testes motores.

Esta escolha foi realizada mediante a aceitação e a vontade de participar do estudo, sendo nesse caso, a vontade dos pais ou responsável em permitir inclusão da criança na oficina de Psicomotricidade Relacional e execução dos testes motores (EDM e Posturografia) com a assinatura do Termo de Consentimento Livre e Esclarecido - TCLE (Apêndice B), autorizando a participação do mesmo.

\subsubsection{O caso}

O sujeito do estudo de caso é do sexo masculino, com idade de 5 anos. "A" foi o pseudônimo escolhido para que não houvesse exposição do mesmo.

"A" mora na cidade do Natal, no Estado do Rio Grande do Norte e frequenta o Centro de Atenção Psicossocial Infanto Juvenil (CAPSi) no Município de Natal-RN como assistido.

De acordo com informações provenientes de prontuário do CAPSi, na data de 21 de outubro de 2013, após triagem e acompanhamento em consulta médica com psiquiatra, "A" recebeu diagnóstico de Transtorno no Espectro Autista (F-84 na CID10) registrado em prontuário médico.

De acordo com entrevista com a mãe, "A" foi gerado de uma gravidez planejada, e teve acompanhamento pré-natal e sua mãe tinha 28 anos e seu pai 35. Segundo a mãe, a gestação foi tranquila até os 7 meses, quando apresentou hipertensão, a qual foi motivo para iniciar tratamento medicamentoso até o dia do nascimento de "A".

Nas consultas pré-natais nenhuma alteração fetal foi apontada, porém o parto foi uma cesariana em função da hipertensão. 
Ao nascer, "A" chorava muito e reagia com choro quando alguém, que não fosse a sua mãe, o tocasse. Esse comportamento persistiu e até os dois anos continuava chorando na presença de outras pessoas. A mãe relatou que no aniversário de 3 anos com o barulho das pessoas ao cantar parabéns, "A" chorou muito.

Aos cinco "A" apresentava baixa tonicidade muscular, demonstrando assim um corpo muito molinho e não sustentava a cabeça. Preocupada, a mãe o levou ao neurologista, o qual a orientou que estimulasse a criança sentando-a apoiada a almofadas. Ela relatou que "A" sentou aos sete meses, mas não engatinhou e próximo aos 12 meses a criança foi colocada no "anda já" (Andador) e com isso, conseguiu firmar o tronco e começou a andar aos 12 meses.

"A" foi amamentado até os 2 anos e 6 meses, mas a partir do quinto mês começou a tomar mingau alternando com o leite materno e com comidinhas quando liquidificadas, pois não aceitava de outra forma. Deu um pouco de trabalho para o desmame que ocorreu após uma forte gripe em que "A" não quis mais ser amamentado. Aos 3 anos, "A" comia a comida sem está processada, porém os alimentos tinham de estar separados no prato, se a comida se misturasse ele não comia.

"A" apenas balbuciava e falava "Papai", "Mamãe" e "Não", mas gritava muito e sua mãe percebeu que "A" não gostava de outras crianças e tinha o hábito de enfileirar objetos.

Ele iniciou na escola (Centro Municipal de Educação Infantil - CMEI), aos três anos, demorou a se adaptar, mas gostava de ir. "A" não falava, fato este que chamou a atenção dos professores e que orientou aos pais a procurar atendimento no CAPSi.

Em relação ao histórico familiar psicopatológico, o avô materno de " $\mathrm{A}$ " tem epilepsia e na família paterna existe um primo com transtorno psicológico.

"A", depois de diagnosticado dentro do Transtorno do Espectro Autista, recebeu atendimento com psiquiatra, fonoaudiólogo e participou da oficina da brinquedoteca e em 2014.2 na oficina de Psicomotricidade Relacional, a qual teve uma pausa de 4 meses para o início das atividades do semestre 2015.1.

Fora os atendimentos com fonoaudióloga no CAPSi e participação nas oficinas, a rotina de " $A$ " se resume em ir à escola (CMEI), brincar sozinho em casa com seus brinquedos preferidos (carrinhos) e assistir desenhos animados. 


\subsection{APRECIAÇÃO PELO COMITÊ DE ÉTICA EM PESQUISA}

O protocolo de pesquisa foi submetido, analisado e aprovado pelo Comitê de Ética em Pesquisa da Universidade Federal do Rio Grande do Norte/UFRN Campus Central com o número do parecer: 1.131.835, data do Relatório: 26/06/2015 e de acordo com a resolução № 466/12 (Anexo A).

\subsection{VARIÁVEIS DE ESTUDO}

\subsubsection{Variável independente: Psicomotricidade Relacional}

\subsubsection{Variáveis dependentes: Habilidades Motoras e Controle Postural.}

\subsection{PROCEDIMENTOS E INSTRUMENTOS DE COLETAS}

\subsubsection{Sequência Lógica de Execução}

Seguindo uma linha do tempo, tivemos as seguintes sequências de execução:

- 1ㄴ - Avaliação das habilidades motoras com a Escala de Desenvolvimento Motor (ROSA NETO, 2014);

- $2^{\circ}$ - Avaliação do controle postural em Plataforma de Força.

- 3 o - Intervenção com a oficina de Psicomotricidade Relacional por um período de oito semanas com um encontro semanal e duração de 60 minutos.

- 40 - Reavaliação das habilidades motoras com a Escala de Desenvolvimento Motor (ROSA NETO, 2014);

- $5^{\circ}$ - Reavaliação do controle postural em Plataforma de Força;

- 6o - Análise do material audiovisual das sessões com base nos critérios da performance do Teste do Desenvolvimento Motor Amplo - TGMD-2 (ULRICH, 2000). 


\subsubsection{Escala de Desenvolvimento Motor (EDM)}

A Escala de Desenvolvimento Motor (EDM), (ROSA NETO, 2014) avalia o nível de desenvolvimento motor através da avaliação das habilidades motoras (realização da ação motora), classificando suas respectivas aptidões motoras (conjunto de habilidades motoras dada a uma determinada etapa evolutiva) de crianças de 2 a 11 anos. É um instrumento de diagnóstico que permite utilizar um método eficaz para realização de estudos motores. A bateria é bastante diversificada e divertida, prendendo a atenção da criança na sua aplicação. A EDM possui um tempo de aplicação de 30 a 45 minutos numa ordem de aplicação dos seguintes testes: Motricidade fina, Motricidade Global; Equilíbrio; Esquema Corporal (imitação de posturas e rapidez); Organização espacial;

Protocolo de Aplicação da EDM:

A) Motricidade Fina - Pede-se que repita as seguintes ações:

- 2 anos - Construção de uma torre com cubos;

- 3 anos - Construção de uma ponte com 3 cubos;

- 4 anos - Enfiar a linha na agulha;

- 5 anos - Fazer um nó simples;

- 6 anos - Traçar com um lápis uma linha contínua do início ao fim de um labirinto;

- 7 anos - Fazer uma bolinha compacta com um pedaço de papel de seda utilizando uma das mãos;

- 8 anos - Com a ponta do polegar tocar com a máxima velocidade os dedos da mão, um após o outro, sem repetir a sequência;

- 9 anos - Lançar uma bola em um alvo a um metro distância;

- 10 anos - Realizar movimentos sucessivos e regulares de círculo com o polegar;

- 11 anos - Agarrar uma bola.

B) Motricidade Global - Pede-se que repita as seguintes ações:

- 2 anos - Subir sobre um banco de 15cm;

- 3 anos - Saltar sobre uma corda estendida no solo;

- 4 anos - Saltar no mesmo lugar;

- 5 anos - Saltar uma altura de $20 \mathrm{~cm}$; 
- 6 anos - Caminhar sobre uma linha reta;

- 7 anos - Saltar por um percurso retilíneo num pé só;

- 8 anos - Saltar uma altura de $40 \mathrm{~cm}$;

- 9 anos - Saltar sobre o ar flexionando os joelhos tocando os calcanhares com as mãos;

- 10 anos - Saltar por um percurso retilíneo num pé só deslocando uma caixa de fósforo;

- 11 anos - Saltar sobre uma cadeira de $45 \mathrm{~cm}$ (11 anos).

C) Equilíbrio - Pede-se que repita as seguintes ações:

- 2 anos - Equilíbrio estático sobre um banco de $15 \mathrm{~cm}$;

- 3 anos - Equilíbrio com um joelho no chão e a outra perna flexionada à frente;

- 4 anos - Equilíbrio com tronco flexionado;

- 5 anos - Equilíbrio nas pontas dos pés com os olhos abertos;

- 6 anos - Equilíbrio estático em um pé;

- 7 anos - Equilíbrio de cócoras;

- 8 anos - Equilíbrio com o tronco flexionado sobre as pontas dos pés;

- 9 anos - Fazer um quatro utilizando os membros inferiores;

- 10 anos - Equilíbrio na ponta dos pés com os olhos fechados;

- 11 anos - Equilíbrio estático em um pé com os olhos fechados.

D) Esquema Corporal (imitação de posturas e rapidez) - Pede-se que repita as seguintes ações:

- 2 a 5 anos - Imitação de gestos simples: movimentos das mãos e dos braços;

- 6 a 11 anos - Prova de rapidez onde deve-se marcar o máximo de riscos dentro uma folha quadriculada, quadrado por quadrado;

E) Organização espacial - Pede-se que repita as seguintes ações:

- 2 anos - Encaixar peças geométricas em um tabuleiro;

- 3 anos - Mesma tarefa anterior apresentando as peças em posição invertida à do tabuleiro;

- 4 anos - Dê dois palitos de tamanhos e posições diferentes e solicite que o avaliado identifique o mais longo;

- 5 anos - Montar com dois triângulos um retângulo unindo suas hipotenusas;

- 6 anos - Identificação de direita e esquerda;

- 7 anos - Execução de movimentos de acordo com o que o examinador solicita; 
- 8 anos - Reconhecimento sobre outro de acordo com o que o examinador solicita;

- 9 anos - Execução de movimentos feitos pelo examinador sem reprodução em "espelho";

- 10 anos - Reprodução de movimentos através de figuras;

- 11 anos - Reconhecimento da posição relativa a objetos.

F) Organização Temporal (linguagem e estruturas temporais) - Pede-se que repita as seguintes ações:

- 2 anos - Formar frases de duas palavras;

- 3 A 5 anos - Repetir frases de 6 a 7 sílabas solicitadas pelo examinador;

- 6 A 1 anos - Repetição por meio de golpes e desenhos de sons reproduzidos pelo examinador; reprodução por meio de golpes de estruturas observadas no cartão; reprodução por meio de desenhos dos sons golpeados pelo examinador.

- Lateralidade (mãos, olhos e pés)

- Avaliação da lateralidade das mãos: lançar a bola em um alvo, construir uma torre com cubos, escrever ou desenhar;

- Avaliação da lateralidade dos olhos: observar através de um cartão furado e telescópio;

- Avaliação da lateralidade dos pés: chutar uma bola.

\subsubsection{Posturografia em Plataforma de Força}

Posturografia - Utilizou-se uma plataforma de força triaxial da marca Cefise (Figura 1), (instrumento que consiste em uma placa com sensores de força do tipo células de carga ou piezoelétrico instalados sob ela para medir os três componentes de força, Fx, Fy e Fz e os três momentos de força Mx, My e Mz que estão agindo sobre a plataforma) a qual avalia o equilíbrio estático do indivíduo em postura ortostática e que quantifica as oscilações anteroposterior e médio-lateral e o deslocamento do Centro de Pressão (CP) que é o ponto de aplicação resultante das forças verticais agindo sobre a superfície em contato com a base (BARELA; DUARTE 2011). Mediante os dados coletados na Posturografia, pode-se estabelecer uma relação com o controle postural do indivíduo. 
Figura 1 - Plataforma de Força

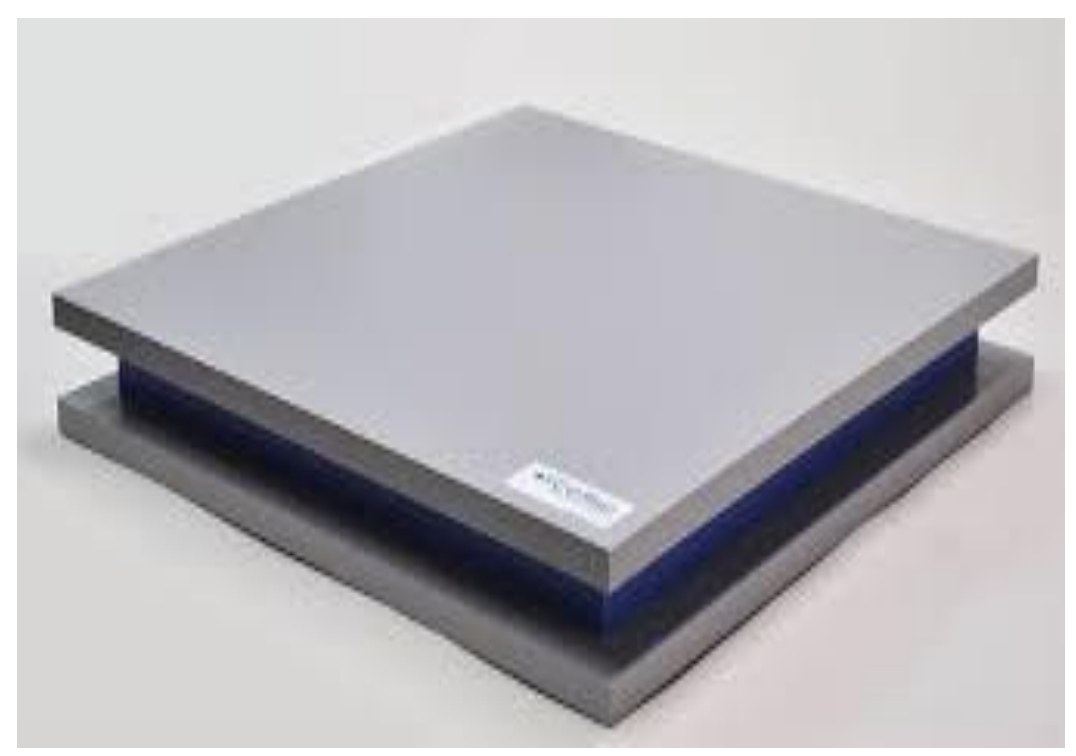

Fonte: http://www.cefise.com.br/produto/50/30/plataforma-de-forca-sv

Protocolo utilizado (adaptado de CHELDAVI et al, 2014): Todos os procedimentos foram realizados no mesmo ambiente. Durante o procedimento de teste, o participante ficou em silêncio na plataforma de força com os pés descalços, posicionados na largura dos ombros e braços ao longo do corpo. O avaliado foi convidado a dirigir sua atenção visual em direção a um pedaço de papelão azul na altura do olhar a 1,5m de distância e estimulado a "brincar" de estátua com o avaliador com a intensão de prender a atenção do avaliado. A sessão consistiu de três capturas em duas condições diferentes: com visão (CV) e sem visão (SV). Enquanto permaneceu nesta posição, o Centro de Pressão (CP) foi captado nas direções anteroposterior (AP) e médio-lateral (ML), a uma taxa de amostragem de $100 \mathrm{~Hz}$ para os ensaios de 30 segundos. Foi feita uma marcação para localizar o pé na plataforma para evitar aferição dar-se sempre no mesmo local.

\subsubsection{Intervenção - Psicomotricidade Relacional}

Foram feitas 08 sessões de Psicomotricidade Relacional descritas em planos de aula (APÊNDICE C) com o objetivo de verificar se esta produz efeitos sobre o perfil das habilidades motoras e sobre o controle postural do indivíduo com Transtorno do Espectro Autista. 
Figura 2 - Imagem do Setting

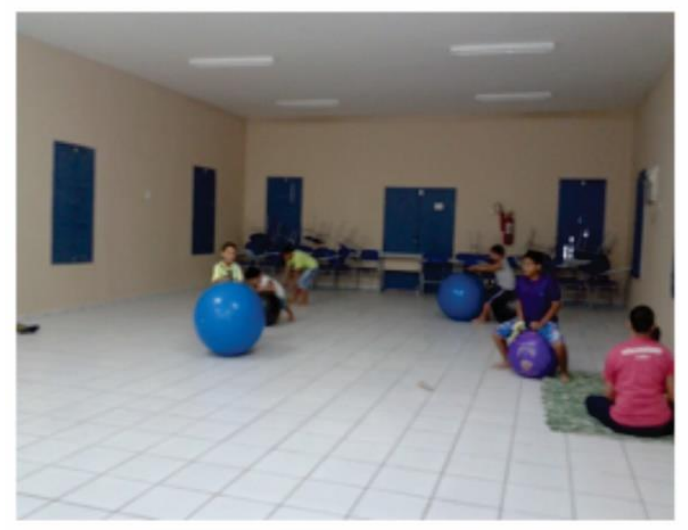

Fonte: registro fotográfico das sessões

Figura 4 - Momento do Brincar

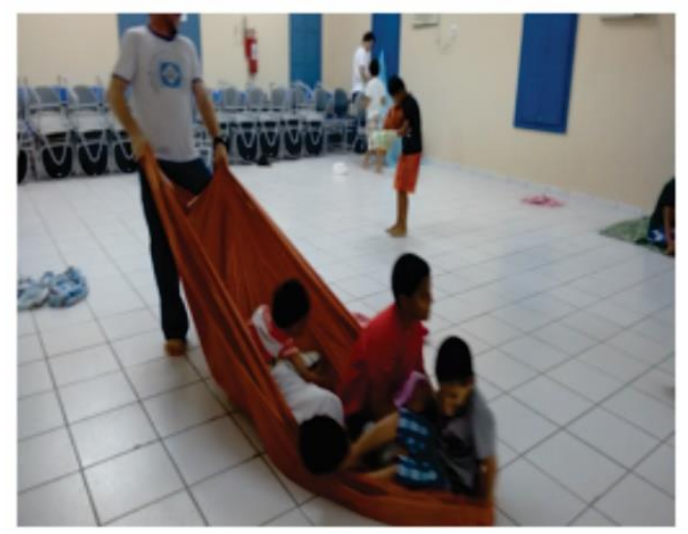

Fonte: registro fotográfico das sessões
Figura 3 - Ritual de Entrada

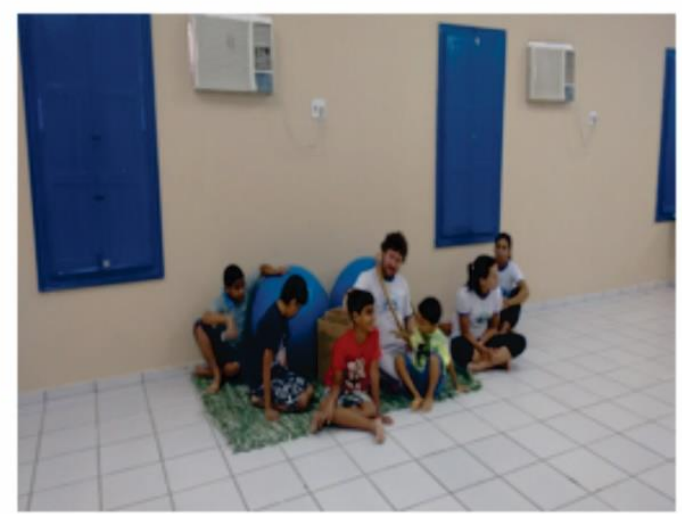

Fonte: registro fotográfico das sessões

Figura 5 - Ritual de Saída

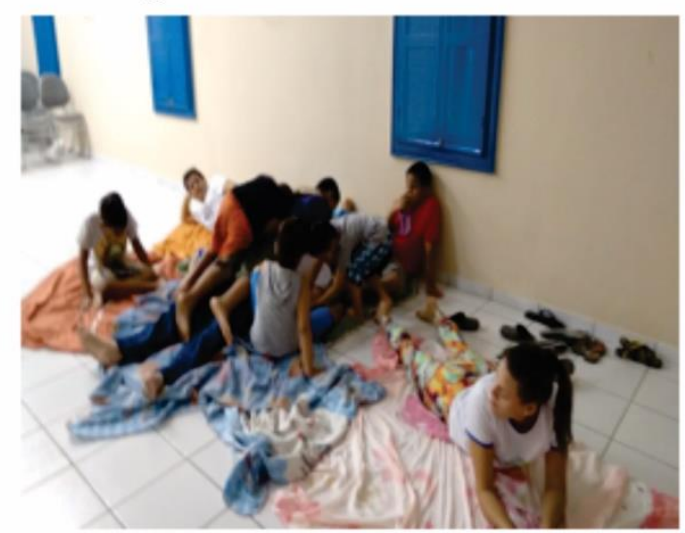

Fonte: registro fotográfico das sessões

As sessões ocorreram em um setting, (Figura 2) - Uma sala em que as crianças puderam transitar livremente - onde as crianças foram convidadas a brincar de forma livre e espontânea, sempre com um brinquedo específico (objeto) e dois professores para que houvesse a interação entre os pares (criança com os objetos, com o colega e com o ambiente). Estas seguem uma rotina identificadas como os rituais de entrada (prepara-se a criança para o brincar) (Figura 3) pelo momento do brincar (oportunidade para as experiências corporais e vivências simbólicas) (Figura 4) e pelos rituais de saída (Figura 5) (FALKENBACH; DIESEL; OLIVEIRA, 2010).

Cada sessão foi registrada através de relatório redigido pelos professores atuantes na sessão.

A sequência das sessões, os respectivos materiais utilizados e os objetivos estão dispostos no quadro abaixo: 
Quadro 01 - Descrição das sessões de Psicomotricidade Relacional

\begin{tabular}{|c|c|c|}
\hline Sessões & Objetos & Objetivos \\
\hline Sessão 1 & Bola & $\begin{array}{l}\text { - Estimular a pulsão de vida/desejos } \\
\text { dos sujeitos, estimulando suas } \\
\text { primeiras inibições. }\end{array}$ \\
\hline Sessão 2 & Arco/Bambolê & $\begin{array}{l}\text { - Estimular a pulsão de vida dos } \\
\text { sujeitos, } \\
\text { Suas inibições e agressividade } \\
\text { pura, delimitando limites e } \\
\text { estruturação espacial. }\end{array}$ \\
\hline Sessão 3 & Corda & $\begin{array}{l}\text { - Explorar a agressividade pura e } \\
\text { simbólica como forma de } \\
\text { comunicação alternativa entre os } \\
\text { pares estimulando a organização } \\
\text { espacial. }\end{array}$ \\
\hline Sessão 4 & Bastão/flutuador & $\begin{array}{l}\text { - Continuar estimulando a pulsão de } \\
\text { vida dos sujeitos, agressividade } \\
\text { pura, simbólica, organização } \\
\text { espacial e temporal. }\end{array}$ \\
\hline Sessão 5 & Caixa & $\begin{array}{l}\text { - Incentivar a agressividade } \\
\text { simbólica, a comunicação, jogos } \\
\text { simbólicos e organização espacial. }\end{array}$ \\
\hline Sessão 6 & Tecido & $\begin{array}{l}\text { - Estimular a comunicação através } \\
\text { do jogo simbólico, equilíbrio } \\
\text { corporal, organização espacial e } \\
\text { temporal. }\end{array}$ \\
\hline Sessão 7 & Jornal & $\begin{array}{l}\text { - Estimular a comunicação através } \\
\text { dos jogos simbólicos e o esquema } \\
\text { corporal. }\end{array}$ \\
\hline Sessão 8 & $\begin{array}{l}\text { Objetos Mistos (Bola, } \\
\text { corda, caixa, jornal, tecido } \\
\text { e bambolê) }\end{array}$ & $\begin{array}{l}\text { - Autonomia dos indivíduos em todas } \\
\text { as aptidões motoras. }\end{array}$ \\
\hline
\end{tabular}




\subsubsection{Análise de vídeo das sessões baseada no Teste Do Desenvolvimento Motor Amplo - Segunda Edição - TGMD-2 (ULRICH, 2000)}

Foi utilizada uma câmera filmadora da marca Sony para fazer o registro audiovisual das sessões, a qual era manipulada por um professor auxiliar. Foi analisada a parte principal das sessões 1 (com o material bola) e 8 (com objetos mistos: bola, corda, caixa, jornal, tecido e bambolê). Optou-se por identificar, em cada sessão, uma cena que representasse de maneira clara a habilidade motora fundamental de locomoção (correr), bem como a representativa do controle de objeto (arremessar) e, utilizando apenas o item "Critérios da Performance" do TGMD-2 (ULRICH, 2000), procurou-se descrever as cenas selecionadas, buscando evidenciar possíveis diferenças na execução das habilidades entre a primeira e última sessão, mas sem utilizar o método de classificação proposto pelo teste.

O TGMD-2 é um teste normativo baseado em critérios para avaliação das habilidades motoras fundamentais em crianças de 3 a 10 anos, no qual inclui-se duas subescalas: o controle da locomoção e o de objetos.

Cada habilidade motora fundamental é avaliada sob três a cinco critérios de performance, que recebem uma pontuação: 0 (não atende os critérios da performance) e 1 (atende os critérios da performance) e ao final, soma-se todos os números, dando um resultado entre 0 e 48 pontos para a subescala de locomoção e, de maneira igual, para a subescala de controle de objetos. O escore encontrado serve para calcular valores-padrão e desconsidera a idade da criança para que se possa comparar com outras de idades diferentes. O teste também permite classificar 0 resultado por percentil, baseado na idade e no sexo da criança, de modo que uma classificação elevada dessa forma diz que o indivíduo é competente no que se refere aos aspectos motores e uma classificação abaixo de 25 é considerada atrasada nos níveis de desenvolvimento. 


\subsection{TRATAMENTO DOS DADOS}

As sessões foram registradas através de relatório redigido pelos professores participantes, no qual foram pontuadas impressões sobre a sessão bem como as informações verbais, não verbais e contextuais. Ele é de grande utilidade, visto que Ihe é permitido anotar também todas as suas sensações e emoções que surgem em determinados momentos. Esses registros apresentam-se importantes para o processo de análise dos dados, pois complementam os dados levantados através dos outros instrumentos utilizados.

Os dados da Escala de Desenvolvimento Motor (EDM) foram tabulados, calculados e classificados conforme a própria escala.

Os registros da posturografia durante as três tentativas de teste foram processados utilizando MatLab R2013b. Foi usado um filtro Butterworth de quarta ordem. Foram selecionadas para discussão dos dados as variáveis temporais: amplitude média de oscilação anteroposterior (AmCPap) e a amplitude média de oscilação médio-lateral (AmCPml) e o deslocamento total (Dt) nas condições com visão e sem visão, todos medidos em $\mathrm{cm}$, apresentados de forma descritiva e calculadas suas variações através do delta percentual $(\Delta \%)$ entre os momentos pré e pós-intervenção.

Foram selecionadas cenas que representassem habilidades motoras básicas de locomoção e manipulação de objetos, a fim de comparar a execução do movimento da primeira e da última sessão, sendo analisado qualitativamente conforme os critérios de Ulrich (2000). 


\section{RESULTADOS E DISCUSSÃO}

É importante que tenhamos consciência que na realização de trabalhos com indivíduos com Transtorno do Espectro Autista não encontraremos dois casos com as mesmas características, pois seus comportamentos são particulares e únicos, o que faz com que encontremos no máximo comportamentos similares. Além disso, o universo em que o indivíduo está inserido será condicionante para caracterizar suas respostas e comportamentos à intervenção (ANDRADE, 2012).

O indivíduo "A", com cinco anos de idade, reside na cidade do Natal, estado do Rio Grande do Norte, assistido pelo CAPS-i de Natal, foi diagnosticado dentro do Transtorno do Espectro Autista e participou de seis de oito sessões de Psicomotricidade Relacional (referente a $75 \%$ de participação).

\subsection{AVALIAÇÃO DAS HABILIDADES MOTORAS}

Para a avaliação das habilidades motoras, utilizamos a bateria de testes motores da Escala de Desenvolvimento Motor (EDM). Esta utiliza testes motores baseados nas habilidades motoras, classificando as aptidões motoras do indivíduo. Os resultados são dados em Idade motora (meses) e quocientes motores (valores numéricos). Os valores numéricos dos quocientes motores classificam os níveis da EDM, a qual permite uma classificação das habilidades motoras estudadas em padrões: "muito superior (130 ou mais), superior (120-129), normal alto (110-119), normal médio (90-109), normal baixo (80-89), inferior (70-79) e muito inferior (69 ou menos)".

Os resultados dos testes motores (aptidão motora) para cada habilidade foram dados em meses, calculando-se posteriormente seus respectivos quocientes motores e classificados com base na própria EDM. Os resultados foram apresentados através de uma análise descritiva, permitindo a observação das diferenças dos resultados nos momentos antes e após as avaliações, sendo expostos em: Idade Cronológica (IC), Idade e o Quociente Motor Geral (IMG e QMG) e Idades e Quocientes Motores (IM e $\mathrm{QM})$ específicos para cada área motora. 
Figura 6 - Gráfico da Idade Cronológica, Idade Motora Geral, Idade Negativa e Quociente Motor

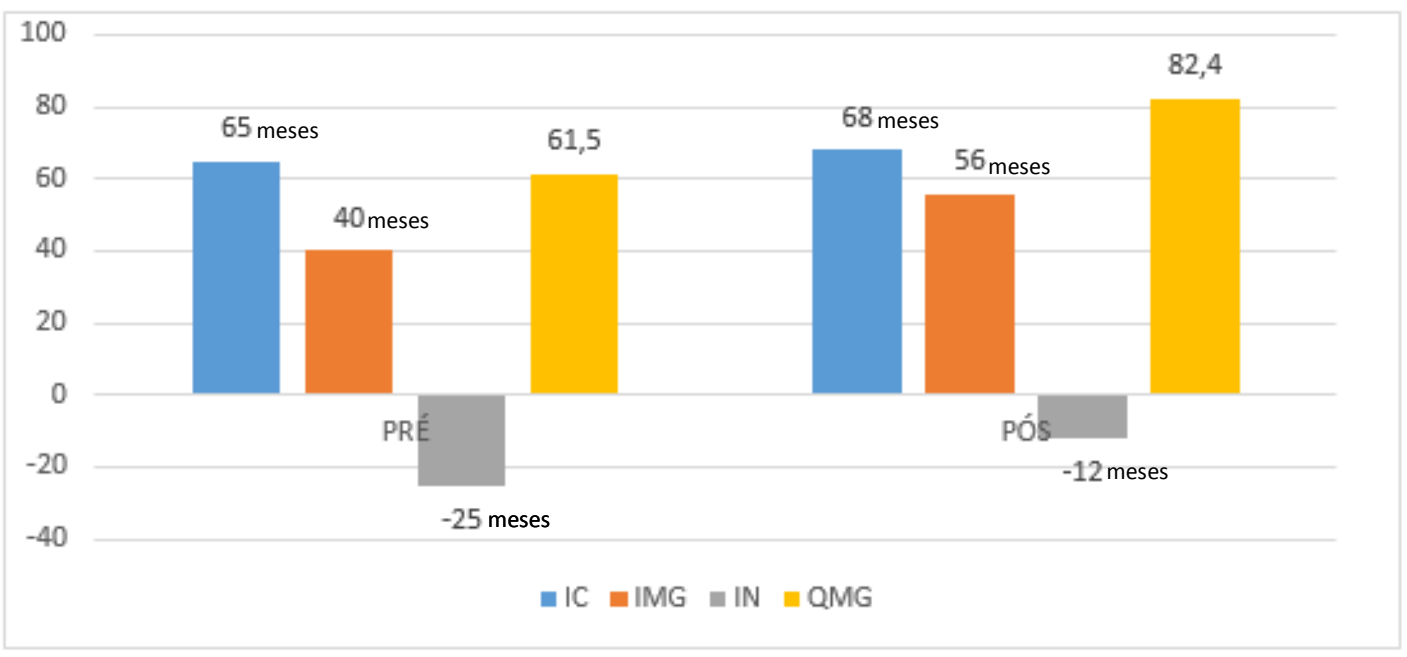

Legenda: Idade Cronológica (IC), Idade Motora Geral (IMG), Idade Negativa (IN) e Quociente Motor Geral (QMG)

A figura 6 aponta que a Idade Cronológica (IC) da criança era de 65 meses no pré-teste e 68 meses no pós-teste e a Idade Motora Geral (IMG) era de 40 meses no pré-teste e passou para 56 no pós-teste, ou seja, houve um aumento de 16 meses. A diferença entre a IMG e a IC resulta numa Idade Negativa (IN) ou Idade Positiva (IP), sendo a primeira uma indicativa de atraso no desenvolvimento. Foi observada a presença de uma idade negativa em ambos os momentos de avaliação, já que a IC foi superior nos dois instantes. Porém, nota-se alterações importantes nos valores da IN, que passaram de -25 meses no pré-teste para -12 meses no pós-teste, o que favoreceu a diminuição no atraso em relação à IC e indica um progresso no desenvolvimento da criança.

Ainda na figura 6, quando olhamos para o Quociente Motor Geral (QMG), podemos reafirmar o avanço no desenvolvimento motor apresentado por essa criança, que foi classificado como "muito inferior" no momento pré e "normal baixo" no momento pós-intervenção. Okuda, Misquiatti e Capellini (2010), apropriando-se também da EDM como ferramenta de avaliação, procuraram fazer uma caracterização do perfil motor de estudantes com Transtorno do Espectro Autista. Tal estudo, realizado com seis indivíduos com idade entre 5 e 10 anos, que apresentavam, também, prejuízos nos desempenhos acadêmico, social e de lazer, identificou que $50 \%$ das crianças estudadas apresentavam desenvolvimento motor muito inferior e $16,6 \%$ inferior, além de que as idades motoras diferem em cada uma das habilidades 
avaliadas. Mas, estudos indicam as intervenções psicomotoras como métodos eficazes na melhora das habilidades motoras de indivíduos com Transtorno do Espectro Autista. Lima et al. (2014), analisando 21 crianças com idade média de 3 anos, identificaram uma evolução em quase todas as áreas do desenvolvimento motor desses indivíduos após a inserção destes em um programa de intervenções que tinha como uma das especialidades a psicomotricidade. Já Rosa Neto (2013), em um estudo de 15 semanas, verificou os efeitos de intervenções motoras em uma menina de 9 anos diagnosticada com Transtorno do Espectro Autista, executadas em duas sessões semanais com duração de 50 minutos, e demonstrou que a intervenção foi capaz de promover melhoras aos níveis das habilidades motoras da criança, o que foi perceptível através do registro de ganhos avaliados sob a EDM, embora tenham sido apontadas dificuldades motoras na criança.

Este resultado nos encaminha para considerarmos que a intervenção psicomotora abordada em nosso estudo, com caráter relacional, proposta a partir da ideia do brincar, dos jogos simbólicos e da movimentação corporal espontânea, pode ser uma ferramenta para melhorar os níveis das habilidades motoras nas crianças com o Transtorno do Espectro Autista, as quais encontram-se com atraso. A movimentação e o brincar, facilmente podem ser identificados nas falas dos professores registradas nos relatórios das sessões: "observou-se que algumas crianças se permitiram vivenciar aquele momento, gastando muita energia, extravasando seus sentimentos..." (RELATÓRIO SESSÃO BOLA).

“...um aspecto que dificultou a vivência do jogo simbólico e a livre expressão foi a tentativa constante e planejada de impor limites espaciais e temporais às crianças. Esse enfrentamento me levou quase a exaustão" (RELATÓRIO SESSÃO BAMBOLÊ)

O Brincar e a pulsão de movimento ativam a criatividade e o desejo de ser, o que permitirá a aquisição da força, da resistência, da coordenação, do equilíbrio do corpo (VIEIRA; BATISTA; LAPIERRE, 2005). Percebe-se que as sessões de Psicomotricidade Relacional suportam a descrição de uma atividade física quanto à oferta de gerar movimentação dos corpos. Falkenbach, Diesel e Oliveira (2010) em um estudo de caso com uma criança com Transtorno do Espectro Autista que objetivou investigar o brincar nas situações de exercício e de jogo durante as sessões de Psicomotricidade Relacional, consideraram que as sessões beneficiam crianças 
com Autismo e aumentam seus movimentos e suas vivências do brincar, promovendo uma relação mais afetiva com os professores e outras crianças.

Abaixo, na figura 7, encontramos os escores das idades motoras. Pode-se observar as idades para cada habilidade motora antes e após as intervenções. Na análise das habilidades motoras da criança, em cada tarefa, foram verificados avanços importantes nas idades relativas à motricidade fina (IM1), à motricidade global (IM2), ao esquema corporal (IM4) e à organização temporal (IM6); houve manutenção das idades motoras referentes ao equilíbrio (IM3) e um decréscimo na organização espacial (IM5). Esses avanços nas idades motoras resultam em um aumento da Idade Motora Geral (IMG) o que interfere diretamente na Idade Negativa (IN), nesse caso ocorrendo uma diminuição do atraso motor.

Figura 7 - Gráfico das idades motoras em cada habilidade motora.

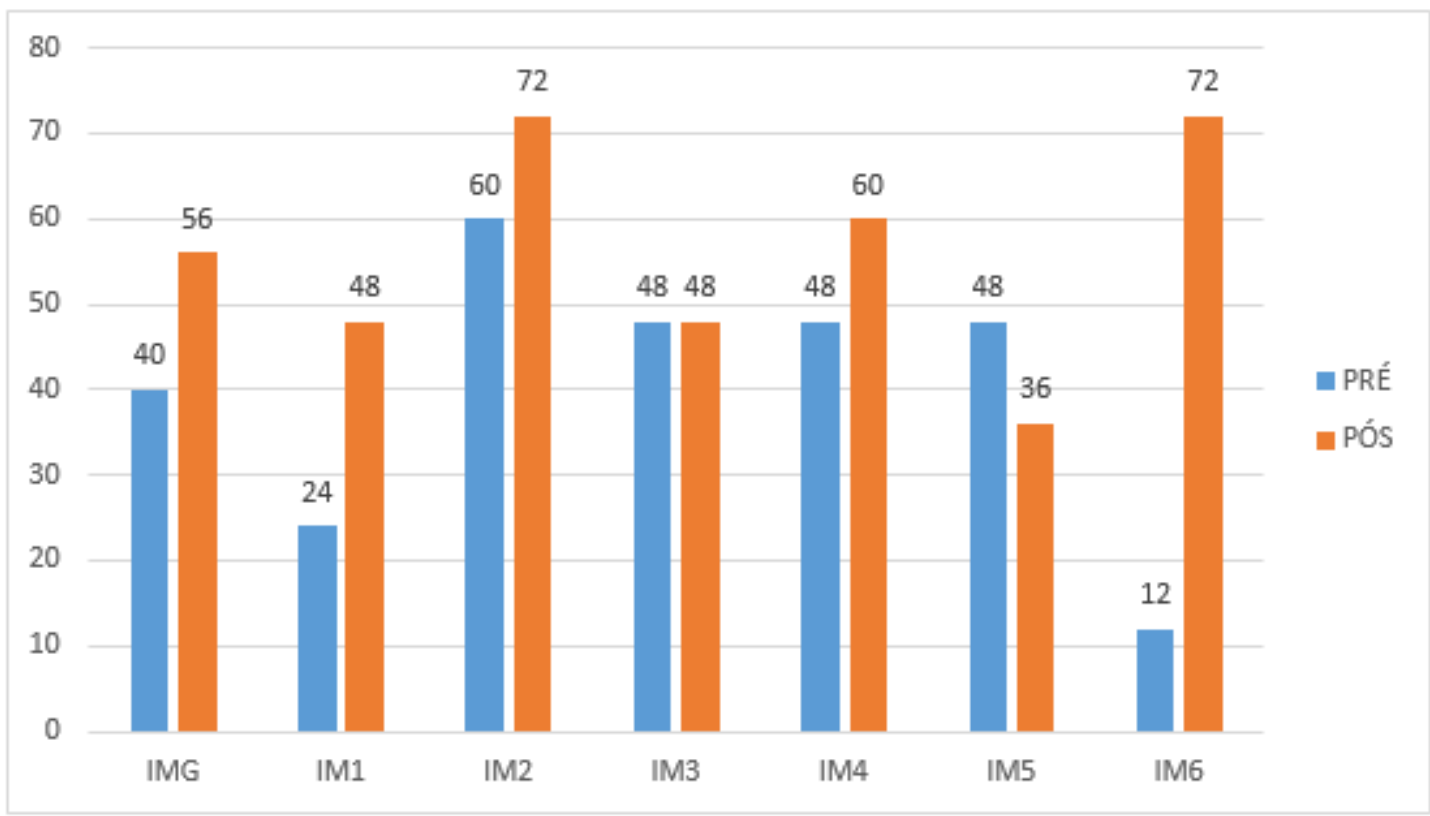

Legenda: Idade Motora Geral (IMG), Idade Motora da Motricidade Fina (IM1), Idade Motora da motricidade Global (IM2), Idade Motora do Equilíbrio (IM3), Idade Motora do Esquema Corporal (IM4), Idade Motora da Organização Espacial (IM5), Idade Motora da Organização Temporal (IM6).

Os resultados dos quocientes motores referentes a cada habilidade motora, conforme figura 8 (abaixo), também demonstram importantes avanços, como o aumento dos quocientes na maioria das habilidades motoras, exceto no equilíbrio, que continuou classificada como "inferior" nos dois momentos (pré e pós) e na organização espacial que teve escores diminuídos, passando a ser classificada de "inferior" para "muito inferior". 
Embora a maioria dos resultados tenham se apresentado com evolução positiva, o resulta no pré-teste da Organização Temporal (IM6) pode expressar os déficits de atenção que acometem o indivíduo com Transtorno do Espectro Autista, uma vez que a criança no pré-teste, nessa habilidade, pode não ter expressado sua capacidade total. O transtorno do Espectro Autista tem sido associado a prejuízos relacionados a atenção, descritos na DSM-5 (CARREIRO et al, 2015).

Deve-se deixar clara a informação de que o que diferencia o Quociente Motor da Idade Motora é que o primeiro considera a Idade Cronológica, enquanto a Idade Motora não.

Figura 8 - Gráfico dos Quocientes motores em cada habilidade motora

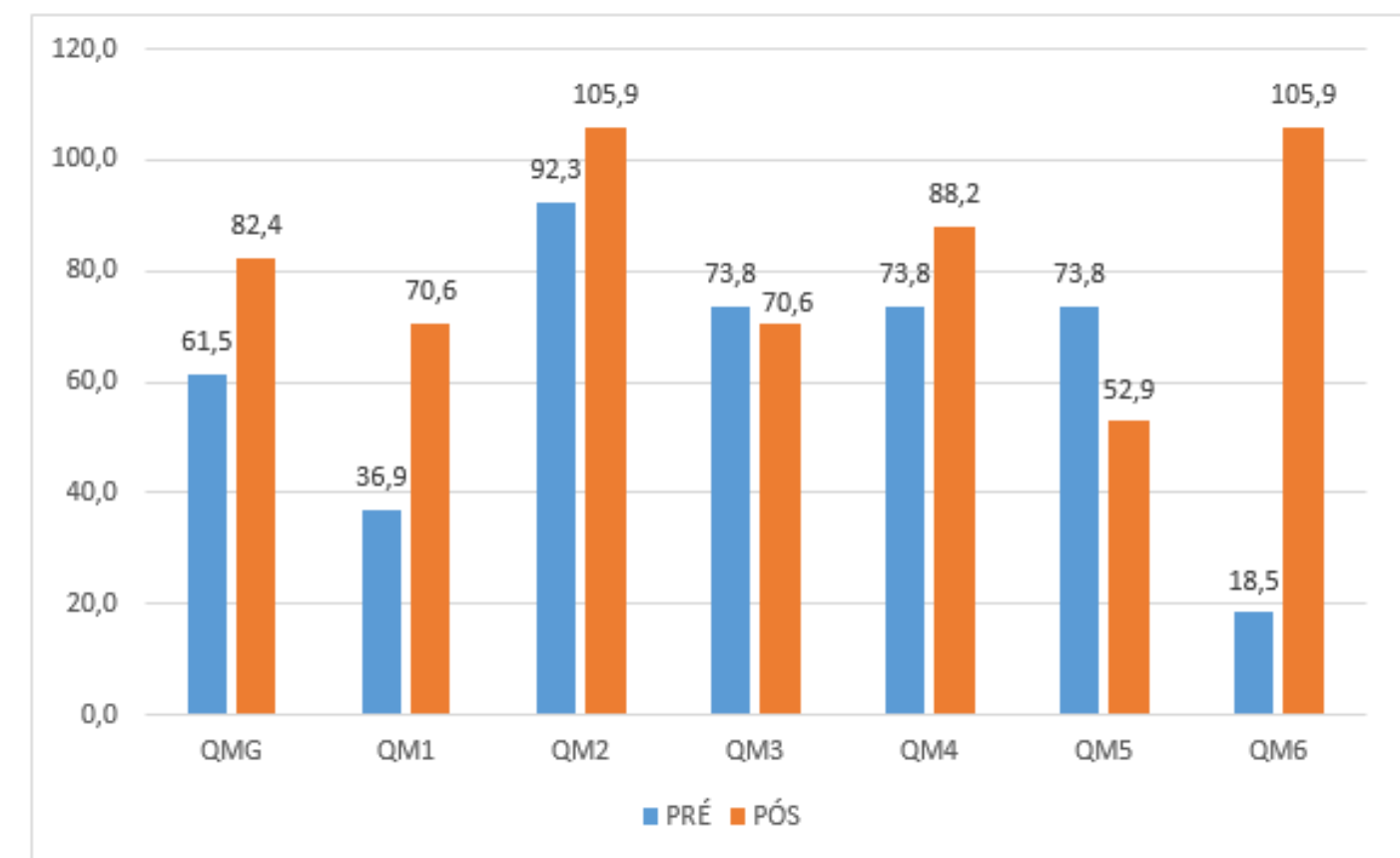

Legenda: Quociente Motor Geral (QMG), Quociente da Motricidade Fina (QM1), Quociente Motor da motricidade Global (QM2), Quociente Motor do Equilíbrio (QM3), Quociente Motor do Esquema Corporal (QM4), Quociente Motor da Organização Espacial (QM5), Quociente Motor da Organização Temporal (QM6)

As sessões de Psicomotricidade Relacional mostraram-se favoráveis para a movimentação corporal bem como para o fortalecimento das relações sociais, dos domínios perceptíveis e da autonomia do sujeito. Percebemos isso com as observações pontuadas nos relatórios:

Senti que a sessão correu melhor do que a sessão com bola, pois notei que as crianças interagiram durante a sessão por mais tempo, bem como aceitaram melhor brincar em grupo.

...observou-se que as crianças se envolveram de forma mais participativa. 
Vale ressaltar, também, que a socialização, a interação entre os colegas, foi percebida em muitos momentos durante a brincadeira (RELATÓRIO SESSÃO BAMBOLÊ).

...a autonomia da maioria das crianças torna-se muito evidente nesta sessão. Percebeu-se que quase todos brincaram sem precisar ser incentivados pelo professor. Pelo contrário, eles vinham buscar o professor já brincando.

... ao pensar nas diversas situações vividas na sessão de jornal uma palavra que mais marcou foi autonomia (RELATÓRIO - SESSÃO JORNAL).

Indivíduos com Transtorno do Espectro Autista têm dificuldades de compreensão do seu corpo em sua totalidade, visto que não são desenvolvidas, de maneira adequada, as noções de esquema corporal (FERNANDES, 2008). Porém, os resultados da EDM apontaram para uma melhora dessa área motora no indivíduo analisado, sugerindo que esse foi sensível à intervenção. Essa melhora no Esquema corporal, apontada pelo teste, pode ser percebida nos desenhos produzidos por "A" ao final de cada sessão.

Conforme quadro 02, percebe-se que a criança insistiu na reprodução do desenho de um corpo que pode ser o seu próprio ou de outra pessoa e apesar do desenho do corpo não se apresentar de forma completa e detalhada, percebe-se uma evolução nos elementos presentes nesse corpo desenhado. Devo lembrar que o indicativo do desenho, aqui, não está pautado na interpretação simbólica desse "personagem", mas no seu formato quando se trata de esquema corporal e sua representação, ou seja, na percepção de "A" sobre a composição do corpo e suas partes.

Quadro 02 - Desenhos da Criança e suas Descrições

\begin{tabular}{|l|l|l|}
\hline \multicolumn{1}{|c|}{ Sessão } & Desenho & \multicolumn{1}{|c|}{ Descrição do Desenho } \\
\hline Bola & $\begin{array}{l}\text { Este desenho sugere um } \\
\text { corpo que se apresenta } \\
\text { com uma cabeça } \\
\text { (círculo), tronco e } \\
\text { membros em forma de } \\
\text { traços, pouco estruturado. }\end{array}$ \\
\hline
\end{tabular}




\begin{tabular}{|c|c|c|}
\hline Arco/Bambolê & 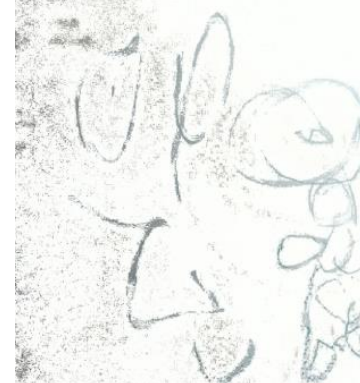 & $\begin{array}{l}\text { Aqui, temos um corpo que } \\
\text { tomou formas maiores, } \\
\text { arredondadas com } \\
\text { braços, pernas, pés e um } \\
\text { nariz ou um olho na } \\
\text { cabeça. }\end{array}$ \\
\hline Bastão/flutuador & 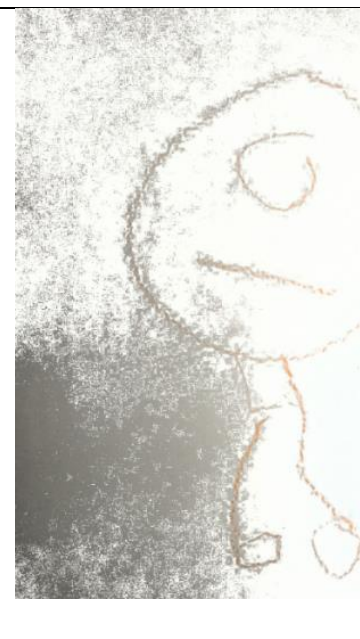 & $\begin{array}{l}\text { Este desenho, nos } \\
\text { apresenta um corpo no } \\
\text { qual na cabeça (Face) há } \\
\text { um olho ou um nariz, uma } \\
\text { boca e o tronco agora } \\
\text { representado como um } \\
\text { quadrado, sem braços, } \\
\text { mas com pernas e pés } \\
\text { bem localizados; }\end{array}$ \\
\hline Caixa & & $\begin{array}{l}\text { Este desenho do corpo, } \\
\text { possui uma cabeça com } \\
\text { um traço sugestivo de } \\
\text { uma boca, possui um } \\
\text { tronco, braços e pernas; }\end{array}$ \\
\hline
\end{tabular}




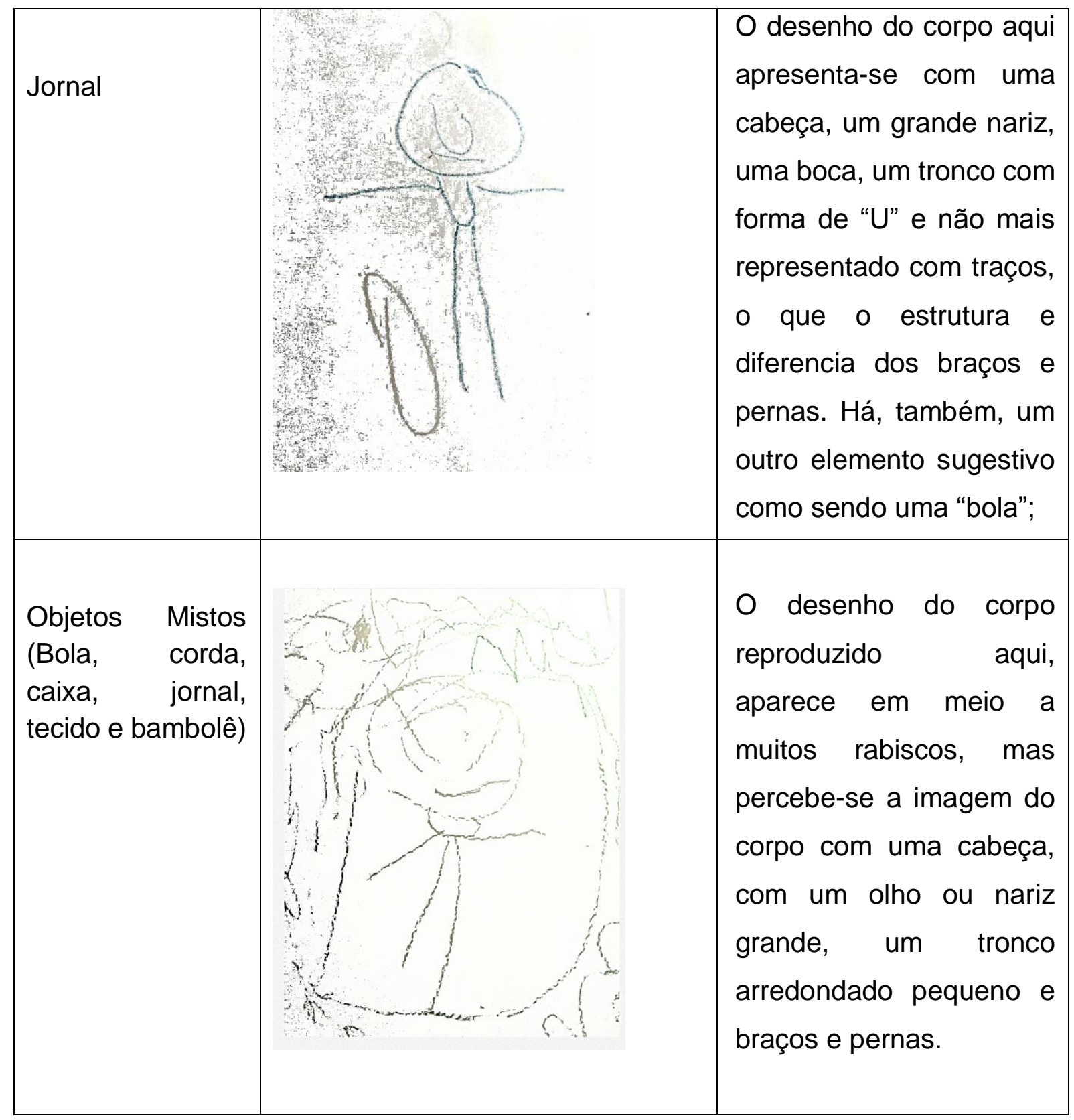

Quando se observa a diferença entre os desenhos, percebe-se uma melhor estrutura e localização das partes do corpo desenhado, o que demonstra uma evolução na percepção de "A" sobre a estrutura corporal. Em proporção, o penúltimo desenho está mais elaborado e mais organizado, quando observamos a localização de cada parte do corpo em relação aos demais desenhos, corroborando com os melhores resultados no pós-teste na EDM na habilidade do Esquema Corporal. A psicomotricidade permite à criança, durante a infância, a descoberta do próprio corpo, do corpo do outro e do ambiente em que está inserida, o que possibilita a organização de suas habilidades (LAPIERRE; AUCOUTURIER, 2004). 
A intervenção psicomotora no autismo tem como um dos seus objetivos o desenvolvimento dos processos cognitivos e que através do brincar, das vivências e experiências motoras, torna-se possível sua concretização (DORNELES; BENETTI, 2012).

Os resultados encontrados no estudo são ratificados em outros estudos que, apesar de não utilizarem a Psicomotricidade Relacional como método, estudaram os efeitos de outras intervenções motoras sobre o perfil das habilidades motoras em crianças com Transtorno do Espectro Autista e outros tipos de transtorno. Em exemplo disto, Prestes (2009) mostrou que 24 sessões de intervenção motora trouxeram benefícios a uma criança com seis anos de idade, portadora de Transtorno do Espectro Autista, nos seguintes aspectos: idade motora, quocientes motores geral, do equilíbrio e do esquema corporal e consequente diminuição em sua idade negativa. Já Rosa Neto (2013), indicou melhorias no ponto de vista da motricidade fina, motricidade global, equilíbrio e esquema corporal em uma criança com nove anos de idade cronológica também acometida com Transtorno do Espectro Autista.

A lateralidade do indivíduo foi definida como cruzada nos dois momentos dos testes da EDM. Fonseca (2007) relata que há uma ligação entre a má lateralidade (cruzada ou indefinida) e as dificuldades motoras (dislexia, gagueira, problemas de estruturação temporal e espacial e problemas relacionados ao esquema corporal), sendo a lateralidade importante para o desenvolvimento da criança.

A lateralidade é um dos aspectos importantes para o desenvolvimento das capacidades de aprendizagem e uma das variáveis do desenvolvimento psicomotor. Há uma forte relação entre lateralidade cruzada e dificuldades na aprendizagem, bem como desabilidades na leitura e confusão na dominância lateral (ROSA NETO, 2013).

Essa informação vai ao encontro de uma característica apontada no prontuário do sujeito, que informa que a criança "não fala". O que reforça o trabalho de estímulo psicomotor. Essas dificuldades motoras surtem efeitos nas atividades diárias da criança com Transtorno do Espectro Autista. Uma vez que a função motora exerce uma fundamental importância para as áreas do desenvolvimento e isso engloba a linguagem, a interação social e a aprendizagem (JESTE, 2011). 


\subsection{AVALIAÇÃO DO CONTROLE POSTURAL}

Os dados da plataforma de força foram tratados no programa METLAB e foram analisados a partir do delta percentual de variação $(\Delta \%)$ dos valores pré e pósintervenção.

Tabela 1 - Amplitude média de Oscilação do Centro de Pressão nas direções ap e ml e Deslocamento do Centro de Pressão Total e Delta Percentual $(\Delta \%)$.

\begin{tabular}{|c|c|c|c|c|}
\hline VARIÁVEL & CONDIÇÕES & $\begin{array}{l}\text { PRÉ-TESTE } \\
\text { (cm) }\end{array}$ & $\begin{array}{l}\text { PÓS-TESTE } \\
\text { (cm) }\end{array}$ & $\Delta \%$ \\
\hline \multirow{2}{*}{ AmCPap } & CV & 0,3496 & 0,2993 & $-14 \%$ \\
\hline & SV & 0,3797 & 0,3788 & $0 \%$ \\
\hline \multirow{2}{*}{ AmCPml } & CV & 0,2767 & 0,2508 & $-9 \%$ \\
\hline & SV & 0,2856 & 0,2484 & $-13 \%$ \\
\hline \multirow{2}{*}{ Dt } & $\mathrm{CV}$ & 1462,1442 & 1316,4901 & $-10 \%$ \\
\hline & SV & 1719,4123 & 1268,0392 & $-26 \%$ \\
\hline
\end{tabular}

Legenda: AmCPap - Amplitude Média do Centro de Pressão no sentido anteroposterior, AmCPml Amplitude Média do Centro de Pressão no sentido médio-lateral, Dt - Deslocamento Total; CV - com visão, SD - sem visão.

A partir das oscilações do Centro de Pressão (CP), as seguintes variáveis foram avaliadas: Amplitude média de oscilação do Centro de Pressão no sentido anteroposterior (AmCPap); Amplitude média de oscilação do Centro de Pressão no sentido médio-lateral (AmCPml) e Deslocamento Total (Dt).

No geral, a literatura sobre o controle postural dos indivíduos com Transtorno do Espectro Autista, avaliados através da plataforma de força, apontam déficits. Estudos demonstram diferenças no controle postural e maiores oscilações na posição ereta e parada nas direções anteroposterior e médio-lateral quando comparadas com crianças e adolescentes de desenvolvimento típico (FOURNIER et al., 2010; MOLLOY; DIETRICH; BHATTACHARYA, 2003). Memari et al. (2013) compararam os padrões de oscilação postural de 21 meninos com Transtorno do Espectro Autista, 
estudantes de escolas específicas para portadores desse transtorno, com os de crianças com desenvolvimento típico: as crianças com Transtorno do Espectro Autista mostraram uma maior instabilidade com maior quantidade de oscilações posturais que crianças com desenvolvimento típico. O estudo também apontou que a taxa de gravidade dos sintomas do autismo afeta significativamente a oscilação postural destas crianças.

Porém, observando a tabela 1 percebemos que, após a intervenção proposta neste estudo, houve diminuição na variação das oscilações do CP em quase todas as variáveis analisadas (CPap, CPml e Dt) nas duas condições, exceto na condição SV na variável AmCPap, a qual apresentou resultados próximos do zero (pré: 0,3797 e pós: 0,3788 ) e delta percentual de variação igual a $0 \%$, ou seja, não houve alteração que vem a ser um valor que não trouxe prejuízo, podendo ser, também, uma possibilidade de explicação para o resultado encontrado do equilíbrio na EDM, demostrada através de uma não alteração na sua classificação (pré: inferior e pós: inferior).

A capacidade do controle postural é importante para o desenvolvimento das habilidades motoras fundamentais (TRAVERS et al, 2013) visto que nas atividades motoras, deve-se ter uma coordenação entre a postura e o movimento com o intuito de que se alcance o objetivo da tarefa (SILVA, 2016) e indivíduos com Transtorno do Espectro Autista enfrentam dificuldades no controle postural em determinados momentos durante seu desenvolvimento. Essa dificuldade pode ser apontada como fator para o desenvolvimento atípico das habilidades motoras fundamentais e sociais do indivíduo com Transtorno do Espectro Autista (BHAT; LANDA; GALLOWAY, 2011).

O Dt é o resultado de todo o trajeto do CP durante o tempo de teste. A tabela 1 mostra uma diminuição da oscilação do CP no Dt em ambas as condições de teste (SV: - 26\% e CV: - 10\%). Com isso, percebemos uma sensibilização do controle postural após a intervenção na posição semi-estática. Tal resultado suporta considerarmos que a intervenção com as sessões de Psicomotricidade Relacional, promoveu no indivíduo avaliado um avanço no que se refere ao controle postural, uma vez que os resultados da variação pós-teste nos apresentam, em percentual, uma variação com diminuição da oscilação corporal.

Por se tratar de uma intervenção em que os movimentos durante a sessão não são controlados, cadenciados ou direcionados a uma especificidade, pois a 
movimentação corporal do indivíduo é espontânea e livre, percebemos que os resultados do presente estudo corroboraram com estudos específicos para o controle postural.

Cheldavi et al (2013) em seu estudo que objetivava investigar os efeitos do treinamento específico para o equilíbrio em indivíduos com TEA, apontou que sua intervenção promoveu um maior controle postural em crianças com Transtorno do Espectro Autista, apontando diminuição nos escores avaliados. A estabilidade postural adequada é um fator inerente ao movimento e base para o desenvolvimento motor e para o desempenho das atividades da vida diária (WESTCOTT et al., 1997; D'HONDT et al, 2011).

\subsection{ANÁLISE DE HABILIDADES MOTORAS NO SETTING DA PSICOMOTRICIDADE RELACIONAL}

Foram selecionadas, através do registro audiovisual, cenas em que se identificaram as habilidades motoras fundamentais de locomoção (corrida) e controle de objetos (arremesso), a fim de exemplificar a presença da movimentação corporal na Psicomotricidade Relacional e a análise da execução das habilidades motoras na primeira e última sessão.

Tomando como base os critérios da performance do Teste Do Desenvolvimento Motor Amplo - Segunda Edição - TGMD-2 (ULRICH, 2000), foi selecionada uma cena da sessão 01 e uma cena da sessão 08, com o objetivo de evidenciar possíveis diferenças na execução das habilidades motoras fundamentais da locomoção (corrida) e do controle de objeto (arremessar) as quais foram descritas e analisadas por dois profissionais de educação física. As duas análises foram comparadas a fim de demonstrar o nível de concordância e confiabilidade na presença ou ausência dos critérios de performance elencados por Ulrich (2000).

Foram identificadas $100 \%$ de concordância em todas as cenas analisadas (Corrida e arremesso nas sessões 01 e 08). Os profissionais apontaram as mesmas presenças e ausências dos critérios de performance. As descrições e análise a seguir foram a partir das duas avaliações.

Cenas de Locomoção: Sessão 01 - minuto 40'00" 
Descrição da cena: A criança correu ao longo do setting sem buscar algo ou alguém específico.

Análise: A criança corre demonstrando uma descoordenação entre braços e pernas, com braços estendidos, pernas estendidas, pouco flexionada e a pisada chapada, com o pé inteiro ao chão; a fase aérea da corrida apresenta-se muito curta.

Sessão 08 - minuto 24'37"

Descrição da cena: A criança correu pelo setting.

Análise: A criança apresenta um pouco de coordenação dos braços com as pernas (move-se em oposição), os braços se apresentam estendidos e pouco flexionados, porém a criança apresenta na corrida extensão e flexão de quadril e joelhos, com uma maior fase aérea e o apoio dos pés na pisada mais concentrado do meio à ponta do pé.

Quando comparamos as análises, percebemos que a da sessão 01 indica uma falta de eficiência na execução da habilidade de correr, enquanto a análise da cena na sessão 08 evidencia que houve uma melhor execução da habilidade motora fundamental de locomoção. Indica-se com isso, que as sessões de Psicomotricidade Relacional proporcionaram movimentação corporal e estímulo para aprimorar a execução da habilidade motora em questão.

O desenvolvimento das habilidades motoras beneficia a criança, uma vez que amplia sua criatividade, estimula sua autoconfiança, diminuindo a suscetibilidade à ansiedades e depressões (MILTEER, 2012). A corrida, extensão do caminhar, é, possivelmente, a habilidade motora fundamental mais importante, visto que é utilizada em quase todos os esportes, atividades infantis e nas atividades ao longo da vida, e que é uma das primeiras habilidades em que a criança apresenta eficiência na realização (GALLAHUE; OZMUN; GOODWAY, 2008).

As crianças desenvolvem suas habilidades e exploram seus limites através dos jogos não estruturados (MILTEER, 2012). Nas sessões de Psicomotricidade Relacional percebe-se a presença de uma dinâmica na movimentação corporal apresentada através das brincadeiras espontâneas, dos jogos simbólicos expressos nas corridas de pega-pega, ou na interação com os objetos da sessão e seus pares.

Cenas de manipulação do objeto:

Arremessar - Sessão 01 - 07'08" 
Descrição da cena: A criança segura duas bolas nas mãos. Em seguida dá uma leva agachada, volta a posição ereta e executa o arremesso da bola que está na sua mão esquerda por cima do ombro de forma desajeitada. Imediatamente após, arremessa a outra bola com sua mão direita, porém utilizando desta vez o auxílio da outra mão.

Análise: A criança executa uma elevação com o objeto nas mãos no momento em que se inicia o arremesso, no qual o movimento da mão/braço acontece de baixo para cima na altura do ombro; evidencia-se que não há movimentação do quadril de maneira oposta ao braço que arremessa (corpo permanece para frente). Além disso, os pés permanecem fixos ao solo (base estacionária).

Sessão 08 - 26'58"

Descrição da cena: A criança se locomove com um jornal amassado na mão direita, perseguindo a professora auxiliar. Após isso, a criança arremessa o jornal contra a professora.

Análise: A criança, apesar de estar correndo atrás da professora, no momento em que vai arremessar o objeto dá um passo com o pé oposto a mão que vai arremessar (passo contralateral), faz uma rotação de quadril, em seguida traz o ombro para trás, apresentando o movimento do braço de baixo para cima e após esse movimento dá um passo com a perna do mesmo lado da mão que segura o objeto e finaliza o arremesso.

A descrição e análise das cenas acima demonstram uma evolução na habilidade fundamental de arremessar da criança em questão ao longo das sessões de Psicomotricidade Relacional, visto que há diferenças na cena descrita entre a primeira sessão de Psicomotricidade Relacional e a última. A cena da sessão 01 demonstra que o movimento analisado não atende os critérios para um arremesso eficiente, evidenciando que a criança ainda está em um estágio muito inicial da fase fundamental na habilidade do arremessar em comparação com a cena da sessão 08 cuja movimentação corporal já apresenta uma execução que atende alguns critérios da performance apontada por Ulrich (2000) como sendo parte de um movimento eficiente do arremesso.

Garcia e Garcia (2002), em um estudo longitudinal com crianças, perceberam que o desenvolvimento da habilidade fundamental de arremessar é variável, não se apresenta de forma linear e é manipulado pela variação dos contextos ambientais. 
Sendo assim, a competência da habilidade fundamental de arremessar da criança é resultante da interação entre indivíduo, tarefa e ambiente. 


\section{CONSIDERAÇÕES FINAIS}

A partir de uma abordagem espontânea do brincar, na qual o indivíduo é estimulado a entrar numa movimentação e vivência corporal através dos jogos simbólicos estimulados através de objetos, percebeu-se que as sessões de Psicomotricidade Relacional contribuíram para uma evolução positiva sobre o perfil das habilidades motoras e controle postural do indivíduo com Transtorno do Espectro Autista avaliado no presente estudo, o que pode ser evidenciado através dos resultados apresentados pelos testes utilizados, dos relatórios das sessões e dos desenhos da criança.

Com isto, dar-se uma resposta ao problema e objetivo do presente estudo, uma vez que este delineou-se na avaliação dos efeitos de sessões de Psicomotricidade Relacional sobre o perfil das habilidades motoras e no controle postural do indivíduo com Transtorno do Espectro Autista.

As respostas das avaliações contribuíram para termos uma compreensão melhor do comportamento das habilidades motoras e do controle postural, bem como uma visão geral sobre o desenvolvimento motor da criança estudada, antes e após as sessões desenvolvidas e os efeitos positivos que esta proporcionou ao praticante. No processo de intervenção das sessões de Psicomotricidade Relacional, a qual teve como base o brincar, o movimento corporal e a relação com o outro, foi estabelecida uma relação de proximidade com a criança e seus pares, que foi essencial para os resultados encontrados.

Os efeitos nos níveis do perfil das habilidades motoras e no controle postural da criança, demonstrados através de uma evolução nas respostas das avaliações da EDM e na Posturografia, foram positivos. Mas, devemos salientar que a criança do presente estudo é assistida pelo CAPSi e além de participar da oficina de Psicomotricidade Relacional, também recebe assistência multiprofissional com psicólogos, psiquiatras e fonoaudiólogo, bem como está matriculado na escola (CMEI). E isto nos permite levantar algumas observações para futuras investigações, tal como, buscar formas de controle e avaliação para as demais atividades da criança, e perceber quais possíveis influências que estas podem causar.

Apesar de o estudo indicar uma evolução, a criança ainda se encontra com escores motores baixos mediante os parâmetros de desenvolvimento compatível com 
sua idade cronológica. Sendo assim, recomenda-se que as sessões de Psicomotricidade Relacional continuem a ser frequentadas, de modo a dar continuidade no desenvolvimento das habilidades motoras e no refinamento dos mecanismos do controle postural.

Apesar do Transtorno do Espectro Autista ter características peculiares e bem marcadas e cada indivíduo se comportar de maneira diferente, sugere-se o estímulo aos estudos com delineamento que se possam controlar variáveis intervenientes, os quais possam observar respostas a contemplar uma possível generalização quanto aos efeitos da intervenção sobre os déficits do autismo. 


\section{REFERÊNCIAS}

ALMEIDA, C. S.; VALENTINI, N. C. Contexto dos berçários e um programa de intervenção no desenvolvimento de bebés. Motricidade, v. 9, n. 4, p. 22-32, dez. 2013.

ALMEIDA, D. D. Efeitos da atividade física adaptada no perfil psicomotor de uma criança com espetro do autismo. 2014. Tese de Doutorado.

ALVES, F. Psicomotricidade: corpo, ação e emoção. 38ª ed. Rio de Janeiro: Wak Editora, 2007.

ANDRADE, M. P. Autismo e integração sensorial-a intervenção psicomotora como um instrumento facilitador no atendimento de crianças e adolescentes autistas. 2012. Dissertação de mestrado.

ASPERGER, H. Die "Autistischen Psychopathen" in kindesalter. Archiv fur Psychiatrie und Nervenkrankheiten. V. 110, p. 76-136, 1944.

ASSIS, L. C. et al. Game and protagonism of the child in early education. Revista Portuguesa de Educação, Braga, v. 28, n. 1, p. 95-116, jun. 2015.

ASSOCIAÇÃO DE PSIQUIATRIA AMERICANA. Manual diagnóstico e estatístico de transtornos mentais: DSM-5. 5a ed. Porto Alegre: Artmed, 2014.

BARELA, A. M. F.; DUARTE, M. Utilização da plataforma de força para aquisição de dados cinéticos durante a marcha humana. Brazilian Journal of Motor Behavior, v. 6, n. 1, 2011.

BHAT, A. N.; LANDA, R. J.; GALLOWAY, J. C. C. Current perspectives on motor functioning in infants, children, and adults with autism spectrum disorders. Physical Therapy, v. 91, n. 7, p. 1116-1129, 2011.

BOSA, C. A.; CALLIAS, M. Autismo: breve revisão de diferentes abordagens.

Psicologia: reflexão e crítica. Porto Alegre. v. 13, n. 1, p. 167-177, 2000.

BRASIL - Lei 12.764/2012. Brasília: Presidência da República, 2012a.

BRASIL. Ministério da Saúde. Portaria GM/MS no 3.088/11. Brasília, 2011.

BRASIL. Ministério da Saúde. Saúde Mental no SUS: Os Centros de Atenção Psicossocial. Brasília, 2004.

BRASIL. Ministério da Saúde. Centros de Atenção Psicossocial e Unidades de Acolhimento como lugares da atenção psicossocial nos territórios: orientações para elaboração de projetos de construção, reforma e ampliação de CAPS e de UA / Ministério da Saúde, Secretaria de Atenção à Saúde, Departamento de Atenção Especializada e Temática. - Brasília, 2015. 
BRUNIERA, J. R. Z. Análise comparativa do equilíbrio postural pela posturografia em pacientes com vertigem isolada ou associada com perda auditiva. Audiology Communication Research. v. 20, n. 4, p. 321-6, 2015.

CARREIRO, L. R. R. et al. Habilidades cognitivas ao longo do desenvolvimento: contribuições para o estudo da atenção concentrada. Psicologia teórico e prática, São Paulo, v. 17, n. 2, p. 153-170, 2015.

CALHOUN, M.; LONGWORTH, M.; CHESTER, V. L. Gait patterns in children with autismo. Clinical Biomechanics, v. 26, p. 200-206, 2011. Disponível em: <www.elsevier.com/locate/clinbiomech>. Acesso em: 17 junho 2015.

CHANG, C.; et al. Visual tasks and postural sway in children with and without autismo spectrum disorders. Research in Developmental Disabilities, v. 31, p.1536-1542, 2010.

CHELDAVI, $\mathrm{H}$. et al. The effects of balance training intervention on postural control of children with autism spectrum disorder: Role of sensory information. Research in Autism Spectrum Disorders, v. 8, n. 1, p. 8-14, 2014.

COELHO, A. P. M. A. Perfil psicomotor em crianças com e sem autismo: um estudo comparativo. 2011. Tese de Doutorado.

CUNHA, E. Autismo e inclusão: psicopedagogia e práticas educativas na escola e na família. Rio de Janeiro: Wak, 2009.

DANION, F.; DUARTE, M.; GROSJEAN, M. Fitts' law in human standing: the effect of scaling. Neuroscience Letters, v. 277, n. 2, p. 131-133, 1999.

DASCAL, J. B. Controle postural de idosos: efeito da perturbação visual com o uso do sistema âncora. 2009. Tese de Doutorado.

DE FREITAS, P. B. et al. Effects of joint immobilization on standing balance. Human movement science, v. 28, n. 4, p. 515-528, 2009.

D'HONDT, E. et al. Postural balance under normal and altered sensory conditions in normal-weight and overweight children. Clinical biomechanics, v. 26, n. 1, p. 84-89, 2011.

DORNELES, L. R.; BENETTI, L. B. A psicomotricidade como ferramenta da aprendizagem. Revista Monografias Ambientais, v. 8, n. 8, p. 1775-1786, 2012.

DOYLE, C. A.; MCDOUGLE, C. J. Pharmacologic treatments for the behavioral symptoms associated with autism spectrum disorders across the lifespan. Dialogues in Clinical Neuroscience, v. 14, p. 263-279, 2012.

DUARTE, M.; FREITAS, S. M. S. F. Revisão sobre posturografia baseada em plataforma de força para avaliação do equilíbrio. Revista brasileira de fisioterapia, São Carlos, v. 14, n. 3, p. 183-192, 2010. 
DUARTE, M.; ZATSIORSKY, V. M. On the fractal properties of natural human standing. Neuroscience letters, v. 283, n. 3, p. 173-176, 2000.

ENOKA, R. M. Bases neuromecânicas da cinesiologia. $2^{a}$ ed. São Paulo, Manole, 2000.

FALKENBACH, A. P.; DIESEL, D.; OLIVEIRA, L.C; O jogo da criança autista nas sessões de Psicomotricidade Relacional. Rev. Bras. Cienc. Esporte, Campinas, v. 31, n. 2, p. 203-214, jan 2010.

FERNANDES, F. et al. O corpo no autismo. Psic: revista da Vetor Editora, v. 9, n. 1, p. 109-114, 2008.

FERREIRA, I. M. D. M. Uma criança com perturbação do espectro do autismo: um estudo de caso. 2011. Tese de Doutorado. Escola Superior de EducaçãoInstituto Politécnico de Castelo Branco.

FONSECA, V. Manual de observação psicomotora: significação psiconeurológica dos fatores psicomotores. 2ª ed. Lisboa. Ed Âncora. 2007.

FONSECA, V. Psicomotricidade: uma visão pessoal. Construção psicopedagógica, v. 18, n. 17, p. 42-52, 2010.

FORTIN, M. F.; SALGUEIRO, N. O processo de investigação: da concepção à realização. 1999.

FOURNIER, K. A. et al. Decreased static and dynamic postural control in children with autism spectrum disorders. Gait \& Posture, v. 32, p. 6-9, 2010.

FRANCO, B. S. A conquista da autonomia por meio do jogo. Textura-Ulbra, v. 2, n. 3, 2000.

GALLAHUE, D. L.; OZMUN, J. C.; GOODWAY, J. D. Compreendendo o desenvolvimento motor. $7^{\underline{a}}$ ed. Porto Alegre: Artmed, 2013.

Garcia, C.; Garcia, L. Examining developmental changes in throwing. In: Clark, J.; Humphrey, J. (Eds.) Motor Development: Research and Reviews. v.2. Reston: NASPE Publications. pp.62-95. 2002.

GLASENAPP, A. L. C. A psicomotricidade relacional como instrumento de intervenção e prevenção para a criança. 2012. Monografia.

GRIBBLE, P. A.; HERTEL, J. Effect of hip and ankle muscle fatigue on unipedal postural control. Journal of Electromyography and Kinesiology, v. 14, n. 6, p. 641-646, 2004.

JESTE, S. S. The neurology of autism spectrum disorders. Current opinion in neurology, v. 24, n. 2, p. 132, 2011. 
KANNER, L. Autistic disturbances of affective contact. Nervous Child, New York, v. 2, p. 217-250, 1943. Disponível em:

<http://neurodiversity.com/library_kanner_1943.pdf>. Acesso em: 16 jun. 2014.

KEGEL, A.; et al. Construct Validity of the Assessment of Balance in Children Who Are Developing Typically and in Children With Hearing Impairments. Physical Therapy, v. 90, n. 12, p. 1783-1794, 2010.

KELLY, Valerie E. et al. Association of cognitive domains with postural instability/gait disturbance in Parkinson's disease. Parkinsonism \& related disorders, v. 21, n. 7, p. 692-697, 2015.

KISHIMOTO, T. M. Brinquedos e brincadeiras na educação infantil. Anais do I Seminário Nacional: Currículo Em Movimento, Belo Horizonte, p.1-20, 2010.

KLIN, A. Autismo e síndrome de Asperger: uma visão geral. Revista Brasileira de Psiquiatria. V. 28, supl 1, p. s3 - s11. 2006.

KOHEN-RAZ, R.; VOLKMAN, F. R.; COHEN, D. J. Postural control in children with autism. Journal of Autism and Developmental Disorders, V. 22, n. 3, p. 419, 1992.

LAI, M. C.; LOMBARDO, M. V.; BARON-COHEN, S. Autism. Lancet, v. 383, p. 896910, 2014.

LANDA, R.; MAYER, E. G. Development in infants with autism spectrum disorders: a prospective study. Journal of Child Psychology and Psychiatry, v. 47, n. 6, p. 629-638, 2006.

LAPIERRE, A. Da psicomotricidade Relacional à análise corporal da relação. 1a ed., Curitiba: Ed. UFPR, 2010.

LAPIERRE, A. El juego: expresión primera del inconsciente. Revista iberoamericana de psicomotricidad y técnicas corporales, n. 31, p. 37-42, 2008.

LAPIERRE, A.; AUCOUTOURIER, B. Fantasmas Corporais e Prática

Psicomotora. São Paulo: Ed. Manole, 1984.

LAPIERRE, A.; AUCOUTURIER, B. A Simbologia do movimento:

Psicomotricidade e educação. Curitiba: Filosofart, 2004.

LAPIERRE, A.; LAPIERRE, A. $\mathbf{O}$ adulto diante da criança de $\mathbf{0}$ a $\mathbf{3}$ anos:

psicomotricidade relacional e formação da personalidade. Tradução de Maria

Ermantina GG. Pereira. 2ª ed. Curitiba: Ed. da UFPR, 2002.

LARSON, J. C. G. et al. Acquisition of internal models of motor tasks in children with autism. Brain, v. 131, n. 11, p. 2894-2903, 2008.

LE BOULCH, J. A. Educação Psicomotora: Psicocinética na Idade Escolar. Tradução: WOLF, Jeni. Porto Alegre: Artes Médicas, 1987. 
LE BOULCH, J. O desenvolvimento Psicomotor: do nascimento até os 6 anos. 7.ed. Porto Alegre: Artes Médicas, 1992.

LIMA, C. B. Perturbações do Espectro do Autismo: Manual Prático de Intervenção, 2 ${ }^{\mathrm{a}}$ ed. Lisboa: Lidel, 2012.

LIMA, Cláudia Bandeira de et al. O Impacto do Programa Integrado Para o Autismo (PIPA). Revista de Psicologia da Criança e do Adolescente, Lisboa, v. 5, n. 1, p.231-244, maio 2014.

LIU, T.; BRESLIN, C. M. Fine and gross motor performance of the MABC-2 by children with autism spectrum disorder and typically developing children. Research in autism spectrum disorders, v. 7, p. 1244-1249, 2013.

LOFTHOUSE, N. et al. A review of complementary and alternative treatments for autism spectrum disorders. Autism research and treatment, v. 2012, 2012.

LOPES, L. et al. Associações entre atividade física, habilidades e coordenação motora em crianças portuguesas. Revista Brasileira de Cineantropometria \& Desempenho Humano, v. 13, p. 15-21, 2011

LOTH, Eduardo Alexandre et al. Avaliação do controle postural em adultos jovens através da posturografia dinâmica Foam-laser e plataforma de força. Revista brasileira de medicina e esporte, v. 17, n. 3, p. 171-174, 2011.

MACHE, M. A.; TODD, T. A. Gross motor skills are related to postural stability and age in children with autism spectrum disorder. Research in Autism Spectrum Disorders, v. 23, p. 179-187, 2016.

MAGILL, Richard A. Aprendizagem motora: conceitos e aplicações. São Paulo: Edgard Blücher, 2000.

MANSUR, S. S.; MARCON, A. J. Perfil motor de crianças e adolescentes com deficiência mental moderada. Revista Brasileira de Crescimento e Desenvolvimento Humano. v. 16, n. 3, p. 09-15, 2006.

MATSON, J. L., et al. Motor skill abilities in toddlers with autistic disorder, pervasive developmental disorder-not other-wise specified, and atypical development.

Research in Autism Spectrum Disorders, v. 4, p. 444-449, 2010.

MEMARI, A. H. et al. Postural sway patterns in children with autism spectrum disorder compared with typically developing children. Research in autism spectrum disorders, v. 7, n. 2, p. 325-332, 2013.

MILTEER, Regina M. et al. The importance of play in promoting healthy child development and maintaining strong parent-child bond: Focus on children in poverty. Pediatrics, v. 129, n. 1, p. e204-e213, 2012. 
MINSHEW, N. J. et al. Underdevelopment of the postural control system in autismo. Neurology, v. 63, p. $2056-2061,2004$.

MOLLOY, C. A.; DIETRICH, K. N.; BHATTACHARYA, A. Postural Stability in Children with Autism Spectrum Disorder. Journal of Autism and Developmental Disorders, v. 33, n. 6, 2003.

MULAS, Fernando et al. Modelos de intervención en niños con autismo. Revista de Neurologia, v. 50, n. 3, p. 77-84, 2010.

NASHNER, L. M. Analysis of stance posture in humans. In: Motor coordination. Springer US, p. 527-565, 1981.

NATIONAL INSTITUTE OF MENTAL HEALTH: NIMH. A Parent's Guide to Autism Spectrum Disorder. 2011.

NUNES, D. R. P.; RODRIGUES ARAÚJO, E. Autismo: a educação infantil como cenário de intervenção. Education Policy Analysis Archives/Arquivos Analíticos de Políticas Educativas. v. 22, n. 84, 2014.

OKUDA, Paola Matiko; MISQUIATTI, Andrea Regina Nunes; CAPELLINI, Simone Aparecida. Caracterização do perfil motor de escolares com transtorno autístico. Revista Educação Especia, Santa Maria, v. 23, n. 38, p.443-454, set. 2010.

OLIVEIRA, G. C. Psicomotricidade: educação e reeducação enfoque psicopedagógico. 14. ed. Rio de Janeiro: Editora Vozes, 2009.

ONU. Rejeitar pessoas com autismo é 'um desperdício de potencial humano', destacam representantes da ONU. 2016. Disponível em:

$<$ https://nacoesunidas.org/rejeitar-pessoas-com-autismo-e-um-desperdicio-depotencial-humano-destacam-representantes-da-onu/>. Acesso em: 12 jul. 2016.

ORGANIZAÇÃO MUNDIAL DA SAÚDE. Classificação Estatística Internacional de Doenças e Problemas Relacionados à Saúde - CID-10. Disponível em: <www.datasus.gov.br/cid10/v2008/cid10.htm> Acesso em: 28 jun. 2014.

PIAGET, J. A formação do símbolo na criança: imitação, jogo e sonho, imagem e Representação. 2. ed. Rio de Janeiro: Zahar, Brasília: INL, 1975.

POLLOCK, A. S. et al. What is balance?.Clinical rehabilitation, v. 14, n. 4, p.

PRESTES, D. B. et al. Avaliação e intervenção motora com uma criança autista. Efdeportes.com, Revista Digital, Buenos Aires, ano 14, n. 138, nov. 2009.

RIBEIRO, G. F.; BONONE, C. G. G. Ginástica artística feminina: as habilidades motoras de atletas residentes em casas e apartamentos na cidade de Caxias do Sul - RS. Do Corpo: Ciências e Artes. Caxias do Sul, v. 4, n. 1, 2014.

ROSA NETO, F. Manual de avaliação motora. DIOESC, 2014. 
ROSA NETO, Francisco et al. Efeitos da intervenção motora em uma criança com Transtorno do Espectro do Autismo. Temas Sobre Desenvolvimento, São Paulo, v. 19, n. 105, p.110-114, abr. 2013.

RUDIO, F. V. Introdução ao projeto de pesquisa científica. Vozes, 2010.

SANTOS, S. DANTAS, L. OLIVEIRA, J. A. Desenvolvimento motor de crianças, de idosos e de pessoas com transtornos da coordenação. Revista Paulista de Educação Física, v. 18, p. 33-44, 2004.

SHUMWAY-COOL, A.; WOOLACOTT, M. H. Controle Motor: Teoria e aplicações práticas. 3. ed. Barueri, SP: Manole, 2010.

SILVA, M.G. Análise do controle postural e muscular do lançamento de precisão no futebol em condições de dupla-tarefa e fadiga neuromuscular. 2016. 148 f. Tese (Doutorado em Engenharia Mecânica) - Faculdade de Engenharia do Campus de Guaratinguetá, 2016.

SOARES, C. S. F. O espectro do autismo. 2009. Monografia. Escola Superior de Educação Paula Francinetti. Porto.

SOUSA, A. M. M. Equilíbrio corporal e controle postural entre crianças com desenvolvimento típico e crianças com deficiência auditiva usuária e nãousuárias de implante coclear. [tese] Universidade de Brasília, 2012.

SOUZA, J. G. V. O Lúdico na educação infantil: possibilidades do aprender brincando em contextos de formação. Marcas Educativas, v. 1, n. 1, 2011.

STELZER, F. G. Uma pequena história do autismo. Cadernos pandorgas de autismo, v. 1, São Leopoldo - RS: Editora Oikos, 2010.

TAMANAHA, A. C.; PERISSINOTO, J.; CHIARI, B. M. Uma breve revisão histórica sobre a construção dos conceitos do Autismo Infantil e da síndrome de Asperger. Revista da Sociedade Brasileira de Fonoaudiologia, v.13, n, 3, p. 296 - 299, 2008.

TEIXEIRA, C.. EQUILIBRIO E CONTROLE POSTURAL. Brazilian Journal of Biomechanics. Revista Brasileira de Biomecânica, América do Norte, 2013.

TORQUATO, J. A. et al. A aquisição da motricidade em crianças portadoras de Síndrome de Down que realizam fisioterapia ou praticam equoterapia. Fisioterapia e Movimento, v. 26, n. 3, p. 515-24, 2013.

TRAVERS, B. G., et al. Motor Difficulties in Autism Spectrum Disorder: Linking Symptom Severity and Postural Stability. J Autism Dev Disord, n. 43, p.1568-1583, 2013.

TUSTIN, F. Autistic states in children. Routledge, 2013.

ULRICH, Dale A. Test of gross motor development-2. Austin: Prod-Ed, 2000. 
VIEIRA, J. L.; BATISTA, M. I. B.; LAPIERRE, A. Psicomotricidade Relacional: A teoria de uma prática. 2ª ed., Curitiba - PR: Editora Filosofart, 2005.

VYGOTSKY, L. S. A formação social da mente: o desenvolvimento dos processos psicológicos superiores. São Paulo: Martins Fortes, 2007.

WESTCOTT, S. L.; LOWES, L. P.; RICHARDSON, P. K. Evaluation of postural stability in children: current theories and assessment tools. Physical therapy, v. 77, n. 6, p. 629-645, 1997.

WORLD HEALTH ORGANIZATION. Meeting Report: autism spectrum disorders and other developmental disorders: from raising awareness to building capacity. WHO press. Suiça, 2013.

YIN, R. K. Estudo de Caso: planejamento e métodos, tradução Ana Thorell, revisão técnica Cláudio Damacena. 2010. 


\title{
APÊNDICES
}

\author{
APÊNDICE A - DECLARAÇÃO DE CIÊNCIA INSTITUCIONAL
}

\section{UNIVERSIDADE FEDERAL DO RIO GRANDE DO NORTE CENTRO DE CIÊNCIAS DA SAÚDE DEPARTAMENTO DE EDUCAÇÃO FÍSICA PROGRAMA DE PÓS-GRADUAÇÃO STRICTO-SENSU EM EDUCAÇÃO FÍSICA}

Projeto de Pesquisa: Efeitos de sessões de Psicomotricidade Relacional sobre o perfil das habilidades motoras e controle postural em indivíduo com Transtorno do Espectro Autista.

Pesquisadora Responsável: Ana Charline Dantas Ferreira.

\section{DECLARAÇÃO DE CIÊNCIA INSTITUCIONAL}

Eu, de livre e espontânea vontade autorizo a participação na pesquisa "Efeitos de sessões de Psicomotricidade Relacional sobre o perfil das habilidades motoras e controle postural em indivíduo com Transtorno do Espectro Autista" dos (as) alunos (as) da sob minha responsabilidade.

Informo que, quando julgar necessário e sem qualquer prejuízo, poderei cancelar o presente termo de consentimento livre e esclarecido.

Autorizo os (as) alunos (as) a realizarem os seguintes procedimentos de avaliação do equilíbrio corporal:

- Mensuração do equilíbrio em plataforma de força, que analisam o comportamento do Centro de Pressão nas seguintes condições:

○ Com visão;

- Sem visão.

Fui informado de que estes procedimentos de avaliação não acarretarão nenhum prejuízo ou dano para o (a) aluno (a), e que contribuirão para fornecer parâmetros confiáveis para as equipes multiprofissionais melhor avaliar, planejar e acompanhar as intervenções terapêuticas e pedagógicas juntos aos indivíduos com TEA.

Estou ciente de não haverá risco ao indivíduo, pois os procedimentos não causam dor ou esforço físico e não são de cunho invasivo.

Certifico de que tive a oportunidade de ler e entender o conteúdo das palavras contidas no termo, sobre o qual me foram dadas explicações.

Natal, RN de de

Responsável pela Instituição

Pesquisador responsável: Ana Charline Dantas Ferreira / Tel: 98809-6392. 


\section{APÊNDICE B - TERMO DE CONCENTIMENTO LIVRE E ESCLARECIDO}

\section{UNIVERSIDADE FEDERAL DO RIO GRANDE DO NORTE - UFRN CENTRO DE CIÊNCIAS DA SAÚDE \\ DEPARTAMENTO DE EDUCAÇÃO FÍSICA}

Projeto de Pesquisa: Sessões de Psicomotricidade Relacional sobre o Controle Postural e Perfil Motor em crianças com Transtorno do Espectro Autista - TEA

Pesquisadora Responsável: Ana Charline Dantas Ferreira

TERMO DE CONSENTIMENTO LIVRE E ESCLARECIDO

$\mathrm{Eu}$, , RG:

CPF: responsável legal do (a) aluno (a) declaro ter sido

informado, após ler ou ouvir o presente documento e compreendido o seu significado que informa o seguinte:

1- Estou autorizando de minha livre vontade, que meu tutelado seja submetido (a) a participação em projeto de pesquisa e avaliação para determinação do Perfil Motor e medidas para avaliação do Controle Postural, o que não Ihe causará mal algum;

2- O presente trabalho tem como objetivo verificar o efeito de sessões de Psicomotricidade Relacional sobre o Perfil Motor e Controle Postural e fornecer parâmetros confiáveis para as equipes multiprofissionais melhor avaliar, planejar e acompanhar as intervenções terapêuticas e pedagógicas dos alunos;

3- Para coleta dos dados serão utilizados o protocolo da Escala de Desenvolvimento Motor - EDM - que consiste numa bateria de testes para avaliação da Motricidade fina, Motricidade Global, Equilíbrio, Esquema Corporal e Organização espacial; e plataforma de força para analisar o Controle Postural através do Centro de Pressão, onde o indivíduo deverá ficar sobre uma plataforma nas seguintes posições: Olhos Abertos, Posição Normal dos Pés; Olhos Fechados Posição Normal dos Pés.

4- Fui esclarecido (a) de que a participação é voluntária (sem qualquer forma de pagamento), estando garantido o sigilo dos dados envolvidos na pesquisa. As informações provenientes deste trabalho (fotografias, vídeos, resultados dos testes) serão utilizadas com fins de divulgação científica.

Natal/RN, de de

Pai ou responsável Testemunha

Pesquisador responsável

Pesquisador responsável: Ana Charline Dantas Ferreira / Telefone: (84) 98809-6392 / 99970-1859 
APÊNDICE C - PLANOS DE AULA - PSICOMOTRICIDADE RELACIONAL

\section{PLANO DE SESSÃO 01 - BOLA}

Local: CAPS I Natal (infantil).

Tema: Pulsão de vida dos sujeitos e as primeiras inibições.

Horário: 1 hora de duração (Entre 10hs e 11hs).

Objetivo: Contribuir para o desenvolvimento da consciência transitiva crítica e da autonomia dos beneficiários do CAPS I de Natal, que participam do Projeto de Extensão em Psicomotricidade Relacional, especialmente no que se refere a fase de inibição predominante na primeira sessão de jogo simbólico.

Justificativa: Considerando a necessidade de desenvolvimento da consciência e da autonomia dos participantes, bem como que na primeira sessão é prevalente a necessidade de percepção, tanto das pulsões de vida de cada sujeito, quanto das inibições mais frequentes dos participantes diante do jogo simbólico, faz-se necessária essa intervenção.

Espaço físico: Auditório do CAPSI de Natal (infantil).

Materiais: 09 bolas nogan, 06 bolas suíças. Para além dos recursos materiais diretos da sessão, ainda se utilizará, 01 filmadora digital e analógica, 01 máquina fotográfica digital, 20 folhas de anotação para relatório espontâneo, 2 canetas esferográficas, 20 gizes de cera.

Metodologia: Será utilizado o método de jogo (em especial o simbólico) na parte principal da sessão e, também, o debate em formação circular (aula dialógica) no ritual de entrada e saída da sessão.

\section{Conteúdo programático:}

1‥ Parte: Ritual de entrada (10 minutos).

2a. Parte: Principal (40 minutos).

Atividade 3 - Ritual de saída (10 minutos);

Avaliação: Desenhos feitos pelos participantes e relatórios espontâneo e reflexivo dos psicomotricistas.

\section{PLANO DE SESSÃO 02 - BAMBOLE}

Local: CAPSI Natal (infantil). 
Tema: A agressividade pura como pulsão de vida dos sujeitos e o rompimento das primeiras inibições durante o estímulo da organização espacial

Horário: 1 hora de duração (Entre 10hs e 11hs).

Objetivo: Contribuir para o desenvolvimento da consciência transitiva crítica e da autonomia dos beneficiários do CAPSI de Natal, que participam do Projeto de Extensão em Psicomotricidade Relacional, especialmente no que se refere a vivência da agressividade pura como manifestação da pulsão de vida e a tentativa de diminuir o comportamento inibido de algumas crianças na primeira sessão de jogo simbólico. Também, estimular situações em que a organização espacial será trabalhada em virtude da característica do material bambolê.

Justificativa: Considerando a necessidade de desenvolvimento da consciência e da autonomia dos participantes, bem como que há resquícios de inibição da primeira sessão, da necessidade de provocar a manifestação da agressividade pura como forma de linguagem corporal e, também, da relevância de explorar o material bambolê como meio para o desenvolvimento da organização espacial, faz-se necessária essa intervenção.

Espaço físico: Auditório do CAPSI de Natal (infantil).

Materiais: 15 bambolês. Para além dos recursos materiais diretos da sessão, 01 filmadora digital e analógica, 01 máquina fotográfica digital, 20 folhas de anotação para relatório espontâneo, 20 gizes de cera.

Metodologia: Será utilizado o método de jogo (em especial o simbólico) na parte principal da sessão e, também, o debate em formação circular (aula dialógica) no ritual de entrada e saída da sessão. Antes de ritual de saída, será feito um relaxamento.

\section{Conteúdo programático:}

1‥ Parte: Ritual de entrada (10 minutos).

2. Parte: Principal (40 minutos).

Atividade 3 - Ritual de saída (10 minutos);

Avaliação: Desenhos feitos pelos participantes e relatórios espontâneo e reflexivo dos psicomotricistas.

\section{PLANO DE SESSÃO 03 - CORDA}

Local: CAPSI Natal (infantil). 
Tema: A agressividade pura como pulsão de vida dos sujeitos e a agressividade simbólica como alternativa comunicacional durante a continuação do estímulo da organização espacial.

Horário: 1 hora de duração (Entre 10hs e 11hs).

Objetivo: Contribuir para o desenvolvimento da consciência transitiva crítica e da autonomia dos beneficiários do CAPSI de Natal, que participam do Projeto de Extensão em Psicomotricidade Relacional, especialmente no que se refere a vivência da agressividade pura, como manifestação da pulsão de vida e, também, da agressividade simbólica, como forma de alternativa de comunicação entre o adulto e a criança, por intermédio de situações que estimulem a organização espacial, em virtude da característica do material corda.

Justificativa: Considerando a necessidade de desenvolvimento da consciência e da autonomia dos participantes, bem como que há resquícios da agressividade pura da segunda sessão, da necessidade de provocar a manifestação da agressividade pura e simbólica como formas de linguagem corporal e, também, da relevância de explorar o material corda como meio para o desenvolvimento da organização espacial, faz-se necessária essa intervenção.

Espaço físico: Auditório do CAPSI de Natal (infantil).

Materiais: 15. Para além dos recursos materiais diretos da sessão, 01 filmadora digital e analógica, 01 máquina fotográfica digital, 20 folhas de anotação para relatório espontâneo, 20 gizes de cera.

Metodologia: Será utilizado o método de jogo (em especial o simbólico) na parte principal da sessão e, também, o debate em formação circular (aula dialógica) no ritual de entrada e saída da sessão. Antes de ritual de saída, será feito um relaxamento.

\section{Conteúdo programático:}

1‥ Parte: Ritual de entrada (10 minutos).

2‥ Parte: Principal (40 minutos).

Atividade 3 - Ritual de saída (10 minutos);

Avaliação: Desenhos feitos pelos participantes e relatórios espontâneo e reflexivo dos psicomotricistas.

\section{PLANO DE SESSÃO 04 - BASTÃO}


Local: CAPSI Natal (infantil).

Tema: As agressividades pura e simbólica como alternativas comunicacionais e o processo de dominação do adulto pelas crianças, associado a organização espaço temporal.

Horário: 1 hora de duração (Entre 10hs e 11hs).

Objetivo: Contribuir para o desenvolvimento da consciência transitiva crítica e da autonomia dos beneficiários do CAPSI de Natal, que participam do Projeto de Extensão em Psicomotricidade Relacional, especialmente no que se refere a vivência das agressividades pura e simbólica, como formas de alternativas comunicacionais entre o adulto e a criança, por intermédio de situações que estimulem a organização espacial e temporal, em virtude da característica do material bastão.

Justificativa: Considerando a necessidade de desenvolvimento da consciência e da autonomia dos participantes, bem como que há resquícios da inibição ainda e, também, da agressividade pura e simbólica da terceira sessão e, também, da relevância de explorar o material bastão como meio para o desenvolvimento da organização espacial e temporal, faz-se necessária essa intervenção.

Espaço físico: Auditório do CAPSI de Natal (infantil).

Materiais: 15. Para além dos recursos materiais diretos da sessão, 01 filmadora digital e analógica, 01 máquina fotográfica digital, 20 folhas de anotação para relatório espontâneo, 20 gizes de cera.

Metodologia: Será utilizado o método de jogo (em especial o simbólico) na parte principal da sessão e, também, o debate em formação circular (aula dialógica) no ritual de entrada e saída da sessão. Antes de ritual de saída, será feito um relaxamento.

\section{Conteúdo programático:}

1‥ Parte: Ritual de entrada (10 minutos).

2a. Parte: Principal (40 minutos).

Atividade 3 - Ritual de saída (10 minutos);

Avaliação: Desenhos feitos pelos participantes e relatórios espontâneo e reflexivo dos psicomotricistas.

\section{PLANO DE SESSÃO 05 - CAIXA}

Local: CAPSI Natal (infantil). 
Tema: A agressividade simbólica como alternativas comunicacional, o processo de dominação e domesticação do adulto pelas crianças, o jogo simbólico e a organização espacial.

Horário: 1 hora de duração (Entre 10hs e 11hs).

Objetivo: Contribuir para o desenvolvimento da consciência transitiva crítica e da autonomia dos beneficiários do CAPSI de Natal, que participam do Projeto de Extensão em Psicomotricidade Relacional, especialmente no que se refere a vivência das agressividades simbólica, como alternativa comunicacional entre o adulto e a criança e o jogo simbólico, por intermédio de situações que estimulem a organização espacial, em virtude da característica do material caixa.

Justificativa: Considerando a necessidade de desenvolvimento da consciência e da autonomia dos participantes, bem como que ainda não houve um processo de domesticação amplamente vivido, também, da agressividade simbólica até a quarta sessão e, também, da relevância de explorar o material caixa como meio para o desenvolvimento da organização espacial, faz-se necessária essa intervenção.

Espaço físico: Auditório do CAPSI de Natal (infantil).

Materiais: 16 caixas de papelão. Para além dos recursos materiais diretos da sessão, 01 filmadora digital e analógica, 01 máquina fotográfica digital, 20 folhas de anotação para relatório espontâneo, 20 gizes de cera.

Metodologia: Será utilizado o método de jogo (em especial o simbólico) na parte principal da sessão e, também, o debate em formação circular (aula dialógica) no ritual de entrada e saída da sessão. Antes de ritual de saída, será feito um relaxamento.

\section{Conteúdo programático:}

1‥ Parte: Ritual de entrada (10 minutos).

2. Parte: Principal (40 minutos).

Atividade 3 - Ritual de saída (10 minutos);

Avaliação: Desenhos feitos pelos participantes e relatórios espontâneo e reflexivo dos psicomotricistas.

\section{PLANO DE SESSÃO 06 - TECIDO}

Local: CAPSI Natal (infantil). 
Tema: O jogo simbólico como alternativa comunicacional e a estimulação do equilíbrio estático e dinâmico e a organização espacial e temporal.

Horário: 1 hora de duração (Entre 10hs e 11hs).

Objetivo: Contribuir para o desenvolvimento da consciência transitiva crítica e da autonomia dos beneficiários do CAPSI de Natal, que participam do Projeto de Extensão em Psicomotricidade Relacional, especialmente no que se refere a vivência do jogo simbólico, como alternativa comunicacional entre o adulto e a criança, por intermédio de situações que estimulem o equilíbrio corporal e a organização espacial e temporal em virtude da característica do material tecido.

Justificativa: Considerando a necessidade de desenvolvimento da consciência e da autonomia dos participantes, bem como que ainda não houve um processo de domesticação amplamente vivido, também, da agressividade simbólica até a quarta sessão e, também, da relevância de explorar o material tecido como meio para o desenvolvimento do equilíbrio e da organização espacial e temporal, faz-se necessária essa intervenção.

Espaço físico: Auditório do CAPSI de Natal (infantil).

Materiais: 15 tecidos de tamanhos, formatos, cores e texturas diferentes. Para além dos recursos materiais diretos da sessão, 01 filmadora digital e analógica, 01 máquina fotográfica digital, 20 folhas de anotação para relatório espontâneo, 20 gizes de cera. Metodologia: Será utilizado o método de jogo (em especial o simbólico) na parte principal da sessão e, também, o debate em formação circular (aula dialógica) no ritual de entrada e saída da sessão. Antes de ritual de saída, será feito um relaxamento.

Conteúdo programático:

1‥ Parte: Ritual de entrada (10 minutos).

2a. Parte: Principal (40 minutos).

Atividade 3 - Ritual de saída (10 minutos);

Avaliação: Desenhos feitos pelos participantes e relatórios espontâneo e reflexivo dos psicomotricistas.

\section{PLANO DE SESSÃO 07 - JORNAL}

Local: CAPSI Natal (infantil).

Tema: O jogo simbólico como alternativa comunicacional e a estimulação do equilíbrio estático e dinâmico e a organização espacial e temporal. 
Horário: 1 hora de duração (Entre 10hs e 11hs).

Objetivo: Contribuir para o desenvolvimento da consciência transitiva crítica e da autonomia dos beneficiários do CAPSI de Natal, que participam do Projeto de Extensão em Psicomotricidade Relacional, especialmente no que se refere a vivência do jogo simbólico, como alternativa comunicacional entre o adulto e a criança, por intermédio de situações que estimulem o esquema corporal em virtude da característica do material jornal.

Justificativa: Considerando a necessidade de desenvolvimento da consciência e da autonomia dos participantes, bem como a necessidade de explorar o material jornal como meio para o desenvolvimento do esquema corporal, faz-se necessária essa intervenção.

Espaço físico: Auditório do CAPSI de Natal (infantil).

Materiais: 4 Fardos de $5 \mathrm{~kg}$ de jornal. Para além dos recursos materiais diretos da sessão, 01 filmadora digital e analógica, 01 máquina fotográfica digital, 20 folhas de anotação para relatório espontâneo, 20 gizes de cera.

Metodologia: Será utilizado o método de jogo (em especial o simbólico) na parte principal da sessão e, também, o debate em formação circular (aula dialógica) no ritual de entrada e saída da sessão. Antes de ritual de saída, será feito um relaxamento.

\section{Conteúdo programático:}

1‥ Parte: Ritual de entrada (10 minutos).

2a. Parte: Principal (40 minutos).

Atividade 3 - Ritual de saída (10 minutos);

Avaliação: Desenhos feitos pelos participantes e relatórios espontâneo e reflexivo dos psicomotricistas.

\section{PLANO DE SESSÃO 08 - MATERIAL MISTO}

Local: CAPSI Natal (infantil).

Tema: Jogo e autonomia enquanto livre expressão simbólica.

Horário: 1 hora de duração (Entre 10hs e 11hs). 
Objetivo: Contribuir para o desenvolvimento da consciência transitiva crítica e da autonomia dos beneficiários do CAPSI de Natal, que participam do Projeto de Extensão em Psicomotricidade Relacional, especialmente no que se refere a expressão livre e simbólica do jogo com autonomia, em que todas as aptidões motoras poderão ser estimuladas em virtude da diversidade de materiais desta sessão.

Justificativa: Considerando a necessidade de desenvolvimento da consciência e da autonomia dos participantes, bem como da vivência predominante do jogo simbólico com autonomia e, também, da relevância de explorar o conjunto das aptidões motoras por intermédio da mistura dos diferentes materiais já utilizados, faz-se necessária essa intervenção.

Espaço físico: Auditório do CAPSI de Natal (infantil).

Materiais: 2 caixas de papelão, 2 bolas suíças, 2 cordas, 4 tecidos, 2 bambolês, 2 bastões e alguns jornais. Para além dos recursos materiais diretos da sessão, 01 filmadora digital e analógica, 01 máquina fotográfica digital, 20 folhas de anotação para relatório espontâneo, 20 gizes de cera.

Metodologia: Será utilizado o método de jogo (em especial o simbólico) na parte principal da sessão e, também, o debate em formação circular (aula dialógica) no ritual de entrada e saída da sessão. Antes de ritual de saída, será feito um relaxamento.

\section{Conteúdo programático:}

1‥ Parte: Ritual de entrada (10 minutos).

2a. Parte: Principal (40 minutos).

Atividade 3 - Ritual de saída (10 minutos);

Avaliação: Desenhos feitos pelos participantes e relatórios espontâneo e reflexivo dos psicomotricistas. 
ANEXOS

\title{
ANEXO A - APRECIAÇÃO PELO COMITÊ DE ÉTICA EM PESQUISA
}

\author{
UNIVERSIDADE FEDERAL DO \\ RIO GRANDE DO NORTE / \\ UFRN CAMPUS CENTRAL
}

PARECER CONSUBSTANCIADO DO CEP

DADOS DO PROJETO DE PESQUISA

Título da Pesquisa: ESTUDO DE CASO: A PSICOMOTRICIDADE RELACIONAL COMO PRATICA TERAPEUUTICA E PEDAGÓGICA COM CRIANÇA AUTISTA

Pesquisador: Débora Lima de Oliveira

Área Temática:

Versão: 2

CAAE: 45185815.0 .0000 .5537

Instituição Proponente: Pós-Graduação em Educação Física

Patrocinador Principal: Financiamento Próprio

DADOS DO PARECER

Número do Parecer: 1.131 .835

Data da Relatoria: $26 / 06 / 2015$

Apresentação do Projeto:

O projeto de pesquisa tem nível de abrangência de Mestrado, será desenvolvido no Programa de PósGraduação em Educação Fisica, e como coparticipante o centro de atenção psicossocial CAPSi e tem como objetivo; avaliar os benefícios do programa de intervenção em Psicomotricidade Relacional. A amostra será composta por 1 criança autista na faixa etária de 3 a 6 anos. Trata-se de um estudo de caso, de corte qualitativo, utilizará metodologia descritiva. Para coleta de dados, serão utilizados dados do prontuário, com o intuito de verificar o diagnóstico de autismo, que é um critério de inclusão e dados do campo afetivo. Serão utilizados também análise documental. Neste trabalho, os pesquisadores optaram por um estudo de "caso único", por tratar-se de uma instituição com características peculiares, uma instituição que trabalha com indivíduos com algum tipo de comprometimento intelectual, patologias mentais e indivíduos autistas, foco da pesquisa. Mas, especificamente por buscar circunstâncias que podem confirmar ou ampliar a abordagem da Psicomotricidade Relacional. Quanto ao desenvolvimento do estudo de caso, será evidenciado três fases, que são: a exploratória ou definição de focos; estudos da literatura, planejamento das àções, a fase de coleta de dados ou delimitação do estudo; e a fase de análise sistemática dos dados. Para a efetivação desse trabalho de pesquisa, serão seguidos os seguintes passos: 1- A observação, registros, já na perspectiva nova de inclusão de instrumentos como fotografias,

Endereço: Av. Senador Salgado Filho, 3000 Bairro: Lagoa Nova UF: RN Município: NATAL CEP: $59.078-970$ 


\section{UNIVERSIDADE FEDERAL DO RIO GRANDE DO NORTE / UFRN CAMPUS CENTRAL}

Continuação do Parecer: 1.131.83

Necessita Apreciação da CONEP:

Não

Considerações Finais a critério do CEP:

Em conformidade com a Resolução 466/12 do Conselho Nacional de Saúde - CNS e Manual Operacional para Comitês de Ética - CONEP é da responsabilidade do pesquisador responsável:

1. elaborar o Termo de Consentimento Livre e Esclarecido - TCLE em duas vias, rubricadas em todas as suas páginas e assinadas, ao seu término, pelo convidado a participar da pesquisa, ou por seu representante legal, assim como pelo pesquisador responsável, ou pela (s) pessoa (s) por ele delegada(s), devehdo as páginas de assinatura estar na mesma folha (Res. 466/12 - CNS, item IV.5d);

2. desenvolver o projeto conforme o delineado (Res. 466/12 - CNS, item XI.2c);

3. apresentar ao CEP eventuais emendas ou extensões com justificativa (Manual Operacional para Comitês de Ética - CONEP, Brasilia - 2007, p. 41);

4. descontinuar o estudo somente após análise e manifestação, por parte do Sistema CEP/CONEP/CNS/MS que o aprovou, das razões dessa descontinuidade, a não ser em casos de justificada urgência em beneficio de seus participantes (Res. 446/12 - CNS, item III.2u);

5. elaborar e apresentar os relatórios parciais e finais (Res. 446/12 - CNS, item XI.2d);

6. manter os dados da pesquisa em arquivo, fisico ou digital, sob sua guarda e responsabilidade, por um período de 5 anos após o término da pesquisa (Res. 446/12 - CNS, item XI.2f);

7. encaminhar os resultados da pesquisa para publicação, com os devidos créditos aos pesquisadores associados e ao pessoal técnico integrante do projeto (Res. $446 / 12$ - CNS, item XI.2g) e,

8. justificar fundamentadamente, perante o CEP ou a CONEP, interrupção do projeto ou não publicação dos resultados (Res. $446 / 12$ - CNS, item XI.2h).

NATAL, 30 de Junho de 2015

Assinado por:
LÉLIA MARIA GUEDES QUEIROZ
(Coordenador)

Endereço: Av. Senador Salgado Fitho, 3000

Bairro: Lagoa Nova

UF: RN Município: NATA

Telefone: (84)3215-3135

E-mail: cepufm@reitoria.ufm.br 


\section{UNIVERSIDADE FEDERAL DO RIO GRANDE DO NORTE / UFRN CAMPUS CENTRAL}

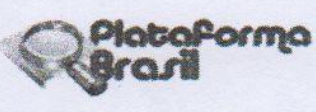

Continuaçāo do Parecer: 1.131.835

videos, DVDs, desenhos, que subsidiarão um novo olhar a avaliação do desenvolvimento das crianças, do trabalho na Unidade CAPS-I, e discussão sobre o referido trabalho com outras pesquisadoras e estudiosas dessa proposta; 2- análise e estudos bibliográficos da literatura acerca da temática definida; 3- análise e discussão da proposta com a equipe de profissionais do CAPS-I. Ressalta-se que a referida instituição trabalho substitutivo dos hospitais psiquiátricos no Brasil, tem o escopo de atender crianças e jovens com transtornos mental, funcionando como porta de entrada para as questões relativas a saúde mental, desenvolvida por uma equipe multiprofissional.

\section{Objetivo da Pesquisa:}

Objetivo Primário:

1) Avaliar os efeitos de um programa de intervenção em Psicomotricidade Relacional sobre o comportamento da criança com autismo no que diz respeito à evolução das relações afetivas, faixa etária dos quatro anos no contato com o objeto, com o psicomotricista e com seus pares na evolução do setting. Objetivos Secundários:

1) Observar mudanças na forma com a criança se posiciona durante as sessões de psicomotricidade relacional: na relação da criança com o adulto;

2) Identificar as evoluções de uma sessão para outra no contato com o objeto e com seus pares.

\section{Avaliação dos Riscos e Benefícios:}

Riscos:

A estrutura das intervenções da Psicomotricidade Relacional oferece o minimo de risco aos participantes, uma vez que o risco estar condicionado ao ato de brincar, como: o correr, o jogar, o puxar, o girar, o pular. Diante de tal assertiva, a criança poderá cair e machuca-se, mas que faz parte do seu próprio desenvolvimento cognitivo, porque através do brincar os seres estruturam os seus âmbito da instituição CAPSI por Educadores Físicos, conduzido pelo especialista na área da Psicomotricidade Relacional. A proposta da intervenção psicomotora tem o escopo de desenvolver um trabalho com o amparo metodológico nos estudos de André Lapierre e Aucouturier (2004). Diante do exposto, procura-se descobrir de que forma as sessões de psicomotricidade relacional pode contribuir como método alternativo na educação sócio familiar da criança com autismo, na faixa etária dos quatro anos de idade, observando a relação com os objetos transicionais, relação com o psicomotricista e com seus pares na evolução do setting no âmbito do Centro de Apoio caps 1.

,

Endereço: Av. Senador Salgado Filho, 3000 Bairro: Lagoa Nova UF: RN Município: NATAL CEP: $59.078-970$ Telefone: (84)3215-3135 E-mail: cepufrn@reitoria.ufm.br 


\section{UNIVERSIDADE FEDERAL DO RIO GRANDE DO NORTE / UFRN CAMPUS CENTRAL}

Continuação do Parecer: 1.131.835

Beneficios:

Nesta configuração a participação das atividades será significativa, não excluindo a criança do grupo,promovendo o contato, as sessões oferecem os objetos transicionais que dão o apoio nas relações com os demais. O contato com o psicomotricista cria um elo de confiança, representando muita das vezes à figura paterna ou materna. A condução das intervenções abrirá um caminho para a socialização do individuo, como também trará beneficios inerentes ao próprio desenvolvimento humano que tratam das ações funcionais de estabilidade, locomoção, e de controle de objetos os quais são praticadas em qualquer contexto da vida diária.

Comentários e Considerações sobre a Pesquisa:

O projeto de pesquisa busca interpretar as relações afetivas nas sessões de Psicomotricidade Relacional. Configura-se um estudo de caso interpretativo, de cunho qualitativo, com uma criança autista observando as mudanças na forma com a criança se posiciona durante as sessões, na relação da criança com o adulto, especialmente no que diz respeito à evolução das relações afetivas, no contato com o objeto, com o psicomotricista e com seus pares na evolução do setting. A hipótese a ser testada é se o programa de Intervenção da Psicomotricidade Relacional contribui no desenvolvimento das relações afetivas de crianças com autismo infantil. Os autores esperam como resultado a mudança no comportamento da criança com autismo no que diz respeito à evolução das relações afetivas, e se o método das sessões de Psicomotricidade Relacional contribuem como método alternativo na educação sócio familiar da criança com autismo. O projeto está bem fundamentado no que se refere ao referencial teórico metodológico e é passivel de execução.

\section{Considerações sobre os Termos de apresentação obrigatória:}

Os termos de apresentação obrigatória estão adequados para o tipo de pesquisa.

\section{Conclusões ou Pendências e Lista de Inadequaçōes:}

Após análise ética e científica da carta resposta às pendências, o CEP Central/UFRN verificou que as pendências observadas no Parecer Consubstanciado $n .^{\circ} 1.098 .975$, datado de 29/05/2015, foram devidamente esclarecidas na atual versão do protocolo de pesquisa. Diante do exposto, o protocolo está APROVADO.

Situação do Parecer:

Aprovado

Endereço: Av. Senador Salgado Filho, 3000 Bairro: Lagoa Nova UF: RN Municipio: NATAL

Telefone: (84)3215-3135 CEP: $\quad 59.078-970$ ,

E-mail: cepufm@reitoria.ufm.br 


\section{UNIVERSIDADE FEDERAL DO \\ RIO GRANDE DO NORTE / \\ UFRN CAMPUS CENTRAL

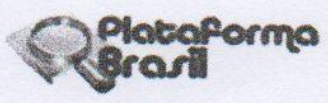

Continuaçăo do Parecer. 1.131.835

Endereço: Av. Senador Salgado Filho, 3000

Bairro: Lagoa Nova

UF: RN Municipio: NATAL

Telefone: (84)3215-3135
CEP: $59.078-970$

E-mail: cepufm@reitoria.ufm.br 